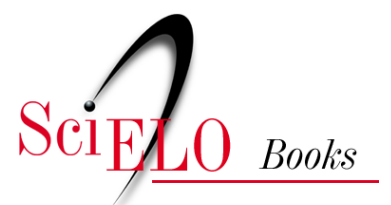

\title{
3. Educação alimentar ação político-pedagógica do mal de fome (1940-1946)
}

\author{
Eronides da Silva Lima
}

\section{SciELO Books / SciELO Livros / SciELO Libros}

LIMA, E.S. Educação alimentar ação político-pedagógica do mal de fome (1940-1946). In: Mal de Fome e não de raça: gênese, constituição e ação política da educação alimentar. Brasil, 1934-1946 [online]. Rio de Janeiro: Editora FIOCRUZ, 2000, pp. 149-258. ISBN: 978-85-7541-611-2. Available from: doi: $10.7476 / 9788575416112.0006$. Also available in ePUB from: http://books.scielo.org/id/xxmyz/epub/lima-9788575416112.epub.

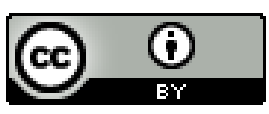

All the contents of this work, except where otherwise noted, is licensed under a Creative Commons Attribution 4.0 International license.

Todo o conteúdo deste trabalho, exceto quando houver ressalva, é publicado sob a licença $\underline{\text { Creative Commons }}$ Atribição 4.0. 


\section{EDUCAÇÃO ALIMENTAR: AÇÃO POLÍTICO-PEDAGÓGICA DO MAL DE FOME (1940-1946)}

O período de 1940 a 1946 foi caracterizado por uma produção centrada no processo de reordenação do conhecimento anteriormente produzido, na perspectiva da síntese e definição dos marcos conceituais e disciplinares da ciência da nutrição, procedendo ao reconhecimento operatório do objeto e do método pelo qual a educação alimentar deveria se individualizar. Isso implicava, também, o reconhecimento por parte dos intelectuais, dos precursores desse campo, ao tempo em que se reconheciam como grupo fundador. Tal estatuto afirmava uma identidade coletiva nesse processo de produção intelectual num momento em que se demarcavam fronteiras entre saberes que permeavam o sistema universitário emergente. Significa dizer que, no contexto desse tempo histórico, os intelectuais mantiveram em pauta os temas fisiológicos, eugênicos, higiênicos e sociais da alimentação, aprimorando-os por uma ótica diferente do período anterior (1934 a 1939), na medida em que, ao reordenar esse conhecimento, definiam os contornos terminológicos e conceituais de uma linguagem científica particular, cuja disciplinaridade operava com a substituição do universo do senso comum partilhado no cotidiano. Assim, como será visto, não estava mais em questão a delimitação do problema social significativo que motivou os estudos sobre alimentação, nem a formulação de uma tese central a ser demonstrada, mas, principalmente, a sistematização dos elementos de ruptura e continuidade estabelecidos nesse processo.

A título de exemplo, o livro de Veloso (1940), Alimentação, marca bem essa virada nos rumos da produção, apontando novos elementos para reflexão. Trata-se do primeiro livro didático destinado a Escolas Normais e Faculdades, organizado de acordo com os cursos oficiais, fato que o distingue da produção anterior, tanto na estrutura quanto no modo de abordagem. Os temas fisiológicos, eugênicos, higiênicos e sociais estiveram dispostos em pontos específicos de estudo na perspectiva de sistematização do conhecimento anteriormente produzido, de 
modo a atender a emergência do ensino da nutrição. De fato, emergia um novo tempo. O que antes assumia tom de denúncia sobre o atraso do Brasil em relação aos estudos científicos da alimentação e nutrição, bem como o descaso do Estado em matéria de política alimentar/educação alimentar, era substituído, na obra em apreço, pelo tom comemorativo de algo que se fazia nascer. Em 1940, o Estado já tomara para si a tarefa de realizar, na Capital Federal e por todos os estados da União, uma verdadeira política alimentar visando à infância e às classes operárias, orientada dentro de objetivos claros e definidos nos moldes cientificamente preconizados. Segundo Veloso (1940), o governo de Getúlio Vargas já havia encaminhado com nítida segurança a solução do problema, criando o salário mínimo e o Serviço de Alimentação da Previdência Social, e procurava, naquele momento, fundar o Instituto Nacional de Nutrição, visando, com tais medidas, a uma dupla finalidade: aumentar o poder aquisitivo do operário e ensiná-lo a comer. Foi assim, em torno destas duas demandas educação alimentar e política alimentar -, que os intelectuais reorientaram o conjunto da produção do período em foco, esboçando internamente quatro campos disciplinares de estudo e atuação: história e fisiologia, higiene alimentar (e, dentro dela, a educação alimentar), dietética e dietoterapia, e educação alimentar. Cumpre, então, destacar os termos, conceitos e pontos centrais que individualizavam esses campos disciplinares. Vale dizer também que, para além dos pontos teóricos desses campos, outra característica importante do período de 1940 a 1946 foi o aperfeiçoamento do enfoque técnico-instrumental.

\section{História e fisiologia: enaltecendo os precursores e reconhecendo o grupo fundador}

A confluência da história com a fisiologia coloca em evidência, num primeiro momento, os precursores da ciência da nutrição/educação alimentar, bem como o reconhecimento, entre os intelectuais, do surgimento, na década de 30, de um grupo de explicadores da situação alimentar brasileira que inaugurava um novo paradigma científico. Significa dizer que, se no período de 1934 a 1939 a fisiologia se configurava na história como ponto de partida para o conhecimento da situação alimentar brasileira, era no seu âmbito que precursores e fundadores haviam de ser reconhecidos e distinguidos no processo de constituição do campo científico da nutrição e, no seu interior, a educação alimentar. Assim, a forma pela qual os intelectuais dispuseram tais elementos históricos nas produções do período de 1940 a 1946 precisa ser mantida, dada a sua eficácia como plataforma conceitual justificadora na definição dos diversos campos disciplinares, em particular, o da fisiologia. 
Na visão de Veloso (1940), a alimentação humana tinha uma história, e a fisiologia era o seu desdobramento mais recente. Nessa perspectiva, os hábitos e práticas alimentares mudavam, passando por vários estágios evolutivos no processo civilizatório, cujas marcas ficaram à disposição da humanidade nas diversas formas de registro. Tal enfoque vinha aprimorar com maior riqueza de detalhes o processo evolutivo da alimentação, já descrito por Costa (1938), caracterizando os diferentes estágios nos quais se operaram mudanças no modo de o homem se alimentar.

Na trajetória descrita, Veloso (1940) assinalava que ainda não brotavam as primeiras civilizações e eis que já surgiam as diferenças de classes e, com elas, as diferenças de padrão de vida e de padrão de alimentação. Os três degraus do organismo social estavam lançados: pobreza, mediania e plutocracia. A alimentação, doravante, tinha de obedecer a esse imperativo sociológico - o dinheiro. Por toda a Idade Antiga, toda a Idade Média, toda a Idade Moderna e grande parte da Idade Contemporânea, pode-se dizer até a Grande Guerra de 1914, a alimentação humana se caracterizava, nas 'classes ricas', pelo luxo de requintes culinários capaz de corromper o mais abstêmio e pacato dos homens, transformando-o num terrível glutão: era a superalimentação, em suma, com todo o seu cortejo de malefícios; nas classes pobres, onde o dinheiro era sempre curto, era a escassez eterna de alimento, era o pauperismo de todos os tempos, que engendrava a subalimentação, traduzida, por sua vez, em sub-homens e subraças. Nas palavras desse autor, o meio termo eram as classes médias, justamente as menos prejudicadas, embora se alimentando ainda muito erroneamente, como era sabido.

Foi com o advento da Revolução Industrial, no século XIX, que começou a verdadeira 'revolução alimentar', com experiência de mais de meio século, $e$ que Veloso (1940) dizia ainda se estar vivendo. Para ele, conforme indicava Beltrami, nos países industriais que dirigiam o mundo, quase a metade das populações passou dos campos para as cidades, que assim cresciam em número de habitantes e em importância. Na França, por exemplo, o recenseamento de 1846, no começo da Revolução Industrial, dava apenas 8 milhões e 650 mil citadinos para 26 milhões 755 mil de rurais. Em 1891, já havia 14 milhões e 300 mil citadinos para 24 milhões de rurais, e, por fim, em 1931 o quadro já era inverso, isto é, 21 milhões 421 mil citadinos para 20 milhões 413 mil de rurais.

Com tal mudança, a alimentação sofreu, e ainda vinha sofrendo, modificações radicais: o fornecimento de alimentos frescos e sãos, de produção doméstica - granjas, pomares, quintais etc. -, foi quase substituído pelo fornecimento dos enlatados, salgados, secos e frigorificados, muitos já alterados 
e que provinham das mercearias, dos açougues e frigoríficos, dos mercados, das quitandas etc. "Por outro lado, as industrias de alimentos, com seus processos modernos, artificialisam, o termo deve ser êste, cada dia mais os nossos produtos comestíveis" (Veloso, 1940:16). Quanto a isso, para o autor, havia-se perdido a admirável sobriedade no comer e no viver dos antigos gregos; a sobriedade de que nos falavam também os Evangelhos e com a qual o próprio Cristo construiu grande parte de sua doutrina. Para desgraça e grande mal do Homo sapiens, tal doutrina não tinha sido compreendida e observada. A respeito de tamanha reviravolta, dizia McCollum (apud Veloso, 1940:16):

Será surpresa para muitos saber que todos os norte-americanos e certos europeus, teem, nos ultimos 50 ou 75 anos, experimentado um novo sistema de regime alimentar que representa uma mudança radical em relação aos regimes até então conhecidos na história humana. Anteriormente a 1879 ninguem na Europa ou na América comia farinhas de cereais beneficiadas ou incompletas. Foi nêsse ano que se inventou o moinho de rôlo para fabrico da farinha de trigo branca. Agora, raramente vemos a farinha de trigo completo ou o fubá de milho completo usado no preparo dos alimentos humanos, No decurso de um século, o consumo de açucar aumentou de 9 à 10 vezes. Por volta de 1800 o consumo de açucar por pessoa e por ano era de 5 quilos, enquanto que agora sobe aproximadamente a 45 quilos.

Nessa versão, além das inúmeras modificações que a máquina e a cidade introduziram no regime alimentar do homem contemporâneo - a vida agitada que ele levava, a vida relâmpago que engendraram como condição do progresso - criou-se algo novo chamado taquifagia. Os homens mais civilizados da atualidade são geralmente taquífagos, isto é, comem com uma rapidez e velocidade incríveis. E os alimentos mal mastigados são mal digeridos e malabsorvidos e, quando absorvidos, mal-assimilados. As conseqüências biológicas e sociais decorrentes de tal transformação já se faziam sentir, a despeito dos pouquíssimos anos que a vivíamos.

É evidente que tal demarcação de fronteiras alimentares entre classes ricas e classes pobres foi uma tônica comum no conjunto da produção a partir do período de 1934 a 1939, estendendo-se ao período em foco, o que reflete um modo particular e articulado de conceber não somente o surgimento dessas classes no Brasil, como também a existência de dois elementos que as distinguia e de certa forma as individualizava: o plano da produção e o do consumo em relação íntima com o modo de se alimentar, sendo o dinheiro (e não as relações) o traço distintivo entre as classes referidas. A exposição de Veloso (1940) anteriormente mencionada é ilustrativa desse enfoque, na medida em que trata de simples descrições de experiências e características alimentares das classes, 
em geral, que conduzem muito mais a estereótipos generalizantes do que à compreensão das estruturas sociais concretas nas quais as classes se constituíram, dos seus dinamismos e processos de mudança. $O$ traço comum desse enfoque acabava sempre recaindo na Revolução Industrial do século XVIII como fator de expansão demográfica rural-urbano diante de uma nova divisão do trabalho, e nos processos tecnológicos nos quais se afirmaram as referidas classes e, por conseguinte, nas mudanças no modo de se alimentar, impingindo novos padrões dietéticos diferençados. Com isso, o termo classe não era posto como categoria analítica historicamente explicativa. Segundo Stavenhagen (1966:138):

para a escola marxista, as classes constituem um fenômeno quase universal, característico de qualquer sociedade baseada na exploração duma parte da população por outra, ou seja, tanto do escravismo, como do feudalismo e do capitalismo (...) O industrialismo é um tipo de produção material, não um tipo de estrutura sócio-econômica. É o resultado do progresso técnico da humanidade, não das relações específicas que se estabelecem entre os homens tendo por base determinadas forças de produção. Se bem que a produção industrial só possa existir quando se apresentem certas formas de organização sócio-econômicas, é certo também que ela constitui apenas um dos elementos desta. As classes sociais não são a expressão do tipo de produção material dominante na sociedade, mas a expressão das relações de produção dominantes da sociedade.

Em verdade, para Veloso (1940), a história também criou a fisiologia. Nessa perspectiva, ele recuperou de forma bastante rápida as idéias dos pensadores que antecederam as descobertas de Lavoisier (que viveu de 1743 a 1794). A Idade Antiga e a Idade Média, que se findara no ano de 1543, haviam fornecido elementos rudimentares à configuração de uma ciência da nutrição, a partir de Hipócrates, o 'pai da medicina', que afirmava que não se podia viver sem respirar, nem se vivia sem comer nem beber; de Aristóteles, que afirmava que a urina e os excrementos representavam as partes não-utilizáveis dos alimentos no organismo; e de Galeno, que defendia a idéia da existência de uma única substância nutritiva distribuída por todos os alimentos de que se utilizavam os homens e animais na sua alimentação.

Nesse ponto, faz-se importante a advertência de Le Goff (1994:23-24), pela qual:

Para restituírem à história o seu movimento verdadeiro, seria muito mais vantajoso lerem-na, como dizia Maitland, 'ao contrário' (...) Daí o interesse de 'um método prudentemente regressivo' (...). Prudentemente, isto é, que não transporte ingenuamente o presente para o passado e que não procure por outras vias um trajeto linear que seria tão ilusório como o sentido contrário. Há 
rupturas e descontinuidades inultrapassáveis quer num sentido quer noutro (...) Esta longa duração do passado não deve, no entanto, impedir o historiador de se distanciar do passado, uma distância reverente, necessária para o respeitar e evitar o anacronismo (...) este passado se torna objeto da história, por uma reconstrução incessantemente reposta em causa.

Dito isso, o estudo de Sigerist (1987) é sugestivo, quando assinala que levou muito tempo para a ciência médica liberar-se da influência de Galeno. A teoria dos quatro humores (o sangue, a flema, a bilis amarela e a bilis negra) correspondia à idéia de Empédocles de que quatro elementos constituíam o mundo: ar, água, terra, fogo. Tanto os humores como os elementos estavam dotados de qualidades elementares: calor, frio, umidade, secura. A perfeita saúde prevalecia quando os humores se encontravam corretamente equilibrados com respeito ao temperamento, ao vigor $e$ às quantidades, e quando sua mistura era perfeita. A enfermidade resultava do excesso ou do defeito desses humores, ou do isolamento de um deles com relação ao resto. O objetivo da higiene, em conseqüência, devia ser a manutenção do equilibrio normal entre os humores e suas qualidades mediante a prescrição de doses adequadas de alimento, bebida, sono, vigilia, atividade sexual, exercício, massagens etc. Tal teoria regeu a medicina durante mais de dois mil anos e ainda é vigente, hoje, no Oriente. Ao aplicar o princípio de contraria contrariis para curar uma enfermidade fria com medicamentos quentes, ou uma condição úmida com exercícios secos, a terapia chegava a ser 'quase' matemática. Tais princípios foram aplicados por Galeno para a conservação da saúde. Assim, a eleição dos alimentos tinha uma importância máxima; a arte da nutrição tinha-se desenvolvido altamente, em forma empírica, desde os tempos de Hipócrates. Uma nutrição correta era um elemento essencial para a saúde segundo o critério dos médicos hipocráticos; vários trabalhos da coleção hipocrática estavam dedicados ao efeito de determinadas substâncias alimentícias sobre a saúde ou a enfermidades corporais. Galeno, por sua parte, escreveu um tratado em particular acerca das qualidades dos alimentos. Nele, elaborava listas com diversos vegetais, frutas, carnes, pães, bebidas etc. e considerava sua influência sobre a saúde. Nisso prevalecia o princípio da moderação com respeito à natureza dos comestiveis e das bebidas, sua quantidade, qualidade e virtudes, a fim de não se ingerir em excesso nem demasiado pouco senão exclusivamente o que o corpo digerisse, distribuísse e utilizasse nutritivamente em forma adequada, sobretudo se necessitava prover de simetria as partes em crescimento, alijando-se de toda demasia e de toda insuficiência.

Era então essa admirável sobriedade no comer e no viver dos antigos gregos, a sobriedade de que nos falavam os Evangelhos, que Veloso (1940) dizia ter sido perdida com a Revolução Industrial. Em verdade, tendo por base sua narrativa 
histórica, o autor consolidava e reordenava, para fins do ensino da nutrição, a visão de uma tendência majoritária dos intelectuais, já esboçada no período anterior (1934 a 1939), segundo a qual a química, que havia nascido no século XVIII, recebia de Lavoisier um impulso considerável e, com ela, também a alimentação, inaugurando assim a primeira fase científica da nutrição. Para Veloso (1940:19), a explicação de que a respiração era uma verdadeira oxigenação constituía um fato sem precedentes e único no estudo dos fenômenos biológicos naquela época, porque "pela primeira vez, se atribuía a uma função vital a natureza de um verdadeiro fenômeno químico, análogo àqueles que se passavam no reino dos corpos inanimados".

Devia-se a Voit e Rubner, Chaveau, Zuntz, Tigerstedt, Magnus Levy, Atwater, Bryant, Von Noorden, DuBois, Benedict, Carpenter, Lefèvre e outros a extensão e a aplicação dos estudos do metabolismo e da nutrição no terreno da ciência e da prática, no começo do século XX, segundo os princípios da bioenergética que surgia. Todos os alimentos, pelas reações por que passavam no interior do organismo, desprendiam a energia neles armazenada desde a sua formação. Por fim, nessa visão, se atingia a etapa final da história científica da alimentação, com a descọberta das vitaminas, por volta de 1911, por Funk, e que vinha mostrar que havia em muitos alimentos determinados princípios que, embora não fornecendo nem calor nem substâncias plásticas, exerciam, contudo, poderosa influência sobre os fenômenos biológicos da mais alta significação (Veloso, 1940).

Foi nesse percurso da história que esse autor situou os precursores da ciência da nutrição no Brasil, evidenciando que o estudo da alimentação entre nós não era tão recente quanto se pensava. Já em 1865 o higienista Sousa Costa, em trabalho intitulado 'Qual a alimentação de que usa a classe pobre no Rio de Janeiro e a sua influência sobre a mesmá classe', estudava o problema alimentar próprio daqui, mostrando ser a alimentação do brasileiro insuficiente em matérias protéicas e dizia que: "A alimentação é pouco 'animalisada', porque o feijão, o pão, a farinha de mandioca, o arroz, a batata, o cará, o aipim, etc., que constituiam a base dessa alimentação, eram 'vegetais'" (Costa apud Veloso, 1940:22).

Outro trabalho daquela época apontado foi o de Azevedo Pimentel, 'Subsídios para a higiene do Rio de Janeiro', em que o autor estudava os defeitos da alimentação da criança, do adulto e das nossas classes pobres que, naquele tempo, e, talvez muito antes, já viviam em subalimentação. Sob esse ângulo, para Veloso (1940), era Eduardo de Magalhães, sem nenhum favor, o precursor de uma série de importantes descobertas e estudos relacionados à alimentação, não só no Brasil como também em todo o mundo, por meio da obra intitulada Higiene Alimentar, publicada em 1907. Esse autor transcrevia diversos pontos da obra de Magalhães, entre os quais, no Brasil: 
O que sobra nas classes elevadas falta nas inferiores, ou, como disse Raspail, a 'indigestão dos ricos vinga a fome dos pobres'. A frequência das alterações gástricas, as moléstias do fígado, as desordens intestinais, as enfermidades dos rins, a síncope cardíaca, o aneurisma, a apoplexia e outras mais, eram o epílogo de tanto abuso e de tanta sensualidade. (Magalhães apud Veloso, 1940:23)

Renato de Souza Lopes foi também por ele considerado um pioneiro dessa primeira fase, tendo, no ano de 1909, escrito um interessante trabalho intitulado Regime Alimentar nos Climas Tropicais. Nesse ponto, Veloso (1940) afirmava que, para o nosso grande mal, as palavras esclarecidas e os ensinamentos sábios desses pesquisadores não frutificaram entre nós, pelo menos por longos anos. E o problema alimentar, desde aquela época até há poucos anos, havia passado completamente esquecido e ignorado dos governos, dos nossos técnicos e especialistas:

Somente agora, de 1930 para cá, é que a nossa realidade alimentar começa a preocupar a atenção de um pequeno grupo de estudiosos. Surgem então as primeiras obras especialisadas no assunto, de Josué de Castro, a que se seguem os trabalhos e depoimentos insuspeitos de Afrânio Peixoto, Anes Dias, Hélion Póvoa, Gilberto Freyre, Roquete Pinto, A. Osorio de Almeida, Renato Sousa Lopes, Sinval Lins, Paula Sousa, Araujo Lima, Alfredo de Andrade, Sebastião Barroso, Alexandre Moscoso, Henrique Roxo, Moura Campos, Castro Barreto, Paula Rodrigues, Almeida Junior, J. de Barros Barreto, Talino Botelho, Couto e Silva, Peregrino Junior, Rui Coutinho, Messias do Carmo, Dante Costa, Salvio de Mendonça, Robalinho Cavalcantti, Rubens de Siqueira, Pompeu do Amaral, Carlos Sá, Rubem Descarte de Paula, Celina M. Passos, Helio Luz, Tomaz de Figueiredo Mendes, Costa Couto, Ulhôa Cintra, Maurício Ielpo, Deodato de Morais e outros - mostrando todos eles as 'péssimas e deficiêntes condições da alimentação do nosso povo'. (Veloso, 1940:24)

Nessa visão, a caracterização do processo de constituição da ciência da nutrição e, no seu âmbito, a educação alimentar, como um fato histórico qualificado, incidindo sobre outros acontecimentos, remetia à identificação dos sujeitos cognoscentes e do objeto construído. Para Schaff (1995:234):

Nenhum acontecimento se destaca por si mesmo dos outros acontecimentos, continua a ser simplesmente um acontecimento no meio dos outros. A 'importância', o 'significado' de um acontecimento é uma qualificação valorizante que precisa da existência não só do objeto valorizado, mas também do sujeito valorizador.

Nessa perspectiva, cada fato histórico, mesmo o mais primário, é composto. Contém em si mesmo a possibilidade de contradições e de identidades. Significa com isto sublinhar a dinâmica dos acontecimentos, a sua tendência para a interdependência e a interferência da diferenciação e da integração. Veloso (1940), 
ao reconhecer, no âmbito da história da ciência, o surgimento de um grupo que desvendava pela fisiologia as incógnitas da situação alimentar brasileira, assinalava que a produção em foco trazia as marcas dos sujeitos explicadores. Para além dos limites temporais e substanciais dessa produção, havia, em todas as suas fases, a intervenção de um grupo, das suas diversas determinações e, sobretudo, do paradigma em torno do qual os sujeitos operavam. Afirmando a existência de uma identidade coletiva, o autor reconhecia os verdadeiros explicadores do fenômeno alimentar na década de 30, por uma produção que, não obstante as diferenciações nos enfoques adotados, era marcada por uma tese unitária e a perspectiva de construção de um método único que assegurasse a individualidade da educação alimentar em meio à multiplicidade de métodos que permeavam os estudos parciais dos precursores desse campo, sem desconhecer, contudo, a sua importância. Era por referência ao método que o problema alimentar podia ser visto em toda a sua extensão, causalidade e finalidade na constituição do novo paradigma proposto. Como será visto, para situar o grupo fundador na história, os intelectuais buscavam destacar as relações do desenvolvimento das suas produções com os outros acontecimentos, processos, produtos, no contexto dos quais essas produções se manifestavam e se tornavam inteligíveis - com a introdução, no cenário científico, econômico, ideológico, político e cultural da sua épocá, de um novo instrumento conceitual. A definição, no interior da ciência da nutrição em formação, dos diversos campos disciplinares, incluindo a educação alimentar, no período de 1940 a 1946, vinha assinalar tal inteligibilidade.

Perseguindo tal objetivo, Veloso (1940) delineou os vários ângulos que deveriam orientar os estudos da alimentação e nutrição: o individual, o eugênico, o social e o econômico.

O ângulo individual levava ao estudo das necessidades fisiológicas alimentares que tinha o homem, para assegurar o seu crescimento, a sua conservação, o seu trabalho, devendo ser examinadas sob vários aspectos:

- gastronômico, que orientava e dirigia a verdadeira culinária fundada nas leis da cozinha dietética - dietética;

- higiênico, que fornecia ao homem regras e os preceitos da boa alimentação, dando os meios de evitar as moléstias da nutrição - higiene alimentar;

- médico, que cuidava da dietética indicada às diferentes doenças, com que se deparava a clínica diária - nutrição clínica;

- moral, que mandava substituir o aforismo dos antigos - 'viver para comer' pelo 'comer para viver', ou então 'comer bem para viver bem'; $e$ 
- eugênico, que se preocupava com o aperfeiçoamento da raça, tornando-a 'mais robusta e mais forte, mais bela e mais capaz de trabalhar e produzir'. A noção de região perpassava todos os ângulos, tomando por base o alimento como traço de união fisiológica entre o meio e o homem, pois era por meio dele que o homem assimilava e vivia o meio e que o meio participava do homem. Reafirmava, assim, o autor: "É este a meu ver, o verdadeiro conceito bio-sociológico de alimento" (Veloso, 1940:35).

Nesse enfoque, pelo ângulo social, o problema assumia interesse, pois era fato conhecido a relação estreita entre a boa alimentação e o aumento da natalidade entre certas raças. Igualmente a mortalidade precoce em várias idades, a longevidade e a saúde estavam na dependência do fator alimentar.

O ângulo econômico do problema também era vasto. Envolvia a questão 'obtenção' e a questão 'utilização' dos alimentos. Era necessário "estimar o gasto com o consumo mínimo de subsistência alimentar, que dê efeito útil máximo e um rendimento igualmente máximo, quer na alimentação das coletividades, quer ao indivíduo" (Veloso, 1940:40). A importância do estudo da alimentação estava na possibilidade de abranger todos esses aspectos complexos, cujo fim era "a felicidade individual, a felicidade coletiva, o amor entre os homens. Porque da má alimentação surge a má saúde; da má saúde, a má vida; da má vida, a miseria, a dôr e o sofrimento" (Veloso, 1940:33).

É digno de nota que, nessa abordagem, era a higiene alimentar a razão de ser da ciência da nutrição, pois, segundo o autor em foco, essa sua obra buscava a sistematização de uma série de conhecimentos que, obedecendo a um plano previamente traçado, tinha por principal escopo valorizar o capital humano, valorização integral do ponto de vista biológico, social e econômico. Para isso, a alimentação e a nutrição haviam saído da mera especulação teórica para o vasto campo da experimentação, da alimentação comparada, da observação in loco e da prática, surgindo as bases seguras para um nova conduta científica e social relativa ao problema da alimentação em todo o mundo.

Sob esse aspecto, Veloso (1940) sistematizava os princípios fisiológicos da alimentação para efeito do ensino da nutrição, iniciando pela definição precisa dos termos alimentação - metabolismo - nutrição. Segundo ele, era curioso observar a preferência que tinham as escolas de diferentes países por essa ou aquela terminologia. Na América do Norte, por exemplo, o termo nutrição era correntemente empregado pelos autores com significação incomparavelmente mais ampla do que o termo alimentação. Tudo ali era nutrition, vindo depois a palavra feeding. O termo fez escola e havia de ser assim até o fim. Isso era o que se depreendia ao mais rápido exame dos títulos dos livros que nos vinham de lá. 
Na Alemanha, a palavra Ernâhrung significava, ao mesmo tempo, nutrição e alimentação. Na França e na Itália, os termos pareciam se equilibrar perfeitamente. Já na Argentina e no Brasil, em especial, a palavra alimentação era a preferida. Segundo Veloso, todos os livros aqui publicados sobre o assunto, nada menos de uns 20 , traziam invariavelmente na sua capa o termo alimentação, com o mesmo sentido e extensão com que os norte-americanos usavam a palavra nutrição.

Em verdade, os resultados do rastreamento dessa produção coincidem com a constatação de Veloso (1940), pois, dos 38 títulos que encontrou-se, apenas um era designado pelo termo nutrição, sendo os demais designados pelo termo alimentação. Disso decorre também o uso da terminologia educação alimentar por todos os autores (e não a terminologia educação nutricional, usada atualmente) no processo de constituição desse campo, o que remete à discussão se de fato é possível uma educação nutricional, ou se o sentido e todo o alcance dessa modalidade educativa está mesmo no termo educação alimentar tal como foi proposto em sua origem.

Quanto a isso, é esclarecedor o procedimento adotado por Veloso (1940:29), ao definir o termo nutrição como "troca de matérias, depois de convenientemente transformadas, que se estabelece entre o meio interior e os elementos anatômicos". Enquanto isso, o fenômeno da 'alimentação', mais vasto e mais amplo, foi definido como "o conjunto de atos ou fenômenos com os quais o ser humano apreende os alimentos e os prepara - 'cozinha culinária'; come-os - 'mastigação', 'insalivação' (...) e 'deglutição'; digere-os - digestão; absorve-os - 'absorção'; metaboliza-os 'metabolismo' e finalmente incorpora às células e tecidos do organismo - nutrição" (Veloso, 1940:29). Nessa visão a nutrição constituía, pois, a fase última e útil da alimentação. Quanto a isso, a ciência da alimentação era a aplicação racional das leis da nutrição ao desenvolvimento do indivíduo, à manutenção de suas funções orgânicas, à produção do trabalho, visando tudo isso à conservação da família, da raça e da espécie. Era por esse ângulo que o mencionado autor diferençava o uso do termo alimentação, usado por aqui, do termo nutrição usado por Mc Lester, da escola americana, por exemplo: "nutrição é a reunião total dos processos por meio dos quais o organismo vivo recebe e utiliza os materiais necessários à manutenção da vida" (Veloso, 1940:29). O termo metabolismo já não trazia tanta divergência. A maioria dos cientistas nacionais e estrangeiros empregavam-no com um sentido mais ou menos equivalente, embora em permanente conflito com a palavra nutrição.

Isso remetia, também, à própria definição do conceito de alimento, que Veloso (1940:34) preferiu iniciar pelo postulado de que o organismo humano, a máquina viva, não se furtava à lei geral da biologia - lei da renovação orgânica 
ou lei da alimentação: "A atividade vital só poderá manter-se com a condição do organismo se alimentar". Nesse aspecto, ele revelava a pouca exatidão da relação 'homem máquina' e 'alimento combustível' corrente nos livros de alimentação, com base nos princípios da bioenergética estabelecidos por Lavoisier e seus seguidores. Explicava Veloso (1940) que, nessa visão, para o trabalho incessante e o aperfeiçoamento da renovação orgânica, a máquina viva, como qualquer máquina morta, necessitava de combustível. E esse combustível era o alimento. Para esse autor havia, no entanto, radical diferença entre combustível e alimento, entre máquina morta e máquina viva. Na máquina mecânica, o combustível desenvolvia energia que se traduzia em força, em trabalho, em movimento, mas as peças se gastavam e só se regeneravam por conserto ou substituição, com o auxílio de um terceiro; na máquina orgânica, porém, além da energia e do calor resultantes, o alimento repunha os gastos ocorridos e refazia as células, tecidos e órgãos, de modo que esses se renovavam automaticamente, por si mesmos. Constituía isso uma das maravilhas da vida. Assim:

O organismo não é uma 'máquina térmica', isto é, uma máquina onde o calor cria outras formas de energia, e a comparação corrente, que vem desde Lavoisier, entre alimento e combustivel é pouco exata, porque o organismo não emprega para as suas atividades o calor de combustão dos próprios alimentos, mas utiliza diretamente a energia química neles contida e no $\mathrm{O}_{2}$, energia química que por comodidade (eu diria antes - por necessidade) é medida calorimetricamente, mas que no corpo realiza outras transformações: distribuese entre soluções de concentrações diversas, em sistemas complexos; transformase abundantemente em energias de superfícies que, por sua vez, criam forças tensoras e atrativas (adsorção); estabelece potenciais de membranas e finalmente reflue irreversivelmente no mar morto da energia menos nobre, a mais degradada, que é a energia térmica, e sob esta forma, se não ha trabalho externo, abandona o organismo. (Veloso, 1940:35)

Com isso, se afirmava o primeiro elemento de ruptura concebido de forma articulada e unitária: a reinterpretação das leis da bioenergética de Lavoisier, dada a sua baixa eficácia explicativa, na medida em que reduzia o fenômeno vital à sua dimensão quantitativa, enquanto subordinava o homem às leis gerais da natureza. No Brasil da época em foco, estava em debate o valor do capital humano, pois tudo dependia não só da quantidade de braços, mas também da qualidade:

o problema do homem é duplamente grave e urgente - porque é a um só tempo quantitativo e qualitativo. Isto é, precisamos de povoar o país, aumentar a sua densidade demográfica, aproveitá-lo economicamente; mas precisamos também, e sobretudo, de melhorar a qualidade do homem brasileiro, estimulando suas aptidões biológicas, o seu rendimento de trabalho, o seu valor vital. Penso ainda com Roquete Pinto que, no Brasil, o essencial não é o 
aumento global da população, mas o aumento da eficácia do homem que trabalha. E um dos meios mais idoneos para isso, senão o mais eficaz, é resolver quanto antes o problema da alimentação do brasileiro. Sem resolver imediatamente êste problema, não poderemos melhorar o valor humano da nossa gente. (Peregrino Júnior, 1942:91-92)

Afirmando a visão de que o alimento era o traço de união entre o homem e o meio, Veloso (1940:35) entendia por alimento "toda e qualquer substância orgânica ou mineral, que introduzida no organismo em proporções convenientes é capaz de assegurar-lhe o desenvolvimento e a conservação normais no meio em que vive". Logo, o homem não podia ser concebido como máquina, mas como um ser social, e não deterministicamente subordinado às leis da natureza. Assim, na visão do autor, para que um corpo qualquer de natureza animal, vegetal ou mineral pudesse constituir propriamente alimento, precisava:

- ser comível - estar em condições de ser ingerido;

- ser digerível - transformável no tubo digestivo, de modo a ser absorvido; e

- ser nutriente - constituir-se dentro do organismo parte componente de órgãos e tecidos.

Essa era a verdadeira plástica função do alimento. Além disso, havia que considerar o poder energético do alimento. Os alimentos eram fontes de energia química potencial que o sol lhes fornecia. O organismo, no seu complexo trabalho metabólico, transformava toda a energia potencial em energia atual, isto é, movimento e trabalho (energia mecânica); calor (energia térmica); eletricidade, energia magnética, tudo isso que, reunido no organismo, determinava, como etapa final, a energia biológica, que era a vida. Esta concepção se ampliou depois que a bioquímica, de um lado, e os médicos, do outro, se deram as mãos para o estudo de certos fenômenos da nutrologia, surgindo uma nova função para os alimentos - a reguladora e protetora - que se devia aos chamados fatores acessórios da alimentação ou, simplesmente, vitaminas. Assim, os alimentos também não podiam ser concebidos como combustíveis, mas desempenhavam no organismo três diferentes papéis fisiológicos: 'papel energético', que só tinha valor quantitativo, 'papel plástico' e 'papel regulador', ambos com valores qualitativos específicos.

Por essa ótica, o aspecto bromatológico do alimento adquiria expressão, no âmbito da fisiologia, dado que o estudo dos alimentos pertenciam, em verdade, a várias disciplinas ou ciências: à biologia, à fisiologia, à química orgânica e inorgânica, à higiene e, particularmente, à bromatologia, palavra derivada do grego bromatos, que significa alimento, e logos, trabalho. Na sociedade, a bromatologia, mediante seus inúmeros processos de estudo e análise dos 
alimentos, a ponto de se constituir uma especialidade à parte, nos cursos de saúde pública e de higiene, devia orientar as condições em que se deviam apresentar ao consumo os alimentos, examinando-lhes o teor nutritivo, a pureza, as falsificações e outras fraudes, as deteriorações, as incompatibilidades etc. Era com tal finalidade que Alfredo A. de Andrade, do Laboratório Bromatológico de Saúde Pública, procedia à classificação do ponto de vista químico dos alimentos do País, fornecendo uma tabela na qual constava o teor de proteínas, gorduras, hidratos de carbono, vitaminas, água, sais minerais e oxigênio. Desse modo, os alimentos eram classificados em inorgânicos - os sais minerais - e orgânicos - alimentos animais e vegetais.

Por referência a essas propriedades, Veloso (1940:62) entendia por "valor 'nutritivo' 'dos alimentos' a capacidade que têm estes, em maior ou menor grau, de atender às 'necessidades fisiológicas' do organismo do duplo ponto de vista "material e calórico'". Isso estava em relação com:

- a composição química do alimento; $e$

- o seu grau de digestibilidade e o seu coeficiente de absorção pelos intestinos.

Nesse aspecto, foram definidas todas as fases da digestão dos alimentos e o processo de absorção dos nutrientes, bem como os mecanismos de excreção. Nessa visão, a fisiologia compreendia a biofísica e a bioquímica, tratando de toda sorte de transformações, reações e funções dos alimentos no organismo.

Posto isso, Veloso (1940) definia o metabolismo energético à luz de dois mecanismos: a energia calorífica para manutenção do calor animal e a energia mecânica para execução do trabalho fisiológico, considerando os fatores que alteravam a produção de calor. Nessa perspectiva, o autor passava em revista o metabolismo basal, admitindo que havia uma despesa e uma receita diárias de 2.800 a 3 mil calorias para um homem de estatura média, que se entregasse a um trabalho moderado.

O metabolismo basal foi definido, então, como uma constante fisiológica resultante apenas do funcionamento do protoplasma, do trabalho do coração, do trabalho dos rins, do trabalho dos músculos respiratórios, do trabalho de contração das fibras lisas do tubo digestivo e do tônus muscular, em outras palavras, a 'despesa de conservação' do organismo de Magnus Lévy. Assim, metabolismo basal era a quantidade de calorias produzidas por um indivíduo em uma hora e por metro quadrado de superfície corporal, estando em jejum de 12 horas pelo menos, deitado e em repouso absoluto, vestido e à temperatura ambiente de 16 a 18, conforme tabela construída por DuBois. Contudo, esse era o metabolismo de apenas uma hora e por metro quadrado de superfície corporal. Para se obter o Metabolismo Basal Total (MBT) do mesmo indivíduo, no espaço 
de um dia, bastava multiplicar o número de calorias produzidas em 1 hora por 24 horas, obtendo-se o total de calorias produzidas em 24 horas, e por metro quadrado de superfície corporal; multiplicava-se, em seguida, o produto encontrado pelos algarismos que correspondiam à superfície corporal total do indivíduo com o auxilio da tabela de DuBois, a qual estabelecia a cifra standard do metabolismo basal de adultos de climas frios e temperados, que era de 39,7 calorias por hora e metro quadrado de superfície corporal, para o homem, e 37 calorias para a mulher.

Veloso (1940) reiterava ainda que qualquer trabalho executado pelo organismo se acompanhava de gasto de energia equivalente à intensidade desse trabalho. O metabolismo de trabalho era a quantidade de calorias produzidas pelo indivíduo em uma hora e por metro quadrado de superfície corporal, além do metabolismo basal, estando o organismo em trabalho leve, mediano ou pesado. Era o metabolismo fora das condições chamadas basais. Entendia-se, por trabalho, todo e qualquer esforço desenvolvido pelo indivíduo que não está em repouso, desde o trabalho intelectual e o trabalho mínimo despendido com a mastigação dos alimentos, por exemplo (trabalho muscular levíssimo, este último), até o trabalho mais fatigante do lenhador, do quebrador de pedras, do soldado em campanha, do lutador de boxe, do corredor (trabalho muscular considerável ou muito intenso). A energia necessária à realização de qualquer trabalho era calculada em quilogrâmetro, isto é, a força capaz de elevar um quilo de peso a um metro de altura. Essa força correspondia ou era igual a 0,00234 centésimos da caloria, ou, então, uma caloria era produzida por 425 quilogrâmetros, o que vinha a ser a mesma coisa.

Dada a inexistência de dados sobre as despesas calóricas decorrentes do trabalho do nosso operário, uma vez que até a época não haviam sido feitas investigações nesse sentido, Veloso considerava que sempre seria necessário recorrer aos estudos estrangeiros para a determinação do padrão dietético brasileiro. A esse respeito, apresentava as cifras médias de despesa de trabalho estabelecidas pela Liga das Nações: trabalho leve (alfaiate, intelectual), 75 calorias por hora; trabalho muscular mediano (sapateiro, encanador), 75 a 140 calorias por hora; trabalho muscular intenso (carpinteiro), 150 a 300 calorias por hora; e trabalho muscular muito intenso (ferreiro, serrador de madeira), 300 ou mais calorias por hora. Assim, o conhecimento do metabolismo de trabalho era então de suma importância, pois "trabalho é, como todos sabem, capital, é dinheiro cujo rendimento maior ou menor está na dependência das possibilidades físicas do trabalhador, seja ele qual fôr" (Veloso, 1940:113). Portanto, um traço marcante desse processo definidor do campo disciplinar da fisiologia, no período de 1940 
a 1946, foi o detalhamento dos mecanismos do metabolismo das proteínas, dos hidratos de carbono, das gorduras, da água e sais minerais, e das vitaminas, desdobrados em vários pontos de estudo por Veloso (1940:primeira parte):

1Ponto - Histórico. Alimentação do homem neolítico. Alimentação do homem atual. História científica da alimentação. Alimentação no Brasil.

2. Ponto - Alimentação, metabolismo e nutrição. Importância do estudo da alimentação.

$3^{2}$ Ponto - Alimentos. Conceito, definição e classificação. Bromatologia. Composição dos alimentos. Valor nutritivo e utilização dos alimentos.

$4^{2}$ Ponto - Digestão. Suas diferentes fases. Digestão dos princípios imediatos proteínas, hidratos de carbôno, gorduras. Absorção. Nutrição. Secreção e excreção.

5o Ponto - Metabolismo energético. Calor animal. Fatores que alteram o calor animal. Ação dinâmica específica dos alimentos.

6o Ponto - (Continuação metabolismo energético) - Metabolismo basal ou mínimo. Sua determinação. Cifras normais do M. B. Fatores capazes de alterar o M. B. - idade, sexo, regime alimentar, estado fisiológico, clima.

7ํ Ponto - (Continuação metabolismo energético) - Metabolismo de trabalho.

8 Ponto - Metabolismo material. Mecanismo metabólico. Entradas e saidas globais. Órgãos do metabolismo. Leis gerais da alimentação - lei da isodinamia; lei do mínimo.

9o Ponto - (Continuação metabolismo material) - Metabolismo das proteínas. (Protídios) Papel do figado. Metabolismo dos protídios. Lei do mínimo proteico. Utilização das proteinas.

$10^{\circ}$ Ponto - (Continuação metabolismo material) - Metabolismo dos hidratos de carbôno no organismo. Metabolismo intermediário. Mínimo hidrocarbonado.

11ำ Ponto - (Continuação metabolismo material) - Metabolismo das gorduras. (Lipídios) Metabolismo intermediário. Mínimo de gorduras.

$12^{\circ}$ Ponto - (Continuação metabolismo material) - Metabolismo da água e dos sais minerais.

$13^{\circ}$ Ponto - As vitaminas. Histórico, definição, classificação. Mínimo de vitaminas.

140 Ponto - Estudo da vitamina A.

15 Ponto - Estudo do complexo B.

160 Ponto - Estudo da vitamina $C$.

17을 Ponto - Estudo da vitamina D.

$18^{\circ}$ Ponto - Estudo da vitamina E.

19. Ponto - Estudo da vitamina anti-pelagrosa. 
Não se conclua, com isso, que todos os intelectuais definiram o campo disciplinar da fisiologia com o nível de detalhamento de Veloso (1940), pois, se é possível localizar pontos significativos de aproximação entre eles, também são evidentes os pontos de distanciamento, não só de forma mas também de conteúdo. Na mesma trilha de Veloso (1940), Siqueira (1940), em seu livro Alimentação: questões brasileiras da atualidade, reuniu uma série de artigos sobre alimentação no Brasil, tendo por base a orientação que ele havia dado, em 1938, a um curso de aperfeiçoamento para médicos e doutorandos. No entanto, diferentemente, esse autor não esteve voltado para os estágios civilizadores que marcaram as etapas evolutivas da alimentação, alterando hábitos e práticas (a exemplo de Veloso, 1940), mas para a importância da alimentação na época moderna, como um assunto merecedor de estudo acurado por parte não só de médicos como também de biologistas, higienistas, economistas e sociólogos. Era no âmbito de uma história recente da ciência da nutrição, e nas fronteiras desses diversos campos/especialidades, que ele reconhecia o grupo fundador desse campo, bem como os seus precursores. O médico precisava, na grande maioria dos estados mórbidos do organismo, sobretudo aqueles conhecidos sob o nome de doenças da nutrição - diabetes, gota, nefrose lipóidica -, ter perfeito conhecimento de alimentação, para poder prescrever e aconselhar um regime. O biologista, estudioso dos problemas referentes à vida em todas as suas manifestações, necessitava saber como podia viver um ser animal ou vegetal - e por este motivo não podia desconhecer matéria tão importante como a alimentar. O higienista, preconizador dos meios tendentes a garantir saúde perfeita e prevenir as doenças, não devia ignorar os preceitos alimentares capazes de manter o organismo em estado de boa resistência e, quiçá, de higidez.

Para Siqueira (1940), o que não se compreendia, até há bem pouco tempo, e muita gente não queria compreender ainda, era a razão pela qual a alimentação se tornou objeto da atenção de economistas e sociólogos. Foi por essa ótica que destacou a Grande Guerra Mundial de 1914-1918 como o marco de uma época que, além de ter trazido um conto de miséria e desgraças, trouxe também, em compensação, muita coisa útil. Uma delas, desconhecida até então, foi o conceito do capital-alimento. O alimento valia seu peso em ouro, e tudo aquilo que fosse esbanjado era prejuízo monetário. Além disso, visando ao fato de o alimento levar ao capital-homem os elementos indispensáveis à manutenção da saúde, era desnecessário assinalar que uma alimentação mal dirigida, trazendo perturbações de saúde, acarretaria também prejuízos de ordem econômica.

Daí o motivo pelo qual o economista voltou também suas vistas para o campo alimentar, pois o capital-alimento, como qualquer outro capital, precisava, 
para não provocar déficit, ser bem conhecido para ser bem aplicado. Quanto a isso, Siqueira (1940:11) reiterava a afirmação de Moscoso, pela qual "o objetivo econômico da alimentação é assegurar a aptidão para o trabalho e incrementar a produção, ou em síntese, enriquecer um país". Assim, o autor reiterava que a importância da alimentação era grande, destacando o livro recente de Ruy Coutinho, por exemplo, em que havia estudado admiravelmente bem o assunto, sobretudo no aspecto relativo à nutrição e eficiência dos grupos sociais, mostrando não haver raças nem povos superiores e sim povos bem alimentados e mal-alimentados.

Nesse ponto vale destacar que havia diferentes visões entre os intelectuais quanto aos nomes dos fundadores e dos precursores. Nomes que, para Veloso (1940), estavam no grupo fundador (Afrânio Peixoto, Carlos Sá, por exemplo), para Siqueira (1940), estavam entre os precursores. Não obstante este autor assinalasse que, infelizmente neste País, datava de muito pouco tempo o interesse brasileiro pelo problema alimentar, não queria com isso dizer que ninguém dele tivesse cuidado. Não. Alguns nomes, precursores da "nossa campanha alimentar", não podiam nem deviam ficar no esquecimento, quando se processava, naquele momento, um movimento intenso em prol de uma melhor nutrição do povo daqui, começando mesmo o governo a cuidar da questão. Assim, Afrânio Peixoto, Souza Lopes, Alfredo Antonio de Andrade, Carlos Sá, Eduardo Magalhães, Souza Costa, Miguel Couto, Miguel Pereira e outros, em esforços isolados, focalizaram, muitas e muitas vezes, o assunto. No entanto:

De uma década para cá, vultos de responsabilidade no cenário médico-social brasileiro - Helion Póvoa, Austregesilo, Berardinelli, Josué de Castro, Castro Barreto, Alexandre Moscoso, Ruy Coutinho, Cleto Seabra Veloso, Moura Campos, Sinval Lins, Murilo de Souza Campos e outros mais começaram a fazer uma verdadeira revolução - a alimentar - no sentido de melhorar as condições físicas, intelectuais, morais e sociais do nosso povo que muito deixam a desejar em virtude de má alimentação. Cabem muito bem aqui as judiciosas expressões de Alexandre Moscoso: "Tudo que se fizer em favor da bôa alimentação do trabalhador nacional será pelo fortalecimento da raça e pela riqueza do País, porque trabalhador é todo o indivíduo que produz, não importa a espécie de atividade. O trabalhador nacional bem nutrido produzirá para o Brasil". (Siqueira, 1940:10-11)

É digno de nota que, diferentemente de Veloso, esse autor não vinculou o reconhecimento desse grupo ao desenvolvimento histórico da fisiologia em particular, mas no âmbito de uma história recente da ciência da nutrição e nas fronteiras dos diversos campos/especialidades: o médico, o biologista, o higienista, o da sociologia e da economia. Isso explica por que Siqueira (1940) não 
desenvolveu uma abordagem detalhada e definidora do campo disciplinar da fisiologia, embora assinalasse que os estudos modernos dessa ciência, sobretudo os dos últimos 20 anos anteriores à sua obra, tivessem estabelecido fundamentos sólidos sobre o que se devia entender por uma alimentação racional ou harmônica. Simplesmente, ele não pretendia descrever (a exemplo de Veloso, 1940), a evolução de todas as noções que tiveram por fim determinar as bases de uma boa alimentação, pois, para ele, os trabalhos de McCollum, Graham Lusk, Gautier, Funk e outros aí estavam para um estudo mais aprofundado. Siqueira (1940) advertia, então, que procuraria sintetizar, apenas, os princípios clássicos e fundamentais da ciência da nutrição, como pré-requisito necessário à análise do problema alimentar brasileiro. De fato, o autor esteve muito mais voltado para a definição dos aspectos higiênicos, dietéticos e sociais da alimentação, na perspectiva dos campos disciplinares da higiene - dietética - educação. Quanto a isso, o processo de definição dos campos disciplinares/especialidades só vai adquirindo claridade e consistência no decorrer dessa exposição.

Para isso, vale destacar que o autor, voltando-se para dentro da produção do próprio grupo fundador, transcrevia a definição de alimentação racional estabelecida por Moscoso como aquela que visava "garantir a saúde, dar energia para o trabalho, refazer os tecidos, assegurar a nutrição para a procreação sadia e forte, estimular o rendimento de produção, beneficiar o país e melhorar as condições vitais de sua população" (Siqueira, 1940:13).

Nesse enfoque, afirmava-se o princípio de que as bases de uma alimentação racional estavam sob a dependência de três fatores: o valor energético, o valor plástico e o valor regulador dos alimentos. Quanto ao valor energético, os alimentos forneciam ao organismo duas formas de energia: a mecânica e a calorífica, esta para servir ao trabalho muscular, quer externo (deslocamentos do corpo etc.) quer interno (circulação do sangue, respiração etc.). O equilibrio dinâmico da vida resultava de igualdade calorífica entre receita e despesa alimentares. Segundo os estudos da Organização de Higiene da Sociedade das Nações, as necessidades calóricas médias foram assim determinadas: adulto, vivendo em condições normais, em clima temperado e em repouso relativo -2.400 calorias por dia. Para a atividade muscular deviam ser acrescidos às 2.400 calorias os seguintes suplementos:

- trabalho muscular leve: até 75 calorias por hora de trabalho;

- trabalho muscular médio: até 75-100 calorias por hora de trabalho;

- trabalho muscular intenso: até 150-300 calorias por hora de trabalho; e

- trabalho muscular muito intenso: até 300 calorias e mais por hora de trabalho.

Para as mulheres grávidas, o número de 2.400 calorias era necessário, e para as mães que amamentavam, 3 mil calorias. 
Quanto ao valor plástico, os alimentos forneciam o material necessário ao funcionamento vital e ao trabalho de constante renovação dos tecidos. Nesse aspecto, os indivíduos jovens e as crianças tinham naturalmente gastos mais elevados que o adulto de peso e altura estáveis. Enquanto naqueles havia gastos de crescimento e de renovação, nestes só havia os de reparação. Porém, o valor regulador dos alimentos estava na contribuição dos bioquímicos do século XX, pois os do século passado julgaram ter estabelecido e surpreendido toda a mecânica da alimentação pelo conhecimento dos fatores plásticos e energéticos dos alimentos. Nessa visão de Siqueira (1940), os sais minerais, além do seu valor plástico, e as vitaminas figuravam como integrantes indispensáveis às reações vitais. Finalmente, esse autor reiterava a definição de substância alimentar estabelecida por Escudero como "toda aquela capaz de integrar-se aos tecidos ou de impedir ou retardar a modificação do seu estado físico-químico" (Siqueira, 1940:15). As substâncias que, reunidas de uma maneira harmônica, deviam entrar no regime alimentar eram: proteínas; hidratos de carbono; gorduras; sais minerais e água, além de vitaminas.

Na mesma trilha de Veloso (1940), esteve Peregrino Júnior (1941), no seu livro Alimentação: problema nacional, ao identificar, por um extenso Inventário Bibliográfico, os precursores da ciência da nutrição e reconhecer o grupo fundador. No entanto, ele não vinculava os nomes à fisiologia nem demarcava esse campo disciplinar, ilustrando, mais que explicando, que eram numerosas e antigas, na literatura brasileira, as referências ao problema da alimentação. Historiadores, sociólogos, médicos e viajantes não se cansavam de examinar e discutir tema tão importante, pois, evidentemente, era preciso encaminhar a solução do problema da alimentação, para permitir à gente da terra nova a ampliação da sua capacidade de produzir riqueza. Para ele:

Não podíamos ter a veleidade de pensar, por conseguinte, que fosse de hoje, ou de agora, que os estudiosos das coisas brasileiras viessem revelando interêsse pela questão da alimentação nacional. Todos os investigadores - e foram ilustres - e numerosos - que estudaram e debateram essa matéria, mostraram compreender com tal ou qual nitidez a sua influência primacial no desenvolvimento dos complexos fenômenos de ordem econômica e social da formação brasileira. (Peregrino Júnior, 1941:22)

Percorrendo a bibliografia do assunto, era possível dar um balanço nas informações e opiniões que, desde os dias remotos da colonização, vinham servindo de base para o estudo de tão palpitante tema. No inventário bibliográfico feito pelo autor, estavam títulos que iam desde o ano de 1835 até o ano de 1881, destacando o período posterior a essa última data, em que muitos outros autores se voltaram ao assunto, para debatê-lo em ângulo mais moderno e sob várias luzes. 
Assim, esse autor reiterava quase os mesmos nomes indicados por Veloso (1940) como fundadores desse campo, indicando que:

Nos últimos dez anos, o assunto apaixona de tal sorte os espíritos, no Brasil, que na relação extensa e ilustre dos que publicaram trabalhos sôbre alimentação, se incluem as nossas melhores inteligências, os nossos nomes mais eminentes: Anes Dias, Hélion Póvoa, Gilberto Freyre, Roquete Pinto, A. Osorio de Almeida, Renato Sousa Lopes, Sinval Lins, Paula Sousa, Araújo Lima, Alfredo de Andrade, Sebastião Barroso, Alexandre Moscoso, Henrique Roxo, Moura Campos, Castro Barreto, Paula Rodrigues, Almeida Junior, J. de Barros Barreto, Talino Botelho, Couto e Silva, Rui Coutinho, Messias do Carmo, Dante Costa, Sálvio de Mendonça, Robalinho Cavalcanti, Rubens Siqueira, Pompeu do Amaral Carlos Sá, Rubem Descarte de Paula, Celina M. Passos, Hélio Luz, Tomaz Figueiredo Mendes, Costa Couto, Ulhôa Cintra, M. Maurício Ielpo, Deodato de Morais, Josué de Castro, Cleto Seabra Veloso, Afranio Peixoto. (Peregrino Junior, 1941:27-28)

É interessante notar que os intelectuais, ao procederem ao reconhecimento dos precursores brasileiros, ao tempo em que reconheciam $e$ atribuíam um traço distintivo aos fundadores (inauguradores do novo paradigma científico), registravam filiações, descrevendo os vínculos que uniam as antigas representações e a nova matriz explicativa, sem renunciar à ênfase na distância que separava uma da outra e assinalar um corte, já que as construções discursivas precedentes estavam longe de ocupar um terreno científico, apenas o perseguindo. Como bem ressalta Delaporte:

Para fazer a dupla função de uma construção discursiva é necessário deixar de considerar que ela tem o estatuto de uma antecipação ou, ao contrário, que ela se opõe inteira, ao advento do saber. É preciso, antes, dissociar seus componentes, de modo a atribuir-lhe um papel negativo ou um papel positivo. (Delaporte, 1994:29)

Tal processo de reconhecimento recebeu ênfase, também acentuada, no campo da química, no livro de Carmo (1942), Nutrição, no qual ele reuniu uma série de conferências que proferiu, em sua maioria, em sessões de estudos da Associação Brasileira de Farmacêuticos, com a finalidade de divulgar conhecimentos que se achavam, segundo ele, esparsos, por forma muito difusa, em copiosa bibliografia, pouco acessivel..$^{21}$ Quero com isto assinalar que tal

${ }^{21}$ Nesse aspecto, a obra de Carmo é densa. Foi prefaciada por Irineu Malagueta, mestre e primeiro presidente da Sociedade Brasileira de Nutrição, que, por iniciativa da Associação Brasileira de Farmacêuticos, o referido autor ajudou a fundar na capital federal. Foi prefaciada também pelo professor Abel de Oliveira (um dos líderes da Farmácia e segundo presidente da referida Associação), ao qual devia a classe farmacêutica marcadas iniciativas, sobretudo no ensino e na legislação. 
reconhecimento, bem como a definição do campo disciplinar da fisiologia, passava, de fato, pelo enfoque da química na história.

Nessa perspectiva, Carmo (1942) apresentava a primeira conferência em que havia abordado o Panorama Atual da Nutrição, no III Congresso Brasileiro de Farmácia, em 1939, visando a uma síntese das aquisições mais recentes da ciência da nutrição, tanto quanto possível, acompanhada da contribuição, sempre valiosa, do farmacêtico nesse importante setor de atividades. Com isso, ele afirmava que, naquele momento, nenhum ramo da ciência tinha avançado mais do que o da nutrição, que vinha merecendo os desvelos de sociólogos, médicos, químicos, professores etc. Acompanharam este movimento de atividades, em pleno sucesso imposto pelo novo padrão de estudos, as universidades e os grandes centros de pesquisa de todo o mundo.

Ao assinalar as conquistas da nova ciência em foco, e de suas conseqüências sociais, Carmo enfatizou que a orientação prática impressa aos estudos da nutrição, naqueles últimos anos, se encadearam na mesma direção em que os sociólogos conduziram as suas observações, isto é, para o terreno da previdência com acesso imediato à assistência social. Exemplo disso foi o pioneirismo de Pedro Escudero, na Argentina, que firmou a ciência da nutrição, tanto na esfera social, como em aplicações práticas e, nesse sentido, a fundação do Instituto de Nutrição de Buenos Aires era uma obra de valor continental. Foi também um marco histórico o suporte técnico-científico desenvolvido pela Sociedade das Nações, por meio da sua Seção de Higiene, para onde convergiam técnicos de todo o mundo para prestar sua colaboração, o que significava dizer, na visão de Carmo (1942:31), que essa instituição vinha trabalhando útil e proficuamente para a paz do futuro, "a paz pela ciência".

Depois da Primeira Grande Guerra, as pesquisas da química da nutrição, estimuladas pela necessidade urgente do ambiente social, enveredaram pelo caminho prático das avaliações do valor nutritivo dos alimentos, para imediata aplicação à economia humana. Era por esse ângulo que a constituição do campo da nutrição/educação alimentar estava vinculada aos farmacêuticos. É digno de nota que, no conjunto das obras em foco, os autores utilizaram e anexaram, além da tabela de composição química dos alimentos elaborada por Alfredo de Andrade, em 1923, a de Oswaldo de Almeida Costa divulgada em 1936 e a de Vasco Azambuja em 1938.

No entanto, Carmo (1942) assinalava que, pela primeira vez na história das ciências, uma convergência de determinismo era forçada pela realidade, na fatalidade brutal das conseqüências do pós-guerra. Os sociólogos se alarmavam com as carências de alimentação, cronificadas pelo longo pesadelo dos quatro 
anos de guerra e de subalimentação. Era a época da ração reduzida e da estocagem. Surgiam, então, em plena civilização, os quadros clínicos antigos, as moléstias de carência que grassavam nos tempos das cruzadas e dos longos cruzeiros marítimos. "A história recapitulava a história!":

A Geografia criara a História Natural, a Biologia, pela nutrição, propõe-se a reformar a geografia! Depois de um longo período da história do homem, a Biologia aproxima-se de todas as ciências, em busca do seu lugar geométrico. (Carmo, 1942:7)

Nesse aspecto, embora Carmo reservasse um lugar para o Brasil, assinalava muito mais o pioneirismo externo na configuração do campo em foco, enfatizando que a cooperação do farmacêutico tinha sido muito eficiente em todo o mundo, sobretudo no estudo acurado das vitaminas, para aplicação terapêutica. Assim é que, em 1933, a seção de Farmácia e Química e de Alimentação da Associação Médica Americana promoveu uma série de trabalhos profundos sobre vitaminas, confiando quase inteiramente a farmacêuticos a revisão de toda a matéria. $O$ The Journal vinha publicando sucessivamente as monografias de atualização. A título de exemplificação, Carmo cita alguns trabalhos e nomes de farmacêuticos americanos cuja impressionante obra muito dignificava a cultura farmacêutica. Entre outros, o farmacêutico George R. Cowgill, do Laboratório de Química Fisiológica da Universidade de Yale, que escreveu sobre a fisiologia da vitamina $\mathrm{B}_{1}$; Lela $\mathrm{E}$. Booher, que estudou, em artigo especial, as necessidades em vitaminas para todas as idades; $H$. A. Matill, que aperfeiçoava os estudos da vitamina $E$, no que se referia à sua função na reprodução; I. S. Palmer, que estudava a química da vitamina A; Henry C. Sherman e Caroline Sherman Lamford, que estudavam a riboflavina, dando o valor desse elemento numa extensa lista de alimentos. Em 1937, três substâncias foram isoladas desse complexo. A primeira, riboflavina, de que se ocuparam os autores citados; a segunda, a vitamina $B_{6}$, e a terceira, o complexo P-P de Goldberger, substância preventiva da pelagra humana. Nesse percurso, Carmo exaltava o desempenho da Sociedade das Nações no estabelecimento de regras de padronização das substâncias medicamentosas para assegurar o seu poder terapêutico, bem como da constante nutritiva dos gêneros alimentícios, tendo realizado conferências várias em Edimbourg (1923), Genebra (1925), Frankfurt (1928), e nas suas últimas reuniões, 1931, 1935 e 1938, ocupando-se em pôr ordem nos estudos sobre vitamina.

Desse modo, a ciência da nutrição havia recebido, para o seu progresso, o contingente de colaboração das mais variadas categorias profissionais. Foi essa orientação, aliás, que apressou a sua maioridade. Quanto a isso, a fisiologia, como campo disciplinar concebida por Carmo (1942) nos domínios da química, 
recebia a colaboração dos farmacêuticos. Era de justiça, então, reivindicar para - Brasil uma posição de destaque entre os países pioneiros nos estudos da nutrição, mediante estudo do oftalmologista Gama Lobo que, em primeiro lugar, observou os sintomas característicos da síndrome de avitaminose A, em 1864, denominada de 'oftalmia brasiliana'. As suas observações foram feitas em crianças escravas, de dois a sete anos e apresentadas à Real Academia de Medicina, que as publicou nos Anais Brasiliensis de Medicina, em 1864.

De fato, Carmo (1942), em consonância com Veloso (1940), anunciava que a fisiologia da nutrição deveria ser encarada à luz da bioquímica e da fisiologia. A primeira, com um sentido puramente molecular e atômico, estudava as transformações dos elementos, emprestando ao trabalho biológico as suas propriedades físicas e químicas. A segunda estudava o organismo no conjunto dos seus órgãos e no consenso de suas funções. Desse ponto de vista, a fisiologia da nutrição podia ser apreciada em três aspectos diferentes:

- conversão dos alimentos em compostos essenciais à vida, capazes de fornecer matéria e energia;

- crescimento; $e$

- reprodução (nutrição da espécie).

Nessa perspectiva, a nutrição era concebida como um fenômeno universal que condicionava a vida sobre o planeta.

O autor entendia por metabolismo o conjunto de transformações bioquímicas que se passavam incessantemente no organismo, para manutenção da vida. Começava o metabolismo onde terminava a digestão. Toda química da digestão se realizava fora dos tecidos, ao passo que a ação metabólica tinha lugar depois da absorção, no seio das células, quando, veiculados pelo sangue, os produtos finais da digestão se encontravam com os produtos finais da respiração. O metabolismo se desenvolvia nitidamente em duas fases: uma construtiva, compreendendo processos de reparação e de crescimento - era o anabolismo. A outra, destrutiva, agia por decomposição do edifício molecular, dando lugar sempre à liberação de energia para o trabalho muscular e a regulação térmica - era o catabolismo. Em condições fisiológicas, havia sempre o equilibrio das duas fases, não obstante ser o período inicial da vida caracteristicamente anabólico, sendo o declínio uma fase de catabolismo biológico. Era em face da lei da conservação da energia que o organismo humano podia ser comparado a uma máquina, com muitos pontos comuns de contato:

- a energia de trabalho era obtida pela oxidação ou queima do alimento, como se fora um combustível; 
- os fenômenos se passavam de conformidade com a lei de conservação de energia, semelhantemente, no que dizia respeito à produção de trabalho $e$ calor; $e$

- em ambos se desenvolvia a fórmula geral de transformação de energia em trabalho: energia do alimento ou do combustível + energia do oxigênio $=$ energia dos gazes formados + calor + energia.

No entanto, para Carmo (1942) era necessário distinguir: o rendimento da máquina humana não era igual ao da máquina mecânica, pois a primeira dependia do seu grau de higidez, de fadiga, de treino e até mesmo de predisposição. Era um mecanismo nobre e caro para manutenção, sobretudo em climas extremos, em razão do seu delicado aparelho termo-regulador:

O estudo da máquina humana muito tempo feito analógicamente com a máquina mecânica, deteve os pesquisadores dentro de uma fórmula interpretativa demasiado simples em relação à alimentação - 'Dieta balanceada e calorias suficientes'... (Carmo, 1942:39)

$\mathrm{Na}$ visão desse autor, as coisas não se passavam tão simplesmente: o ser humano dependia de múltiplos estímulos, muitos dos quais se subordinavam ao psiquismo, dependentes da emoção. Para bem esclarecer o problema, o método se dicotomizava: estudava-se o alimento ingerido e a sua utilização pelo organismo.

Foi por esse ângulo que o autor em apreço definia, a exemplo de Veloso (1940), os vários estágios fisiológicos da nutrição enfocados em várias conferências, os quais, em última instância, constituíam pontos de estudo desse campo disciplinar: mecanismo da respiração, mecanismo da digestão, metabolismo dos protídios e seu valor biológico e coeficiente de utilização, metabolismo dos glicídios, metabolismo dos lipídios, metabolismo mineral e introdução ao estudo das vitaminas.

Nesse aspecto, Carmo (1942) avançava em relação aos demais autores citados, ao afirmar que, se a história atestava que nos cursos de farmácia o estudo da química bromatológica foi sempre um estímulo para o farmacêutico se interessar pelas questões de nutrição, nos cursos médicos, só muito raramente, isso mesmo por interpretação pessoal dos professores de terapêutica ou de clínica, eram ministradas noções de nutrição aplicadas à dietética, como acontecia nas cátedras dos professores Annes Dias, Renato Souza Lopes, Clementino Fraga, Irineu Malagueta e poucos outros. ${ }^{22}$ Sob esse ângulo, era inconteste a necessidade

${ }^{22}$ A este respeito, NATAL (1982:36), em seu estudo, assinalou a criação, em 1933, da primeira cadeira especializada em nutrição na Universidade do Distrito Federal, sob a responsabilidade de Annes Dias, para estudar os aspectos médico-higiênicos do problema. 
de ser instituído o ensino da nutrição nos cursos médicos e de farmácia, aproveitando Carmo a reunião do congresso para propor às autoridades o que ele considerou um esboço das linhas gerais do curso:

- química e fisiologia aplicadas à nutrição;

- noções sobre os alimentos e o seu valor nutritivo. Vitaminas;

- necessidades energéticas do organismo. Subalimentação. Desvios da nutrição;

- dieta normal, classificação; dieta do doente. Equilißrio ácido-básico. Alterações terapêuticas. Dietas restritivas;

- ordenação de dietas. Cardápios. Cozinha dietética;

- produção e transporte. Preço da vida. Economia doméstica;

- usos e costumes. A psicologia da mesa. A alimentação em função das raças e do meio; $e$

- assistência social e alimentação.

Embora o esse autor não tenha definido claramente as especialidades/ profissões, fornecia elementos indicativos para se pensar que era na interface do campo disciplinar da fisiologia que se justificava a incorporação do conhecimento da nutrição na formação do médico, fato que se concretizou em 1944, no interior do Serviço de Alimentação da Previdência Social. Como será visto, o médico recebia um novo distintivo - o nome de nutrólogo.

Conforme o documento da Associação Brasileira de Nutrição, nesse processo organizativo, Dante Costa foi convidado por Hélion Póvoa, primeiro diretor do SAPS, para organizar a Seção Técnica dessa instituição, que foi oficialmente criada em 1943, quando se deu a modificação da sua estrutura. Assim, a Seção foi concebida à luz de quatro objetivos:

- realizar trabalhos de planejamento dietético;

- realizar atividades de educação alimentar;

- realizar serviços de inspeção da alimentação de coletividades;

- realizar pesquisas biológicas e químicas no campo da nutrição experimental.

Para o cumprimento de tais objetivos, essa Seção foi dividida em três turmas: turma de alimentação; turma de educação; e turma de pesquisa. Para o propósito desse estudo, destacam-se apenas as principais características da turma de educação, embora se trate do primeiro momento da institucionalização da educação alimentar, e remete-se o leitor ao documento em foco, para maior conhecimento das demais turmas. A turma de educação tinha "como finalidade promover, nos lares dos trabalhadores, e em quaisquer outras oportunidades, em todos os locais em que isso seja possivel, a mais extensa e adequada educação alimentar. Esta é uma das mais importantes turmas da Seção. Cumpre a ela, 
em última análise, contribuir para a remoção dos maus hábitos alimentares do brasileiro - e só o enunciado desse objetivo dá idéia do seu significado humano e social" (Associação Brasileira de Nutrição, 1991:51).

Como consta do citado documento da Associação Brasileira de Nutrição (1991:29), o Decreto-Lei no 5.443, de 30 de abril de 1943, modificava a estrutura administrativa do Serviço de Alimentação da Previdência Social (SAPS), criando os restaurantes populares e autorizando a criação de cursos técnicos $e$ profissionais, como rezava o seu artigo 2․:

Fica o Diretor do Serviço de Alimentação da Previdência Social - Saps, autorizado a criar cursos Técnicos e Profissionais para formação de pessoal técnico necessário as atividades de nutrição e bem assim de bons profissionais de copa, cozinha e atividades afins ligadas à alimentação.

Isso permitiu que fosse criado, em 1944, o curso de nutrólogos com duração de dois anos, incorporando as seguintes cadeiras: $1^{\circ}$ ano-fisiologia da nutrição, dietética, tecnologia alimentar, bromatologia; $2 \circ$ ano - patologia da nutrição, dietoterapia, técnica dietética e estudo sócio e econômico da alimentação. Tal fato pode ajudar a esclarecer mais adiante nesta exposição a tão polêmica questão que se coloca atualmente sobre a identidade da profissão do nutricionista, no âmbito de uma formação subordinada ao campo médico.

É digno de nota que a incorporação do ensino da nutrição no curso médico se dava num momento em que a medicina já se constituía prática hegemônica, sobretudo nos grandes centros urbanos e concomitante ao processo de industrialização do País, coibindo todo e qualquer exercício médico que estivesse fora de jurisdição científica. Entre os anos 20 e 40, por exemplo, São Paulo já contava com 56 associações médicas e paramédicas, número que, comparado às cifras anteriores, indicava um elevado grau de organização e da prática médica nesse período. No entanto, o fator decisivo para o alcance da maioridade da medicina como prática hegemônica foi o desenvolvimento de um arsenal técnico e eficaz (especialmente as vacinas) de combate às pestes, à lepra, ao tifo, à varíola, à febre amarela, assegurando o controle sanitário e detecção de focos contagiosos. Nesse aspecto, é importante assinalar que a inclusão na pauta dos processos reivindicatórios das massas trabalhadoras urbanas, de oferta de cuidados gratuitos de saúde e assistência médica por parte do Estado atesta, em certa medida, a dimensão da legitimidade que a medicina passou a ter para as camadas sociais que até então transitavam pelas práticas das terapias chamadas tradicionais (Monteiro, 1985). 
O processo de urbanização que, a partir dos anos 30, deslocava definitivamente o eixo produtivo e político do País do campo para a cidade destruía a rede de relações sociais que permitia, no meio rural, a conservação e transmissão de saberes relativos ao reconhecimento das doenças e ao repertório dos remédios. Em sua migração para as cidades, tais saberes se perderam. As descrições populares da doença no meio rural apresentavam grande similaridade com as formulações hipocráticas, aperfeiçoadas por Galeno, segundo as quais a saúde era concebida como relação de equilíbrio entre os quatro humores: o sangue (quente e úmido), a flema (fria e úmida), a bile negra (fria e seca) e a bile amarela (quente e seca) (Monteiro, 1985). Nessa visão, uma dieta equilibrada constituía-se, pois, em peça fundamental da manutenção da saúde, como bem assinalam Campos (1982) e Brandão (1981). Além disso, ao lado das descobertas técnico-científicas que asseguravam à medicina o controle das doenças infecciosas, as novas condições de vida na periferia das cidades, a miséria, o trabalho fabril transformavam o quadro nosológico anterior (febre amarela, varíola, lepra etc.) nas chamadas 'doenças de massa' (verminose, esquistossomose, tuberculose, desnutrição etc.), ao tempo em que ganhavam expressão as doenças crônicodegenerativas resultantes das condições de tensão a que era submetido o indivíduo no cotidiano da vida urbana. Com isso, o repertório mais ou menos estático da medicina popular tradicional já não se ajustava às necessidades desse novo quadro nosológico, tornando-se estreito e inadequado, ganhando cada vez mais espaço a medicina universitária, e sua atuação cada vez mais eficaz sobre as doenças que até então dominavam o quadro mórbido da sociedade brasileira.

É por essa ótica que se deve entender a incorporação do ensino da nutrição na formação do médico, à luz do processo definidor dos distintos campos disciplinares da ciência da nutrição, particularmente da educação alimentar, como veículo pedagógico de difusão das regras e preceitos científicos para a população. Era por referência à instauração de uma nova racionalidade no cenário cultural que o conceito de ração alimentar racional foi construído, delimitando novos parâmetros de normatividade necessários à intervenção no modo brasileiro de se alimentar.

Em verdade, a preocupação com a incorporação do conhecimento da nutrição na formação do médico não parou com a criação do curso de nutrólogos, em 1944. A título de ilustração, um estudo de Bezerra (1980), nas 74 escolas de medicina em funcionamento no País, constatou que apenas 21 desenvolviam o ensino da nutrição, no qual constava, entre outras matérias de ensino, a educação nutricional (na terminologia atual), o que significa dizer que a educação alimentar se institucionalizou, também no curso médico, em tempo posterior à criação do 
curso de nutrólogos. Após 11 anos de levantamento, o autor atestava uma sensível melhora no nível de ensino, pois foram criadas disciplinas de nutrição em mais 18 escolas de medicina. Isso sugere que o campo da formação médica continua fortalecendo o ensino da nutrição no seu âmbito, fator importante na formação e na expansão do médico nutrólogo.

Portanto, a definição do campo disciplinar da fisiologia estava nas fronteiras com a história cujo corte foi operado por um grupo intelectual que afirmava a sua identidade coletiva na produção de um novo paradigma instaurador da ciência da nutrição/educação alimentar, tendo a fisiologia como ponto de partida para a sua configuração. Quanto a isso, pode-se antecipar que, sendo a fisiologia da nutrição o campo definidor da identidade desta nova especialidade profissional enquanto traço que a distinguia de outras especialidades externas - químicos, físicos, fisiólogos, bacteriólogos -, ficava o dietólogo-nutrólogo imbuído não somente da competência e da legitimidade para o exercício da prescrição dietética e do tratamento das patologias a ela subjacentes (dietoterapia), como também do domínio sobre a produção teórico-instrumental do campo científico da nutrição, distinguindo-se internamente do dietista. Nisso reside a explicação para a antiga questão sobre a identidade da profissão do nutricionista e sua formação, como será visto a seguir.

\section{Higiene alimentar e educação alimentar: o princípio de tudo}

Na visão de Veloso (1940), a higiene alimentar era a razão de ser da ciência da nutrição, o objetivo da dietética, e a educação alimentar estava a ela vinculada. Quanto a isso, ele transcrevia a definição de Afrânio Peixoto segundo a qual higiene "é um conjunto de preceitos, buscados em todos os conhecimentos humanos, mesmo fóra e além da medicina, tendentes a cuidar da saúde e poupar a vida" (Veloso, 1940:199).

Nessa visão, o campo da higiene alimentar compreendia uma lista de dez pontos de estudo que seguiam a mesma ordem numérica adotada no campo disciplinar da fisiologia:

$20^{0}$ - Higiene da alimentação. Hábitos alimentares do homem em geral. Hábitos alimentares do brasileiro. O homem é onivoro.

$21^{2}$ - Alimentos minerais, (Alimentos simples) Água, oxigênio e sais minerais.

$22^{2}$ - Alimentos compostos de origem animal. (Substâncias alimentares) Carne, leite, ovos.

$23^{2}$ - Alimentos compostos de origem vegetal. (Substâncias alimentares) Cereais, leguminosas, verduras e frutas. Os condimentos. 
$24^{\circ}$ - Como se alimentava o povo brasileiro. Alimentação das classes abastadas e da mediania. Alimentação da criança. Alimentação das classes pobres. Inquéritos realizados no Brasil.

$25^{\circ}$ - Conseqüências biológicas e sociais decorrentes da má alimentação. Racionalização alimentar.

$26^{\circ}$ - Alimentação e duração da vida. Quantos anos deveria viver o homem. Alimentação, clima e herança.

270 - Alimentação e mortalidade infantil no Brasil. Causas responsáveis - as infecções, a alimentação, o perigo congênito. Das organizações de assistência.

$28^{\circ}$ - O ensino da alimentação no Brasil. Na escola primária. Nas escolas secundária e superior. Educação alimentar para o povo.

$29^{\circ}$ - Regras para conservação da boa saúde. O peso. A atitude. O exame periódico de saúde. (Veloso, 1940:segunda parte)

Significa dizer que, nessa definição de Veloso (1940), a educação alimentar - no âmbito da higiene alimentar - não se configurava como campo disciplinar específico e autônomo, mas como tema integrante do corpo temático da higiene alimentar (a qual era uma antecedente, se assim se pode dizer, da disciplina nutrição em saúde pública atual). Quanto a isso, o autor começava sua exposição com uma transcrição de Turner, extraída do Jornal da Associação Americana de Dietética: "Não há campo do conhecimento em que a educação sanitária do povo seja mais importante do que o da nutrição" (Veloso, 1940:321).

Para ele, o ensino da alimentação tinha que começar pela escola primária. Era aí que a criança deveria receber dos seus professores as primeiras noções elementares sobre alimentação. Aprender que a carne, o leite, os ovos, as frutas e as verduras eram alimentos necessários ao seu desenvolvimento e à sua formação, sem o que jamais chegariam a ser homens fortes; aprender que os bombons de chocolate, as balas, os pastéis e outras tantas guloseimas lhes eram prejudiciais, tirando o apetite para as principais refeições do dia e causando distúrbios digestivos que, aparentemente insignificantes, não deixavam, no entanto, de repercutir desastrosamente na economia; aprender, enfim, a utilizar os alimentos, preferindo os mais ricos em princípios nutritivos aos mais pobres, a exemplo do leite. Com 200 réis apenas podia uma criança tomar um copo de leite, em lugar de gastar essa importância com doces ou balas, que pouco lhe adiantavam (Veloso, 1940).

As noções sobre granja, como fator de produção de alimentos; a importância da agricultura, da pecuária, das hortas, dos pomares etc., devia a criança aprender, igualmente ,na escola primária. Segundo Veloso (1940), na América do Norte, como dizia Escudero, a National Live Stock and Meat Board, dedicada ao comércio de carnes, publicou, em 1926, uma cartilha para as 
escolas, denominada Dez Lições sobre Carne, reeditada em 1927 e em 1933, pondo ao alcance dos mestres e discípulos todos os conhecimentos fundamentais sobre esse alimento primordial.

Nessa visão, era a escola primária incumbida do dever de transmitir ao espírito da criança que se educava as noções fundamentais sobre a importância da alimentação na vida humana. Com esses primeiros ensinamentos, o terreno estaria aplainado e semeado. Quando a isso, Escudero era mais uma vez revelado em transcrição de Veloso (1940:322):

O abandono, o esquecimento total do ensino da alimentação na 'escola primária' é a causa mais importante dos males que afligem a população infantil eoperária, no que respeita a saúde. Não é o médico quem deva prevenir umas tantas moléstias: quando êle é chamado, a 'doença' já se encontra em adiantado estado e a terapeutica não pode oferecer garantia eficiente. $O$ bom exito se consegue quando o mal é descoberto nos primeiros anos. E isso só é possível na escola primária, onde a professora está em contacto direto e prolongado com a criança anos a fio.

No entanto, o ensino secundário e universitário no Brasil, até aquela época, não havia se preocupado com o estudo da higiene alimentar. Saía a nossa juventude das escolas secundárias e superiores - ginásios, liceus, academias, universidades -, ignorando tudo a respeito de alimentação e nutrição. Era nesse âmbito que a obra educativa teria que prosseguir até que se conseguisse formar uma grande elite em torno de tão magno problema. Nesse aspecto:

Já $P$. Escudero, tratando do assunto no seu país, reclamava insistentemente a necessidade da criação de uma 'cadeira de alimentação' na Universidade, onde os estudantes pudessem receber ensinamentos coordenados e sistematisados, dentro de uma orientação moderna, sôbre higiêne alimentar. [Sabemos hoje que a 'cadeira de alimentação' já foi criada na Universidade de Buenos Aires]. Do mesmo modo, precisamos criar 'cursos para formação de dietistas', nas nossas Faculdades, na Saúde Pública, nos serviços de alimentação - onde se diplomem centenas de moças e moços incumbidos, dessa missão nova e muito nobre, que é a profissão de dietista. É o que se faz hoje na América do Norte, na Argentina e em tantos outros países, onde se pretende melhorar as condiçōes da alimentação do povo. A Associação Americana de Dietética, já em 1934 possuía nada menos de 2.700 dietistas diplomadas, exercendo a sua profissão no seio daquêle país. (Veloso, 1940:323)

Nesse aspecto, vale destacar que tal reivindicação indicava que a ciência da nutrição e, no seu âmbito, a educação alimentar, ainda não dispunham de espaço específico no interior do qual esse saber pudesse adquirir autonomia, fato que fica claro com a modificação da estrutura do Serviço de Alimentação da Previdência Social, em 1943, como já mencionado anteriormente. Ao criar 
os restaurantes populares nos moldes cientificamente preconizados, esse serviço ficava autorizado a criar também os cursos técnicos, organizando, para isso, estruturas internas específicas destinadas à pesquisa e à educação alimentar, antes mesmo que fosse fundado o Instituto de Nutrição nos moldes universitários. No entanto, o sistema universitário em gestação no Distrito Federal já previa, desde 1937, a organização dos diversos campos do conhecimento, entre outros os da saúde, incluindo um Instituto de Nutrição. O plano de organização da Universidade do Brasil, criado pela Lei no 452, de 5 de julho de 1937, previa, no seu artigo 4, que, inicialmente, esta Universidade seria "constituída dos seguintes estabelecimentos de ensino: (...)" f) Faculdade Nacional de Medicina; g) Faculdade Nacional de Odontologia; h) Faculdade Nacional de Farmácia; (...). No artigo 5o, a referida lei previa que:

Para cooperar nos trabalhos dos estabelecimentos de ensino mencionados no artigo anterior, farão parte integrante da Universidade do Brasil os seguintes institutos: a) Museu Nacional; b) Instituto de Fisica; c) Instituto de Eletrotécnica; d) Instituto de Hidro-aero-dinâmica; e) Instituto de Mecânica Industrial; f) Instituto de Ensaio de Materiais; g) Instituto de Química e Eletro-Química; h) Instituto de Metalurgia; i) Instituto de Nutrição (...). (Brasil. Coleção de Leis e Decretos, 1938)

Assim, havia coerência na argumentação de Veloso (1940) quando afirmava que, pela falta de um ensino regular de higiene alimentar no Brasil, respondia aquela situação vexatória e deprimente para o nosso país, que se apresentava, no passado e no presente, em péssimas condições em matéria de saúde pública: com desnutrição acentuada de suas crianças e da maior parte da sua população operária, donde resultava a sua elevada mortalidade infantil e a sua média de vida verdadeiramente insignificante - 25 anos; seu alto índice de tuberculose, de anemias alimentares, de verminoses, de doenças infecciosas e tantas outras injúrias imediatamente na dependência do nosso caos alimentar.

Para o autor, a educação alimentar devia ser estendida ao povo, pois os ensinamentos educativos que devia receber o povo daqui, em matéria de alimentação - nas escolas, nos livros, na imprensa, no rádio, no cinema, em cartazes e folhetos, em conferências etc., e que lhe permitiriam familiarizar-se com as regras e preceitos da arte de bem se alimentar-, representavam uma das linhas mestras para a solução do problema alimentar no Brasil:

Visando tão alto objetivo é que escrevemos a $1^{2}$ edição de 'Alimentação'. Nela, levando muito a sério a parte científica que se nos afigura indispensável à sua melhor compreensão e finalidade, reunimos noçōes elementares mas capitais sôbre o melhor modo do indivíduo se alimentar, tendo sempre em vista o problema no nosso País. (Veloso, 1940:324) 
É digno de nota que se, no período de 1934 a 1939, os intelectuais estiveram voltados para a configuração das bases fisiológicas pelas quais definiram os parâmetros científicos da dietética, no período de 1940 a 1946, em foco, traduziam tais parâmetros em regras, ora no âmbito da higiene alimentar, ora no âmbito da própria dietética, definindo como veículo de difusão a educação alimentar. Desse modo, Veloso (1940) sintetizava a higiene alimentar detalhando regras e conselhos para a conservação da boa saúde, dirigidos ao brasileiro de forma generalizada, abrangendo quatro itens básicos:

- "Qual deve ser o meu peso?";

- "A posição do nosso corpo";

- "Exames periódicos de saúde"; e,

- "Os mandamentos da saúde".

Nessas regras, o peso era um parâmetro relacionado com a duração da vida, devendo ser incorporado pela população o ideal do biotipo médio brasileiro. Cada indivíduo tinha uma média de peso que estava em constante relação com a sua altura e a sua idade. Dentro dessa média, que era o peso fisiológico, podia haver variações para mais e para menos, de 3 a 5 quilos, por exemplo, sem que houvesse prejuízos maiores para o organismo. A vida corria sérios riscos quando esse peso excedia de 10, 15, 20 e mais da média: grande número de mortes súbitas, por colapso cardíaco, angina do peito, hemorragia cerebral, edema do pulmão etc., era observado sobretudo em pessoas obesas. As alterações do peso para menos e o emagrecimento muito acentuado submetiam o indivíduo a toda sorte de moléstias por diminuição das suas defesas. Assim, para alcançar o peso médio ótimo, Veloso (1940) indicava uma tabela padrão e a procura do médico para a obtenção de conselhos e da terapêutica indicada. Por essa tabela, um homem de $1,70 \mathrm{~cm}$, entre os 50-54 anos, devia pesar 72 quilos; uma mulher de $1,60 \mathrm{~cm}$, entre 30-34 anos, devia pesar 60 quilos.

Para esse autor, a posição do corpo, também chamada postura, ao caminhar, ao estar sentado, ao trabalhar ou ao dormir, refletia a todo instante o estado de saúde física e psíquica do indivíduo. Em suas palavras, não eram somente as pessoas doentes que se apresentavam, em geral, recurvadas, com os ombros caídos, o peito para dentro, o abdômen 'pulado' para fora. Havia muita gente jovem, em plena saúde, que, por desleixo ou coisa semelhante, adotava sempre uma postura 'feia e deselegante', quer quando sentados, quer andando na rua. Na boa postura, que era justamente aquela em que o corpo se apresentava reto, cabeça erguida, ombros para trás, abdômen reto e os pés quase se aproximando das paralelas, o organismo funcionava às 'mil maravilhas'. Os 
pulmões recebiam quantidade suficiente de ar, o coração pulsava normalmente, o estômago e os intestinos estavam livres: a circulação do sangue se fazia também em condições normais. Todas essas funções estavam comprometidas na má postura. Para corrigir tal defeito:

$\mathrm{Na}$ grande maioria, no entanto, a própria auto-educação, com exercícios diários sob uma superfície dura, o soalho, por exemplo, dão os resultados desejados. Tudo se resume em querer, em adotar um regime de vida de todo incompatível com a má postura, tendo sempre em mente que o 'equilíbrio', a 'simetria' e a 'beleza do corpo' garantem uma vida longa e cheia de saúde. É o que as mães devem ensinar aos seus filhos, desde muito cêdo; os professôres aos seus alunos; e os homens em geral adotarem entre si! (Veloso, 1940:331)

O exame de saúde devia ser difundido como uma das maiores conquistas do século XX. A medicina preventiva já dispunha de recursos para diagnosticar precocemente sintomas que, muitas vezes, passavam despercebidos à pessoa, a ponto de protelar o recurso médico até o momento em que se convencia da gravidade da doença, a exemplo da tuberculose em fase adiantada, as grandes lesões cardíacas, as úlceras antigas etc., em que o organismo não tinha mais capacidade de reagir, em face dos remédios, e sucumbia. Com isso indicava que tal exame de saúde deveria ser feito, para pessoas de boa saúde, de seis em seis meses; para as de má saúde, de dois em dois meses, ou ainda menos: era uma pequena despesa que se fazia, eram alguns mil-réis que se gastavam mas que rendiam um grande juro.

Enfim, os dez mandamentos da saúde sintetizavam tudo:

1- - Brasileiro, não descuida da tua saúde: és gordo demais, come pouco; se és magro, procura te alimentar sempre bem, com alimentos ricos em substâncias nutritivas, assim como o leite, os ovos, a manteiga fresca, a bôa carne e também os legumes e as frutas.

$2^{2}$ - Foge dos alcoólicos - vinho, cerveja, aguardente, licores, etc.; evita as comidas muito gordas, pois que a gordura produz muito calor, o que já tens em excesso no nosso clima; toma bebidas refrigerantes, água mineral, água natural, etc.

$3^{2}$ - Entre nós há sempre 'tifo', 'paratifo', 'varíola'. Vacina-te, pois, contra estas moléstias e, ao mesmo tempo, procura evitá-las tomando sempre leite cozido, comendo legumes cozidos e não bebendo águas suspeitas - de póços, cisternas rios ou riachos onde se lavam roupas, lagâ, etc.; evitando a salada de frutas e os sorvetes, quando não higiênicamente preparados.

$4^{\circ}$ - Pratica exercícios físicos todas as manhãs ao levantar - ginástica tipo Muler e outras.

$5^{\circ}$ - Procura de três em três meses um médico de confiança para o teu exame 'periódico de saúde'. E tem sempre em mente que êste constitue a segurança da tua vitalidade. 
$6^{0}$ - No teu 'regime alimentar' está o segredo da tua longa visa: sê, pois, sóbrio na tua alimentação, que deve ser a horas certas, pelo menos 4 vezes ao dia.

7- Aos domingos afasta-te de qualquer trabalho ou preocupação de espírito; entrega-te a passeios no campo, vai ao teu cinema, ouve a tua música, lê bons livros.

8- O 'banho diário' é indispensável para a higiene do teu corpo; frio no verão e morno no inverno.

9- Evita as 'moléstias contagiosas', principalmente a tuberculose, defendendote contra os seus portadores. E tem sempre em mente que o copo, a colher, a chícara, a bomba de chimarrão, o bafo das pessoas (perdigotos) transmitem esta terrível moléstia.

$10^{\circ}$ - O 'sol' é fonte preciosa de vida: toma o teu banho de sol tôdos os dias.

$11^{\circ}$ - Dorme de janelas abertas, respirando o bom ar a plenos pulmões. Evita, no verão as 'roupas de lã, as camisas de meia, as sweaters', que impedem a respiração da tua pele, aumentando-te o calor. (Veloso, 1940:333-334)

De fato, o fim último da higiene alimentar era a sistematização de um conjunto de preceitos a serem incorporados individual e coletivamente. Quanto a isso havia concordância entre os intelectuais em apreço de que a higiene alimentar era o campo de aplicação da fisiologia e razão de ser da ciência da nutrição, na medida em que procurava criar as condições mais adequadas à promoção da saúde, nos distintos gêneros de vida regionais brasileiros. Tal perspectiva implicava, também, certa concordância quanto aos pontos temáticos desse campo disciplinar. Com isso, pude perceber que se iam delineando, em meio às pequenas diferenças de abordagem, os pontos de encontro entre os intelectuais quanto à definição da base cognitiva dos diversos campos disciplinares da ciência da nutrição, incluindo a educação alimentar. Todos os fundadores alegavam que o verdadeiro objeto da nutrição era a ração/dieta configurada na relação: homem, alimento e meio sociocultural e natural, no qual uma tendência majoritária submetia a interpretação dessa tríade aos ditames do método geográfico.

Siqueira (1940), embora não tenha definido, a rigor, um campo disciplinar denominado de higiene alimentar, como fez Veloso, trazia uma estrutura temática inerente a esse campo, até porque tinha por base a orientação dada a um curso de aperfeiçoamento. Quanto a isso, os pontos temáticos não foram apresentados em ordem numérica, embora se possa perceber uma ordem entre eles: como é feita a alimentação do brasileiro nas diversas regiões, causas da má alimentação, assinalando os hábitos defeituosos afirmados desde o tempo colonial, a miséria e a ignorância; falhas alimentares das coletividades daqui; como deve ser feita a alimentação do brasileiro: divisão do Brasil em zonas alimentares - tipos padrões de dietas; os alimentos básicos característicos daqui, aproveitamento das 
substâncias regionais, e substitutivos equivalentes. Essa visão se aproximava do enfoque de Veloso, ao afirmar também que a higiene alimentar precedia a dietética, mas, ao mesmo tempo, diferia, com relação à educação alimentar, na medida em que este campo disciplinar não foi concebido no plano da higiene alimentar e sim como um campo autônomo, como será visto adiante.

Diferentemente de Veloso e Siqueira, Peregrino Junior (1941) foi buscar os antecedentes históricos da higiene alimentar na primeira cartilha de alimentação publicada em língua portuguesa, em 1749, a Ancora Medicinal para Conservar a Vida com Saúde, escrita pelo dr. Francisco da Fonseca Henriques, médico do Rei de Portugal, Dom João V. Natural de Mirandela, Fonseca Henriques era conhecido, em sua terra, como 'Mirandela'. Segundo esse autor, o dr. 'Mirandela' estudou o problema sob múltiplos aspectos: o ambiente em comum, os alimentos em particular, o sono, a vigilia, o movimento, o descanso etc. e ensinou aos seus contemporâneos muitas coisas úteis. A sua pregação constante era em defesa da sobriedade, da moderação, do equilíbrio. Nesse enfoque, o dr. 'Mirandela' não omitiu qualquer aspecto da questão alimentar: viu-a na sua totalidade. Mesmo do ângulo biotipológico, que a muita gente se afigurava coisa tão recente e moderna, o dr. 'Mirandela' procurou examinar o problema alimentar, notando que cada temperamento e cada idade deviam ter os seus alimentos. Assim sucedeu com a questão do clima e do horário da alimentação. Portanto, para Peregrino Junior (1941), o dr. 'Mirandela' foi o precursor da higiene entre o povo daqui, pois havia um elo de continuidade entre a sua cartilha e os estudos de higiene até então desenvolvidos, como o do dr. Sinval Lins, por exemplo, que foi quem melhor compreendeu, aqui, o problema da alimentação nos climas tropicais, defendendo também os postulados higiênicos da sobriedade, da moderação, do equilibrio alimentar:

Esse 'Antelóquio', que o Mirandela pôs no pórtico da sua 'Ancora Medicinal', coloca em equação todos os problemas que preocupavam os médicos e os higienistas daqueles bons velhos tempos de D. João V. E de certo modo alguns dos têrmos dessa equação continuam ainda agora a constituir objeto das cogitações de higienistas e médicos do nosso tempo. De resto, o que caracterizava, de modo geral, a orientação de Francisco da Fonseca Henriques era um princípio comum de sobriedade e moderação, que continua a ser até hoje a boa norma fundamental da arte de viver com saúde. (Peregrino Junior, 1941:33-34)

Desse modo, o autor sintetizava as idéias do dr. Mirandela:

- a alimentação devia ser sóbria e escolhida;

- a alimentação devia ser ministrada com caráter individual, de acordo com a idade, o tipo constitucional e o sexo de cada pessoa; 
- a alimentação devia ser adequada às estações e ao clima;

- cada pessoa devia comer no horário que melhor lhe conviesse, mas sem esquecer que a digestão tinha um ritmo que cumpria respeitar; $e$

- a sobriedade em tudo; a moderação no comer e viver; o harmônico equilíbrio entre o repouso e o trabalho, entre o sono e a vigília; o domínio das paixões, para que não alterassem a harmonia dos humores - eis as condições fundamentais da vida longa e da saúde.

Quem severamente obedecesse na vida a essas diretrizes, ao que dizia o dr. Mirandela, não podia deixar de ter boa saúde, ou ao menos não teria tantas ocasiões de a perder.

Quanto a esse aspecto, a higiene alimentar, embora não tenha recebido uma denominação precisa na obra de Peregrino Junior (1941), era apresentada como tal em seus componentes temáticos básicos: como se alimentam as nossas classes armadas (soldados e marinheiros); doenças de carência; determinação do padrão dietético nas diversas regiões; política alimentar brasileira; valor social e econômico da alimentação; conseqüências da má alimentação; a subnutrição e o tipo físico da raça; alimentação e estatura: no Japão e na China; a experiência da Grande Guerra, os desempregados nos Estados Unidos e a fome na Rússia, os pigmeus; observações realizadas no Rio de Janeiro; alimentação e pauperismo; sentido político do problema alimentar; a alimentação nas classes abastadas; a alimentação nas classes proletárias; crianças e adultos.

Pode-se concluir daí que houve de fato uma produção articulada e unitária em torno da definição do campo da higiene alimentar no que se refere à composição do seu campo temático, não obstante a evidência de duas tendências diferençadas nesse processo: uma, que vinculava a educação alimentar à higiene alimentar (Veloso, 1940), e outra, que definiu o campo da higiene alimentar de modo particular e autônomo, não concebendo a educação alimentar no seu âmbito (Siqueira, 1940 e Peregrino Junior, 1941). A tomar por referência a própria definição de higiene alimentar como a razão de ser da ciência da nutrição e campo de aplicação da fisiologia como espaço de sistematização de um conjunto de preceitos a serem buscados em todos os campos do conhecimento, para além da medicina, é possível compreender a amplitude de abordagens que envolve o conjunto de temas constituidores desse campo, ficando evidente a sua característica inter e multidisciplinar. Significa dizer que vincular a educação alimentar ao campo da higiene alimentar era subordiná-la aos desígnios dos múltiplos enfoques desse campo, assegurando uma visão ampliada dessa modalidade educativa, embora Veloso (1940) preservasse as características centrais que uniram o grupo fundador em torno da sua constituição: a ignorância 
como matriz justificadora do seu sentido, os temas do seu âmbito, bem como a definição dos procedimentos e recursos pedagógicos orientadores de um plano de ensino da alimentação em três níveis - escola primária, escola secundária e universidades. Tal tendência abrangente traz elementos importantes, como será visto adiante, para o entendimento do alcance da educação alimentar como um campo disciplinar específico, centrado essencialmente nos procedimentos e recursos pedagógicos pelos quais os preceitos da higiene alimentar seriam difundidos.

\section{Dietética e dietoterapia: a disciplina do prazer e do gosto}

Na visão de Veloso (1940), a dietética ou dietologia era a parte da alimentação que se ocupava da prescrição racional e científica da dieta ou regime ou ração a todo e qualquer ser humano. Nesse 'todo e qualquer ser humano' estavam compreendidos adultos de ambos os sexos, crianças, velhos $e$, finalmente, toda sorte de doentes. Na justificação da importância dessa matriz disciplinar, como será visto, marcava presença definitiva no conjunto da produção as idéias de Escudero e interlocutores americanos. Quanto a isso, Veloso (1940:337) transcrevia a definição de Escudero pela qual "A dietética é uma ciência nova, cujos primeiros passos se iniciaram há cincoenta anos atrás, mas que adquiriu uma importância científica, social e econômica imensas só nos últimos vinte anos".

Isso evidencia que é fundamental para o entendimento da definição dos distintos campos disciplinares da nutrição, incluindo a educação alimentar, a síntese operatória e precisa do objeto elaborada por Veloso, quando definia que:

A 'fisiologia', compreendendo a 'biofísica e a bioquímica', como já vimos, trata de toda sorte de transformações, reações e funções dos alimentos no organismo; a 'higiene', de posse dos ensinamentos da fisiologia e outros mais, traça o conjunto daqueles preceitos que devem orientar a verdadeira alimentação racional e sadia; e a 'dietética', finalmente, com a colaboração de uma e de outra, põe em prática, realisa e executa tudo aquilo que a higiene, apoiada na fisiologia, prescrevera e ensinára. (Veloso, 1940:337)

Nisso residia o avanço que, na época, assumia o estudo da dietética em muitos países, onde o problema da alimentação racional do homem cada dia mais se desenvolvia dentro de uma orientação absolutamente científica. Para esse autor, somente naquele momento (1940) começava realmente a preocupação com o estudo das disciplinas que facilitariam o conhecimento, a exploração e o manejo dos alimentos, afirmando a esse respeito: 
Daqui a alguns meses sairá, do Serviço de Alimentação da Previdência Social recentemente, criado por ato do atual governo, a primeira turma de 'dietistas brasileiros', com capacidade técnica suficiente para organisar e dirigir qualquer secção de economia doméstica, seja em fábricas, colégios, restaurantes, hospitais, asilos, orfanatos, ou quaisquer outros departamentos análogos. É este, incontestavelmente, o primeiro passo sério que se dá no terreno da prática, para melhoria das condições de alimentação individual e coletiva no Brasil. (Veloso, 1940:338)

Conforme o documento da Associação Brasileira de Nutrição (1991), antes mesmo da criação do SAPS (agosto de 1940), foi organizado o primeiro Curso de Auxiliares de Alimentação no Distrito Federal, em fevereiro de 1940, sob a incumbência de um dos médicos do Instituto de Aposentadoria e Pensões dos Industriários (IAPI), dr. Josué de Castro, com o objetivo de formar recursos humanos especializados para a implementação do Serviço Central de Alimentação. Com duração de seis meses, o referido curso era constituído das seguintes matérias:

- Biologia Geral e Higiene;

- Noções de Química e Laboratório;

- Alimentação e Nutrição;

- Dietética;

- Arte Culinária e Cozinha Dietética;

- Economia Alimentar e Organização de Alimentação Coletiva. ${ }^{23}$

Coincidentemente, embora a Sociedade Brasileira de Nutrição, fundada em 1936, não tenha durado o tempo suficiente para ver realizadas todas as suas aspirações, havia frutificado idéias congêneres no Distrito Federal e nos estados que levaram à fundação da Sociedade Brasileira de Alimentação, em 1940, sob a presidência de Josué de Castro. Como registravam os Arquivos Brasileiros de Nutrição, a Sociedade Brasileira de Alimentação foi concebida como uma agremiação "composta de número ilimitado de associados das diversas classes sociais interessadas no problema da alimentação nacional - nasceu na capital do Brasil, no dia 10 de janeiro de 1940" (Universidade do Brasil, 1944:77).

Evidentemente, tem toda importância registrar e caracterizar as associações e instituições criadas no período de 1940 a 1946, dado que, como bem evidencia o conjunto da produção em foco, a definição dos campos disciplinares no terreno da produção das idéias e a sua institucionalização faziam parte de um só

${ }^{23}$ Foram professores no primeiro Curso de Auxiliares de Alimentação: Adhemar Hooper Pinto, Celina de Moraes Passos, Cleto Seabra Veloso, Dante Nascimento Costa, Hélio Luz, Pedro Alves da Costa Couto, Rubem de Siqueira, Rubens Descartes de Paula, Thalino Botelho e Thomaz de Figueiredo Mendes. (Associação Brasileira de Nutrição, 1991). 
movimento em que os intelectuais eram os principais protagonistas, enquanto buscavam afirmar a identidade do grupo. Não havendo ainda no Brasil cursos de nutrição no nível universitário, os intelectuais não podiam desenvolver a contento as grandes pesquisas projetadas. Assim, na Sociedade Brasileira de Alimentação,

se focalizam as pesquisas mais interessantes realizadas modernamente entre nós no campo da alimentação, muito diferente dos processos difusos, cheios de observações importadas; eivadas de preconceitos e empirismos dos nossos estudiosos de outrora que copiavam tudo, importavam tudo. A verdade é que só agora o nosso país inicia a etapa verdadeiramente cientifica do problema. De 1930 para cá, a história da alimentação no Brasil vem queimando as suas verdadeiras etapas numa verdadeira vertigem criadora. (Universidade do Brasil, 1944:79)

Nesse enfoque, entre as demais etapas percorridas nesse movimento criador, a publicação dos Arquivos Brasileiros de Nutrição (1944) correspondia à etapa de aplicação racional, no campo da produção e do consumo, de métodos e processos técnicos e científicos da ciência da nutrição. Como informam esses Arquivos, a Sociedade Brasileira de Alimentação estava propensa a se tornar um grande centro de estudos, com aplicações sociais intensas dos conhecimentos da alimentação e nutrição. É notório qựe tais etapas guardam toda coerência com a linha interpretativa que se adotou nesse estudo sobre a constituição da educação alimentar.

Quanto a isso, o ano de 1940, ao iniciar o estudo das disciplinas que facilitariam o conhecimento e o manejo dos alimentos, trazia com a definição do campo da dietética a definição de três profissões afins no âmbito da ciência da nutrição dietólogos, dietistas e cozinheiros. Na abordagem de Veloso (1940), para dar cumprimento ao seu vasto e difícil programa de realizações, a 'ciência dietética', em todo o mundo, carecia de um determinado grupo de profissionais e técnicos. Eram os dietólogos, os dietistas e os cozinheiros. O dietólogo era o médico que fazia dietologia; o fisiólogo, a fisiologia; e o bacteriólogo, bacteriologia. E como a dietologia não podia prescindir da fisiologia, da anatomia, da química orgânica e inorgânica, da química biológica, da físico-química, da bacteriologia e da patologia, concluía-se daí que o dietólogo precisava socorrer-se, a cada passo, do conhecimento de todas essas ciências, a fim de poder enfrentar os segredos do organismo no tocante à alimentação. Nesse processo definitório, o autor se inspirava novamente em Escudero, transcrevendo o seguinte trecho da obra Alimentação (1934):

O extenso curso que experimenta o alimento após a absorção, se designa com uma só palaura - 'metabolismo'. Conclue-se, pois, que um dietólogo deva ser 
um fisiologista, capaz de compreender as misteriosas transformações do alimento ingerido. Aquilo que não fôr utilizado é eliminado, podendo resultar perturbações da saúde só conhecidas do médico, se a alimentação se processar de modo irregular e incompleto. Sómente os médicos entendem de dietologia; os químicos, físicos, bacteriólogos e fisiólogos emprestam também sua colaboração; porém, juntos ou separados, não podem ser dietólogos. (Veloso, 1940:339)

Sendo o campo da dietética o espaço da prática, realizando e executando o que a higiene e a fisiologia prescreveram e ensinaram, como definia Veloso (1940), e sendo a alimentação um fenômeno social a ser examinado sob esse aspecto, a formação especializada era uma das primeiras condições para assegurar a cientificidade da alimentação. Nessa perspectiva, para o autor, como o farmacêutico era o traço de união entre o médico e os medicamentos, o dietista era o traço de união entre o dietólogo e os alimentos, sendo considerável a importância disso. Bastava lembrar que na América do Norte a profissão de dietista era tão importante que na época não existia hospital, beneficência, asilo, orfanato, escola, hotel ou restaurante que não possuísse um dietista encarregado da seção de economia doméstica. "Como diz Escudero, o "dietista é um farmaceutico que ao invés de lidar com os remédios trata dos alimentos". Para Veloso (1940:339), nesse sentido, a missão do dietista estava tanto no que dizia respeito ao preparo dos alimentos para os doentes, como para as pessoas sãs. Ambos precisavam do dietista.

Em tempo, fica evidente que Carmo (1942), ao configurar o ensino da nutrição na formação do médico em meio à definição do campo disciplinar da fisiologia, como se viu, seguia a trilha de Veloso (1940). Este autor, ao definir o campo disciplinar da dietética, anunciava que o dietólogo/nutrólogo era um fisiologista que devia compreender todas as transformações pelas quais o alimento passava no organismo e tratar das patologias a ele relacionadas, de onde se deduz que a sua formação deveria assegurar a competência necessária para o exercício da prescrição da dieta. Com isso, o dietólogo se distinguia dos químicos, físicos, fisiólogos, bacteriólogos.

Nisso reside toda a diferença na formação do dietólogo e do dietista. Sendo o dietista concebido como auxiliar do dietólogo, sua formação só poderia estar no âmbito da dietética como campo de aplicação da fisiologia, embora a sua missão estava na organização e produção de rações balanceadas para pessoas sãs e pessoas doentes. Se o dietista, em vez de lidar com os remédios, como o farmacêutico, lidava com os alimentos, sua formação devia assegurar capacidade técnica para organizar e dirigir, como afirmava Veloso (1940), a seção de economia doméstica, a qual se caracterizava pela produção de refeições balanceadas em fábricas, colégios, restaurantes, hospitais etc. e, por conseguinte, 
orientar e administrar a cozinha dietética. Disso se depreende que ao médicodietólogo ficava assegurada não somente a missão de prescrever a dieta e corrigir as patologias a ela subjacentes, mas também de continuar a produção de pesquisas, conceitos, teorias sobre alimentação e nutrição, mantendo o domínio desse campo do saber, e ao dietista cabia absorver o instrumental técnico criado nesse campo para o exercício da dietética. Não se conclua, com isso, que o médico não precisava estudar a dietética nem o dietista a fisiologia. Esta última era o campo definidor da identidade do dietólogo/nutrólogo, enquanto a dietética definia a identidade do dietista (que foi, posteriormente, denominado nutricionista). É, portanto, nesse processo histórico que reside a resposta à polêmica atual sobre a identidade da profissão do nutricionista e sua formação universitária, e menos na interpretação do seu currículo atual e sua prática. Em bases empíricas e conceituais agora sabe-se de onde viemos. No entanto, fica também visível que a dietética, como núcleo de identidade da ciência da nutrição em construção, não se afirmava em bases estritamente técnicas, fisiológicas, mas sob orientação social.

Para isso, era preciso também operar com a distinção entre cozinha dietética e arte culinária, entre a especialidade e função do dietista e a do cozinheiro. Havia a cozinha que Veloso chamava trivial, que se ocupava da alimentação das pessoas sãs; a cozinha de luxo, em que comandava um prazer - a glutonaria - e, por fim, a cozinha dietética, sobretudo individual,

onde ao lado dos conhecimentos banais de toda arte culinária, vem se colocar a verdadeira dietética, com tôdos os ensinamentos científicos indispensáveis à arte de bem se alimentar, à prescrição de regimes e ao aproveitamento perfeito dos alimentos. Esta nova cozinha, onde podem trabalhar vários cozinheiros, deve ser orientada e dirigida sempre por um 'dietista'. (Veloso, 1940:339)

Desse modo, como o dietista era o auxiliar do dietólogo, o 'cozinheiro' poderia ser o auxiliar do 'dietista'. E o era, com efeito:

Dado o desenvolvimento em tôdo o mundo, do estudo da alimentação nêstes últimos anos, quando já se define o papel dos dietólogos e que acaba de surgir a nova função de dietista - é justo que a profissão do 'cozinheiro' se oriente também num sentido novo, onde o empirismo de tantos séculos deva ceder lugar aos ensinamentos da verdadeira arte culinária. Ainda hoje, em muitos países, a cozinha é considerada lugar indesejável, e como tal, entregue sempre aos cuidados da ralé, de pessôas atrazadas e ignorantes dos mais comezinhos preceitos de higiene. São os 'cozinheiros' ou 'cozinheiras' quem as dirige a seu bel prazer. São autoridades ali dentro: 'temperam', 'retemperam', 'misturam', 'cozem', 'aferventam', 'intoxicam', 'envenenam' e até 'matam', com os agradecimentos e aplausos de tôdos que os seus bons pratos saboreiam. (Veloso, 1940:340) 
Para esse autor, ninguém queria saber o que era a cozinha entregue a mãos ignorantes e incapazes. Só o que se exigia era que o prato estivesse gostoso, saboroso e de forma surpreendente, embora desastrosamente temperado, incompleto e anti-higiênico. Por isto, devíamos ter em nossas cozinhas pessoas sãs, com noções reais de higiene, cuidadosas no preparo dos alimentos e, sobretudo, compenetradas da importância da missão que exerciam em relação às vidas alheias.

A respeito da dietética, é necessário assinalar que havia evidentes aproximações entre os autores quanto aos postulados fisiológicos, bem como às regras da dietética, mas diferenças quanto à sua configuração como matriz disciplinar, tendência essa compreensível no momento em que internamente se operava a definição da base cognitiva dos diversos campos disciplinares, cabendo aqui a advertência de que tal processo não deve ser confundido com planos e programas institucionais de disciplinas, ainda que são instâncias diferentes de produção. O que está em questão aqui é a forma como os explicadores conceberam as bases cognitivas e instrumentais da educação alimentar à caça da sua identidade, embora estivesse em pauta, é claro, a perspectiva da sua institucionalização como campo de ensino e atuação.

$\mathrm{Na}$ abordagem de Veloso (1940), a dietética se iniciava pela definição da ração alimentar à qual correspondia a quantidade e qualidade de alimentos que devia receber cada pessoa durante 24 horas, a fim de manter equilibrado o seu organismo dentro de um nível ótimo de saúde. Para que o conjunto das funções orgânicas não se perturbasse em momento algum, era necessário que não faltasse à ração, em quantidade e qualidade, qualquer das substâncias de que o organismo necessitava - proteínas, hidratos de carbono, gorduras, água, sais minerais e vitaminas. Essa ração alimentar, que se destinava a cobrir as necessidades nutritivas do organismo, era calculada de acordo com os seguintes dados: idade do indivíduo, peso, altura, clima, atividade corporal, estado fisiológico. A definição de dietética incluía não somente os princípios fisiológicos, mas também os instrumentos e modos de cálculo da ração racional, bem como a elaboração de regras e conselhos.

Sob esse enfoque, a dietética estava voltada para a alimentação do operário, restaurantes e cozinhas coletivas, a alimentação da criança desde o nascimento até os 16 anos, a alimentação da gestante e a alimentação do velho. Embora essa tendência a contemplar as diversas fases da vida seja expressiva no conjunto das obras, a considerar até mesmo o período anteriormente analisado nesse trabalho (1934 a 1939), o escolar e o operário foram os dois segmentos sociais que receberam ênfase em todos os temas abordados pelos autores, 
prioridade como destinatários dos diversos planos propostos de uma educação alimentar, mesmo quando esta tinha caráter de universalidade:

A alimentação é, como se vê, a condição número 1 para que o trabalho do operário - trabalho que representa juro de capital - seja realmente produtivo e eficiente. Ao seu lado é que vêm, em segundo plano, o conhecimento técnico, a inteligência e demais fatores responsaveis pelo maior ou menor exito de qualquer trabalho. (Veloso, 1940:363)

Cabia à dietética dosá-las em razão de cada caso. Essa era, de resto, a missão dos dietólogos e dietistas, auxiliados pelos cozinheiros, pois:

Para que a criança brasileira se desenvolva forte e sadia, preservando-se de uma série de doenças e táras orgânicas adquiridas justamente na idade escolar, é necessário que a sua alimentação reuna os predicados acima. Disso devem estar convencidos os pais e os professores, ambos responsáveis pela formação da criança na escola. (Veloso, 1940:375)

Mas a dietética, como campo disciplinar, não se limitava apenas a ditar as regras da ração normal. Veloso (1940:387) definia também que a "dietoterapia é a parte da dietética que tem por objeto o tratamento do indivíduo por meio da diéta ou regime". O termo dietoterapia não implicava absolutamente restrição, como também não era corolário de superalimentação. Tanto se fazia dietoterapia prescrevendo-se regimes restritivos, até a cura, como também adotando-se regimes hipernutritivos, em circunstâncias diferentes. O essencial era que todos soubessem que a arma da dietoterapia era sempre o regime alimentar.

Para fins didáticos, os regimes alimentares podiam ser classificados em regimes gerais, aplicáveis a diversas espécies de doenças, às vezes muito diferentes, e em regimes especiais, aplicáveis somente a uma categoria bem definida de estados mórbidos. Quanto a isso, o autor apresentava um quadro geral com a classificação dos principais regimes alimentares: os regimes gerais compreendiam regimes de superalimentação e regimes de restrição. Os regimes especiais eram regimes das doenças da nutrição e outras afins.

Nessa perspectiva, a dietoterapia deveria ter como programa de estudo várias modalidades de regimes. No plano dos regimes gerais, os regimes de superalimentação compreendiam: regime hiperprotéico, regime hipergorduroso e regime hiper-hidrocarbonado. Ainda nesse plano, os regimes de restrição compreendiam: curas de jejum, com dieta hídrica, regimes secos, regime hipoprotéico, regime hipogorduroso, regime hipohidrocarbonado, regime zig-zag, regime descloruretado, regime lácteo exclusivo e misto, regime vegetariano exclusivo e misto, e regime de eliminação. Os regimes especiais compreendiam: do diabético, do obeso, dos cálculos, do gotoso, do magro, do hipertenso, do hepático, do ulceroso, do gástrico, do cardíaco, do renal, do intestinal e outros (Veloso, 1940). 
Com isso, Veloso detalhava os pontos de estudo da dietética - arte culinária -, cozinha dietética, mantendo a ordem de seqüência iniciada com a fisiologia:

30 Ponto - Definição de dietética. Sua importância. Dietólogos, dietistas e cozinheiros. A cozinha dietética.

31 Ponto - Da ração alimentar (Dieta). Fatores qualitativos. Como se calcula uma ração alimentar. Fatores quantitativos.

$32^{\circ}$ Ponto - Alimentação do homem normal. Seus principais componentes. Relação nutritiva. Tipos de cardápios.

33Ponto - Alimentação do operário. Suas necessidades energéticas. Alimentos indispensáveis ao operário. Restaurantes e cozinhas coletivas.

34ํPonto - Alimentação da criança. Alimentação do lactante. Alimentação no $2^{\circ}$ ano de vida. Alimentação na idade escolar.

35 Ponto - Alimentação da mulher grávida. Suas necessidades energéticas e plásticas. Tipos de regimes.

36오 Ponto - Alimentação do velho. Suas necessidades energéticas. As refeições do velho.

37 Ponto - Das substituições de alimentos em face da economia.

38 Ponto - Da dietoterapia. Principais regimes alimentares. Regimes de superalimentação e regimes de restrição.

39 Ponto - Regime alimentar nas doenças da nutrição.

$40^{\circ}$ Ponto - Regime alimentar nas doenças do aparelho digestivo.

41ํ Ponto - Regime alimentar nas doenças do aparelho circulatório e dos rins.

$42^{\circ}$ Ponto - Regime alimentar nas doenças infecciosas e de outras afins.

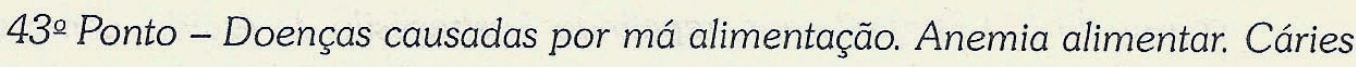
dentárias. Fosfatúria, oxalúria, uratúria. Acidose. Obesidade. Gota. Calculose e outras. (Veloso, 1940:terceira parte)

Diferentemente de Veloso, a Dietética, na visão de Siqueira (1940) estava voltada apenas para a ração normal: da criança, do escolar, da gestante, do trabalhador, do velho, dos desportistas e das coletividades, não abordando a parte da dietoterapia. No que se referia à alimentação do escolar, esse autor assinalava que:

Antes de mostrar como deve ser feita a alimentação escolar, quero aproveitar a oportunidade para insistir num ponto, merecedor das maiores cogitações dos poderes públicos, dada a sua grande importância social - as múltiplas falhas que encerra a alimentação do escolar brasileiro. Iremos relatar apenas o que acontece em muitos colégios do Rio de Janeiro, à vista de todos...Com os pequenos exemplos daqui, tire quem quiser as conclusões do que deve suceder por esse Brasil afóra... (Siqueira, 1940:113) 
Apoiado nos inquéritos sobre a alimentação feitos nessa cidade por Castro Barreto, Ruy Coutinho e Alexandre Moscoso, Siqueira (1940) assinalava que a maioria dos colégios, sobretudo os religiosos, era o alvo da acusação do descaso com a alimentação do escolar. O inquérito de Castro Barreto atestava, por exemplo, que "num internato de religiosas, nos subúrbios, mais de $50 \%$ das meninas apresentavam, além de anemia notável, os mais potentes sintomas de carencia" (Siqueira, 1940:113). Esse problema, que era muito grave quando se tratava de adultos, tornava-se extremamente delicado quando se referia às crianças. Quanto a isso, o autor destacava que os fins comerciais daquelas casas de ensino ressaltavam à primeira vista, pois, num grande colégio de Botafogo, informava Castro Barreto, a merenda compunha-se de uma fatia de salame com pão. Um outro colégio, do mesmo bairro, apresentava sempre, invariavelmente, como prato central, no almoço, um picado de carne seca: Aliás,

A coisa mais difícil no mundo é conseguir fazer um inquérito nos colegios particulares do Rio de Janeiro, em regime de internato ou semi-internato. Com raríssimas excepções, todos eles fogem ao inquérito e, muitos deles, quando prestam informações, fazem-nas mentirosamente. Rarissimos são os colegios particulares que apresentam Corpo Médico encarregado de fichar os alunos e prescrever dietas apropriadas. Para que? perguntam os diretores desses 'educandários'. O grande espirito idealista e social dessa gente está na barriga e na bolsa. E desafio a quem quer que seja para provar o contrário. O regime da maioria dos colégios do Rio de Janeiro é o de 4 refeições indistintamente para os meninos de 5 anos e os rapazes de 15 a 18 anos. As refeições são de uma monotonia horrenda; não ha variações na composição e no horário da distribuição (...) A qualidade dos alimentos fornecidos e, via de regra, para causar dó (...) Perguntamos, repetindo Austregésilo de Ataíde, como tirar de crianças maltratadas dessa maneira uma geração enérgica e empreendedora, como o Brasil tanto necessita? (Siqueira, 1940:116)

Nesse sentido, vale destacar que se instalava, de fato, no ano em foco, a política de alimentação escolar no Distrito Federal, pois esse autor comentava em sua obra as instruções baixadas pelo Ministro Gustavo Capanema, em meados daquele ano, relativas ao regime higiênico-dietético dos internatos e semiinternatos de estabelecimentos de ensino secundário e ensino comercial sob inspeção federal. As instruções recomendavam, na parte atinente à alimentação, a inclusão obrigatória de, no mínimo: meio litro de leite diariamente, para os alunos internos, e 250 mililitros para os semi-internos, distribuídos pelas refeições, em natureza ou em mistura com outros alimentos, sob a forma de mingaus, doces, purês; vegetais (verduras e legumes) nas principais refeições, e, onde não houvesse perigo de contaminação, uma das rações seria de verduras cruas (salada 
com limão); frutas, ao menos em duas refeições; ovos (três, no mínimo, por semana), para cada aluno; carne fresca (100 a 200 gramas diários por aluno), devendo ser substituída, ao menos duas vezes por semana, por peixe fresco, fígado ou miolos de galinha; pão (dois, no mínimo, de 100 gramas por dia por aluno) com manteiga, convindo que o pão branco fosse substituído, ao menos uma vez por semana, por pão ou broa de milho, pão preto ou pão integral; queijo, ao menos uma vez por semana; manteiga, duas vezes por dia; feijão mulatinho, manteiga e branco; arroz, de preferência integral, duas vezes por dia; outros cereais como milho, sob a forma de angu, canjica, sopa, bolo, farinha, como ainda aveia, trigo etc. e massas alimentícias, uma vez por dia; um dos seguintes alimentos, em uma das refeições principais: batata inglesa, batatadoce, aipim (mandioca, macacheira), cará, inhame etc.; doces, uma vez por dia no máximo, em uma das principais refeições.

Conforme Siqueira (1940), proibiam tais instruções o uso de qualquer bebida alcoólica, de alimentos preparados ou em conservas como salame, mortadela, salsichas, lingüiça, carne seca, sardinha etc. Desaconselhava o uso de crustáceos (camarão, siri etc.), frituras (pastéis etc.), condimentos (pimenta, pimenta-do-reino, mostarda etc.) e restringia a quantidade de água às refeições. Estabelecia, ainda, as instruções, o horário das refeições:

1. $6 \mathrm{~h} 30 \mathrm{~min}$ às $7 \mathrm{~h} 30 \mathrm{~min}-15 \mathrm{a} 20$ minutos;

2. $10 \mathrm{~h} 30 \mathrm{~min}$ às $11 \mathrm{~h} 30 \mathrm{~min}$ (almoço) - $30 \mathrm{a} 40$ minutos;

3. $14 \mathrm{~h}$ às $15 \mathrm{~h}$ (merenda) - $15 \mathrm{a} 20$ minutos; $e$

4. $17 \mathrm{~h}$ às $18 \mathrm{~h} 30 \mathrm{~min}$ (jantar) - $30 \mathrm{a} 40$ minutos.

No verão, o horário aconselhado poderia ser recuado em uma hora. Além disso, aos alunos ficava vedado qualquer exercício violento (futebol, basquete, vôlei, corrida apostada, salto etc.) meia hora antes e até uma hora após as refeições. Concluía Siqueira (1940) que se essas instruções fossem cumpridas, muito lucraria o colegial brasileiro.

Quanto à alimentação do trabalhador, o autor referendava a definição de Moscoso, segundo a qual trabalhador era todo aquele que produzia, variando a sua alimentação de acordo com a natureza do trabalho - leve, moderado, forte e muito forte. Considerava trabalho leve aquele desempenhado por donas de casa, artistas, empregados de escritório e comércio, relojoeiros, barbeiros, médicos, dentistas, advogados, alfaiates, guarda-livros etc.; moderado, o dos carpinteiros, empregados de fábricas, empregados domésticos, cocheiros, pedreiros etc.; forte, o dos carregadores, lavradores, mineiros, cavouqueiros, ferreiros, calceteiros etc.; e muito forte, o dos estivadores, foguistas, lenhadores etc. 
Nessa perspectiva, a exemplo de Veloso, Siqueira (1940:141) concebia igualmente a fronteira das especialidades/profissões, definindo que o dietólogo era um médico conhecedor da dietologia, tendo como auxiliar principal o dietista, que era, na expressão de Escudero, "um farmacêutico que, em vês de lidar com remédios, trata dos alimentos". Assim "como o farmacêutico é o traço de união entre o médico e os medicamentos, o dietista é o traço de união entre o dietólogo e os alimentos".

Siqueira (1940:141) também promovia a distinção entre cozinha dietética e arte culinária:

Cada estabelecimento coletivo deve ter organizado o departamento das cozinhas com pessoal idôneo, competente. Aliás, a Comissão Técnica do Exército, já citada no decorrer do nosso trabalho, propoz, em 1932, a creação de 'uma escola pratica para cozinheiros', atendendo a que os alimentos, para serem bem aceitos pelo homem e atingirem sua finalidade no organismo, necessitam de um preparo perfeito, racional, de conformidade com os atuais conhecimentos da higiene e da bromatologia.

Aproximando-se mais uma vez de Veloso, este autor assinalava que a profissão de cozinheiro, relegada, no nosso meio, a um plano inferior, devia orientarse, também, pelos progressos da ciência. No nosso país, entretanto, os cozinheiros eram, em geral, improvisados, ignorantes das noções mais elementares de arte culinária, desconhecedores, em suma, dos seus misteres e de suas altas funções.

Para o Exército, Marinha, Corpo de Bombeiros, Hospitais etc., era imprescindível a renovação dos modos de escolha do pessoal destinado às cozinhas. Nisso, Siqueira (1940:142) advertia que falava com conhecimento de causa, pois inúmeras vezes, ao penetrar nas cozinhas de vários estabelecimentos coletivos, tinha verificado, com imensa tristeza, a ignorância crassa dos indivíduos encarregados de cuidar do mais valioso capital nacional - a saúde: "Além disso, as cozinhas estão representadas, quasi sempre, pela clássica posição caudatária dos edifícios, sob puxados, muitas vezes, e sem nenhuma comodidade".

A preocupação de Siqueira com a alimentação racional do Exército se justificava em face da iminência de uma nova guerra, em que os intelectuais deveriam cooperar com o máximo esforço, realizando experiência para fornecer às Forças Armadas do País os elementos químicos necessários ao máximo de rendimento em prol da defesa nacional:

Por toda parte há uma consciência perfeita de que estamos em guerra e que devemos cooperar com o máximo de nosso esforço. O Exército Brasileiro, em sua formidável preparação para fazer face as suas obrigações do momento, não podia esquecer nenhum setor de sua máquina de guerra e a alimentação é uma peça fundamental desta gigantesca engrenagem. (Universidade do Brasil, 1944:77) 
Assim, não se podia compreender, sobretudo quando se tratava de alimentação de coletividades, que se entregasse a pessoas ignorantes e sem competência a elaboração do que mais decisivamente interferia em nossos destinos: a alimentação. Era preciso, então, cuidar também da cozinha e do seu pessoal técnico.

É interessante notar que a revolução alimentar pretendida pela dietética passava, necessariamente, pela superação da arte culinária e instauração da cozinha dietética, à medida que esse assunto foi aprofundado por Veloso (1941), no seu livro A Gastrotécnica na Alimentação Brasileira, caracterizado como um breve ensaio de história social, antropologia e sociologia.

O início da obra trazia à tona um assunto que, segundo Veloso (1941), era considerado prosaico. Em contraposição a essa assertiva, ele começou com uma advertência:

Quem disser que 'culinária' é coisa prosaica; quem disser que quem mexe com 'cozinha' se lambusa, e se rebaixa, e se diminui, - está redondamente enganado. A 'culinária' não interessa somente ao cozinheiro, ao literato ou ao artista e muito menos ao diplomata ou ao político, como até então se supunha. (Veloso, 1941:6)

Ela interessava também ao biólogo, ao médico, ao nutricionista, ao higienista, ao químico, ao físico-químico, ao eugenista, ao puericultor, ao geneticista, ao psicólogo, ao pedagogo, ao folclorista, ao sociólogo, ao filósofo.

Nessa perspectiva, o autor comentava que o Brasil devia ao precursor Gilberto Freyre os melhores estudos publicados até aquele momento. Figuraram também como seus interlocutores na obra em foco Nina Rodrigues, Manoel Quirino, Araújo Lima, Artur Ramos e Sebastião Barroso, que também haviamse dedicado ao assunto. Assim, no primeiro capítulo, Veloso (1941) abordou a importância e a finalidade da arte culinária. Num primeiro ângulo, a culinária representava uma das vitórias do homem sobre a natureza; era a expressão da cultura; era fator de progresso de povos e nações; era finalmente uma arte. Por esse aspecto, a culinária foi enfocada como arte de preparar maravilhas para o paladar do homem - "o único animal que mesmo depois de velho ainda não sabe comer" (Veloso, 1940:12). Era exatamente esse ângulo (a gastronomia) o mais estreito e mais devastadoramente nocivo com que muitos pretendiam justificar as suas verdadeiras finalidades:

Somente a ignorância, a glutonaria, a opsofagia, a gula e o vício podem, com efeito, encontrar motivos ou expressões de arte numa 'feijoada', numa 'bacalhoada', numa 'sopa de peixe' à moda Leão Veloso, 'num bife a cavalo', ou se quiserem (vamos aos 'pratos' elegantes), numa 'lagosta com maionese', 
num 'virado de carangueijos', numa 'galinha à maitre-d'hôtel', num 'pudim San Maurizio', num 'pudim Siciliano', - para citarmos apenas alguns dos milhares de regalos existentes. (Veloso, 1941:12)

Nesse primeiro enfoque da culinária, segundo ele, a ênfase recaiu no aspecto exterior, o cheiro aromático, ou então picante, agressivo, o gosto superagradável e, por fim, o ambiente de sensualismo no qual se processavam de ordinário as refeições que desvirtuavam completamente o ato visceralmente biológico da alimentação. No entanto, para Veloso (1941), naquele momento, as coisas haviam mudado: o sábio e o pesquisador assumiram o governo da cozinha e, aplicando as leis da química e da física, acabaram com o empirismo dos cozinheiros, atribuindo à culinária a precisão de uma arte definida, assim surgindo os dietistas. Naqueles tempos, o dietólogo, o dietista e o cozinheiro formavam, afinal, um trio indispensável à dietética e à dietoterapia.

O segundo ângulo da culinária dizia respeito ao fator higiene. O preparo culinário, com seus processos físicos de cozimento, de fritura, de assado etc., podia remediar e até remover elementos nocivos à saúde, pondo ao alcance do homem alimentos em perfeitas condições de higiene e salubridade. Num terceiro ângulo, a culinária foi enfocada como fator fisiológico, visto que a digestão dos alimentos começava, segundo Veloso (1941), na panela e no forno. O processo de cocção dos alimentos desagregava as moléculas, preparando o alimento para a ação dos sucos digestivos no processo de nutrição. Além disso, havia o fator psíquico da fome, cujo processo era beneficiado com os progressos da culinária, como indicavam os trabalhos de Pavlov. O aspecto exterior das iguarias, o cheiro e o gosto podiam, pois, condicionar reflexos úteis aos fenômenos de secreção, digestão e absorção dos alimentos. Num quarto ângulo, a culinária foi enfocada como fator econômico. Graças aos modernos processos de preparo e conservação dos alimentos, podiam os produtos comestíveis ser guardados, conservados e transportados a grandes distâncias, sem o perigo das deteriorações e com inúmeras vantagens econômicas.

Finalmente, a culinária foi enfocada como fator moral. Na luta pela vida, sujeitos aos imperativos da concorrência vital, os seres vivos se entredevoravam continuamente uns aos outros, vencendo sempre o mais forte, o mais capaz, o mais apto. Para Veloso (1941), isso se afiguraria bárbaro se a matança dos outros seres vivos não se desse longe das vistas; e se, porém, a culinária, agindo nesse caso como verdadeira arte, não se incumbisse de trazer à mesa, nas refeições diárias a que se impunha, os alimentos sob a forma de verdadeiras iguarias. Em síntese, esse autor definiu a arte culinária, modernamente denominada de gastrotécnica ou gastrologia, como a ciência que tinha por objeto 
o estudo dos processos e métodos racionais de preparo dos alimentos, o que resumia os progressos alcançados nessa disciplina naqueles últimos tempos. Quanto a isso, Veloso (1941) reiterava a classificação que já havia feito na sua obra Alimentação (1940), quando reafirmava que havia no Brasil a cozinha de luxo, em que comandava o prazer - a glutonaria; a cozinha trivial, simples e sóbria ao extremo, que era a mais generalizada; e a cozinha dietética, orientada e dirigida pela dietologia, ou ciência dos alimentos. Com isso, definia os pontos de estudo da cozinha dietética, mantendo a ordem de apresentação:

44 Ponto - Da gastrotecnia. Arte Culinária e Cozinha Dietética. A cozinha trivial e a cozinha de luxo. Utensílios de cozinha.

45ํㅗำ Ponto - A cozinha brasileira. Sua formação: contribuição portuguesa, africana, francesa. Tipos de cozinha brasileira: no norte, no sul, no centro.

46ํ Ponto - A necessidade de uma revisão total nos hábitos da cozinha brasileira. O papel dos dietistas, das donas de casa e dos mestres de cozinha: cozinheiros, e cozinheiras.

47 Ponto-Noções de química alimentar indispensáveis à arte culinária. Como devemos lidar higienicamente com os alimentos. $O$ amor e $O$ interêsse pelos alimentos.

48ㅇ Ponto - Prática direta do preparo dos alimentos dentro dos princípios da verdadeira higiene alimentar. Da execução dos cardápios.

49. Ponto - Conhecimento direto dos processos expeditos para aquisição $e$ conservação dos alimentos. Conhecimentos de contabilidade doméstica - organização de orçamentos, registro de receita e despesa; balanços, etc.

50 Ponto - Conhecimento direto da organização de restaurantes populares, cozinhas coletivas, refeitórios em colégios, fábricas, hospitais, quartéis etc. (Veloso, 1940:quarta parte)

Portanto, esse autor fechava sua contribuição, na definição dos campos disciplinares, delineando também os pontos do ensino prático, os quais não serão aqui detalhados, dada a sua extensão. No entanto, pode-se assegurar que tais pontos se constituíam, em sua totalidade, em práticas laboratoriais relacionadas em sua maior parte com as dosagens bioquímicas, a práticas ligadas à fisiologia e à parasitologia.

Diferentemente dos autores citados, Peregrino Junior (1941), no seu livro Alimentação: problema nacional, não esteve preocupado em delimitar internamente os campos disciplinares nem tampouco as fronteiras de especialidades/profissões. No entanto, sua contribuição no campo da dietética, no período de 1940 a 1946, não pode ser desprezada, na medida em que contribuiu 
para o entendimento das regras preconizadas para a dietética, a serem incorporadas pela educação alimentar. Ao estudar, a exemplo de Siqueira, a alimentação das Forças Armadas (soldados e marinheiros), lembrava que a ração alimentar devia representar, como já afirmara Moscoso, uma 'unidade de alimentação' que, com base no que recomendava o Bureau of Home Economics, comportava: 3 mil calorias, 70 gramas de proteína, $0,68 \mathrm{~g}$ de cálcio, $1,32 \mathrm{~g}$ de fósforo, $0,015 \mathrm{~g}$ de ferro, 8.400 unidades internacionais de vitamina A, 150 unidades internacionais de vitamina C. Assim, segundo esse autor, as rações organizadas para as coletividades tinham por base a quota diária necessária para o homem médio, daí deduzindo-se facilmente as atribuídas aos menores, com o auxílio de coeficientes já determinados.

Segundo ele, as comissões técnicas da Liga das Nações, do Ministério Britânico de Saúde, a comissão consultiva de nutrição da Sociedade Real de Medicina da Grã-Bretanha, o Departamento de Saúde dos Estados Unidos, o Instituto de Nutrição de Tóquio, entre outros, concordavam unanimemente que a necessidade diária de um trabalhador adulto era de 3 mil calorias por dia, fornecidas por uma alimentação que contivesse proteínas, das quais $1 / 3$ devia ser de origem animal, gordura, vitaminas A-B-C-D e cálcio, ferro e fósforo nas quantidades anteriormente indicadas. Quanto a isso, as quantidades de proteínas e gorduras eram uma quota fixa, não oscilando nem variando com as exigências ocasionais do trabalho: as diferenças calóricas decorrentes dessas flutuações eram asseguradas exclusivamente pelos hidratos de carbono, como complemento adicional às calorias necessárias às diferentes atividades musculares.

Objetivando a sua exposição, Peregrino Junior organizou um exemplo de ração semelhante à do operário, proposta por Moscoso, utilizável por um soldado no Rio, nas condições normais de trabalho da caserna, com as diferentes quotas de elementos nutritivos, sendo seu teor calórico 3.018, e seu custo médio, 3\$800. Com isso, ele chegava às regras básicas da dietética para uma orientação correta em matéria de programa alimentar. Em primeiro lugar, uma boa ração alimentar devia obedecer a cinco regras fundamentais:

- o alimento devia ter bom aspecto e bom cheiro, para estimular a secreção gástrica;

- a ração devia ser variada, para evitar a monotonia e a conseqüente inapetência;

- a ração devia conter celulose (frutos, vegetais) para impedir a prisão de ventre;

- o alimento devia saciar a fome e devia conter vitaminas e sais minerais, além de proteínas, gorduras e hidratos de carbono; e

- a ração devia ser suficiente, completa e harmônica. 
Para o autor em foco, a propósito, aconselhava Moscoso judiciosamente: a ração alimentar devia proporcionar diariamente uma série de substâncias energéticas-protetoras - construtoras e ativadoras que caracterizavam a ração mista. Em segundo lugar, as rações deviam variar em virtude do clima, das estações, da idade e do trabalho.

Outro assunto a este relacionado era o do horário das refeições nos climas quentes e nas estações frias. De um modo geral, devia haver um intervalo de três a quatro horas, entre as refeições, levando-se em conta quatro refeições por dia. Segundo Peregrino Junior (1941), Sinval Lins já havia proposto para o Brasil este horário: às 8 horas, almoço; às 12 horas, saladas, frutas; às 16 horas, lanche; e às 20 horas, jantar.

Tal horário, aliás, consentâneo com o ritmo do nosso clima - porque evitava que se almoçasse à hora de mais áspero calor - já era empiricamente adotado pelas velhas famílias rurais do Nordeste. Numa grande cidade moderna como o Rio, porém, é evidentemente difícil transformar assim, de modo radical, os hábitos da população. E o hábito, em alimentação como em tudo, é fator que não se pode esquecer nem suprimir. (Peregrino Junior, 1941:81)

Em vista disso, o autor referendava a seqüếncia das refeições aconselhada por Moscoso para o nosso clima e para os trabalhadores, cuja chegada ao emprego fosse depois das 10 horas: 1 a refeição: 8 horas - alimentação farta e principal; $2^{\mathrm{a}}$ refeição: 12 horas - alimentação ligeira; $3^{\mathrm{a}}$ refeição: 15 horas alimentação ligeira; e 4a refeição: 19 horas - alimentação farta, complementar da 1․ Para os que tinham de estar no local de trabalho às 8 horas, era aconselhável o seguinte horário, que, para esse autor, poderia também ser o dos quartéis: $1^{\text {a }}$ refeição: 6 horas - alimentação ligeira; $2^{a}$ refeição: 10 horas - alimentação farta e principal; 3a refeição: 14 horas - alimentação ligeira; e 4a refeição: 18 horas alimentação farta, complementar da 1ª Além disso, era necessário conhecer e utilizar alguns alimentos brasileiros de primeira ordem e, nesse sentido, o professor Moura Campos, de São Paulo, no seu Laboratório de Fisiologia, tinha estudado muitos alimentos característicos daqui do Brasil, até mesmo a farinha de mandioca, o mate, a banana etc. Em terceiro lugar, era indispensável levar em conta, na elaboração dos programas gerais de alimentação para as Forças Armadas, as peculiaridades econômicas e as diferenciações regionais dos hábitos de vida de cada zona geográfica do País.

Enfim, diante das deficiências porventura existentes de um ou outro dos alimentos propostos, poder-se-ia recorrer aos equivalentes, sendo esta uma regra de dietética postulada por todos os autores os quais apresentaram, após a composição da ração-padrão, uma lista de alimentos substitutos ou equivalentes. 
Quanto a isso, havia alimentos essenciais que não deviam ser substituídos: leite, manteiga e ovo. Mas havia alimentos essenciais que podiam ser substituídos: legumes e frutas. Os alimentos substitutivos eram os que tinham, pelo menos, uma das principais substâncias nutritivas, em quantidade aproximada - proteína - hidrato de carbono - gordura - mineral - vitamina. Ex.: carne de vaca por fígado fresco, peixe por tartaruga, batata por mandioca etc. (Peregrino Junior, 1941).

Os equivalentes eram os alimentos que supriam outros em cifra capaz de garantir determinada quantidade de um alimento nutritivo. Ex.: 60 gramas de camarão seco por 100 gramas de carne de vaca equivaliam-se na quantidade de proteína; 100 gramas de carneiro por 100 gramas de porco fresco equivaliamse na quantidade de gordura. Com isso, o referido autor apresentava uma lista de alimentos equivalentes (Peregrino Junior, 1941).

Em quarto lugar era prudente lembrar, na visão do autor, que qualquer modificação dos hábitos alimentares de uma coletividade devia ser precedida de uma campanha preparatória de persuasão e esclarecimento, sendo aconselhável realizar palestras a respeito nos quartéis e nos navios para que soldados e marinheiros compreendessem as vantagens dos regimes novos de sua alimentação. Nas paredes dos refeitórios deveriam ser colocados cartazes sugestivos sobre nutrição e alimentação, legendas elucidativas, conselhos úteis e simples, frases instrutivas. Finalmente, em quinto lugar, não devia ser esquecido o tríplice objetivo da alimentação: objetivo higiênico, econômico e social. Higiênico - preservando a saúde, evitando a moléstia, assegurando robustez e capacidade física; social reduzindo a mortalidade e a invalidez, aumentando a capacidade reprodutora e, por conseguinte, fazendo crescer a população; e econômico - assegurando ao homem maior aptidão para o trabalho, o que aumentava a capacidade coletiva de produzir riqueza e o poder aquisitivo do indivíduo, enriquecendo o País.

Nesse processo de sistematização do campo disciplinar da dietética, Carmo (1942) se aproximava novamente de Veloso, definindo a dietética como o ramo do conhecimento subordinado às regras da fisiologia tanto na determinação da alimentação do indivíduo sadio como do enfermo. Para cada uma destas rubricas concorriam fatores próprios que davam à dietética características especiais. Para Carmo (1942), o conceito de alimentação, do ponto de vista da fisiologia, foi perfeitamente estabelecido por Armand Gautier, no começo deste século, como tendo por objetivo nutrir os órgãos e mantê-los em regular funcionamento.

No estado de saúde, os fatores a serem levados em conta deveriam ser: a idade, o clima, a estação do ano e o gênero de vida. Esses dados eram influenciados por outros, preponderantes, tais como: de um lado, os recursos 
econômicos, e, do outro, a educação. Com isso, a alimentação tinha por finalidade satisfazer três ordens de necessidades orgânicas:

- despesas de fundo - correspondentes às trocas mínimas indispensáveis (confundem-se com o metabolismo basal);

- despesas de trabalho - variáveis nas atividades e espécies de trabalho a executar; e

- despesas de crescimento - ou de manutenção, variáveis nas diversas fases da vida.

Nesta visão, o organismo utilizava os princípios alimentícios e, pelas suas trocas com o meio externo, assegurava o equilibrio metabólico, satisfazendo as necessidades orgânicas.

Foi com essa obra de Carmo (1942) que se consolidou nitidamente a passagem e a importância de Pedro Escudero na atividade científica do grupo intelectual em apreço, na medida em que o autor sistematizou as bases fisiológicas da alimentação, citando as quatro leis fundamentais formuladas por Escudero, denominadas Leis de Escudero, consideradas conexas e concordantes, tanto no que se referia à alimentação do indivíduo sadio, como na alimentação hospitalar:

$1^{a}$ - Lei da quantidade. 'A quantidade da alimentação deve ser suficiente para cobrir as exigências calóricas do organismo e manter o equilíbrio do seu balanço'

$2^{a}$ - Lei da qualidade. 'O regime alimentar deve ser completo em sua composição, afim de oferecer ao organismo, como unidade indivisível, todas as substâncias que o integram'.

$3^{a}$ - Lei da harmonia. 'As qualidades dos diversos princípios que integram a alimentação devem guardar uma relação de proporção entre si'.

$4^{a}$ - Lei da adequação. 'A finalidade da alimentação está subordinada à sua adequação ao organismo'. (Carmo, 1942:341)

A dietética, ao se subordinar às bases fisiológicas da alimentação, definia regras que dependiam do conhecimento do valor nutritivo dos alimentos, sua composição química, suas combinações na dieta. Outros princípios apoiavamse no próprio indivíduo, no seu biotipo e necessidades orgânicas.

A exemplo de Veloso, Carmo (1942) também tratou da dietoterapia, definindo as suas bases e pontos de estudo. Para ele, desde a época de Galeno que a alimentação do doente era tida em grande conta. Aqui no Brasil, o autor assinalava que a alimentação do doente nunca foi desprezada. Bastava recorrer aos velhos escritos nacionais, como os de Silva Lima, Sá Pereira, Hilário de Gouveia e Torres Homem. Segundo Carmo (1942), este último, referindo-se à orientação clínica do seu tempo (1877), e considerando a febre tifóide, dizia que 
não consentia que o convalescente fizesse uso senão dos alimentos de forma líquida, ou semilíquida, de fácil digestão, e que encerrassem em pequena quantidade os princípios plásticos; o leite, os ovos quentes, os mingaus de farinha de trigo, sopas, ou caldos concentrados, geléias animais, extrato de carne ou pó de carne eram os alimentos a que ele dava preferência, associando-lhes o vinho e o café.

Nesse enfoque, o doente precisava manter, tanto quanto possível, o seu estado de nutrição, as suas forças, para poder se opor às agressões dos estados mórbidos. Considerando que as suas atividades se reduziam de modo sensível no período da moléstia e, que por sua vez, os gastos orgânicos eram mais suaves, sua dieta podia ser simplificada e amoldada em virtude dos efeitos terapêticos que se desejasse obter. De acordo com Carmo (1942), do ponto de vista da alimentação, podiam os doentes ser classificados conforme orientava Escudero:

12 - doentes com os aparelhos digestivo, circulatório e renal funcionalmente sãos. Comuns aos hospitais gerais;

$2{ }^{\circ}$ - doentes do tubo digestivo e glândulas anexas, fígado, vesícula e pâncreas;

3o-febriciantes agudos, traumatizados, pré e pós-operatório. Excitados e deprimidos;

$4^{\circ}$ - doentes do metabolismo: diabéticos, gotosos, obesos; desnutridos e avitaminósicos;

$5^{\circ}$ - doentes dos rins em estado grave e cardíacos em assistolia; $e$

$6^{0}$ - doentes em transição (aqueles que não receberam diagnóstico).

No primeiro grupo, era normal o regime, havendo apenas preocupação por parte do médico em relação ao bem-estar geral e ao peso do paciente. No segundo, havia exigências particulares quanto à preparação e distribuição dos alimentos, que tinham finalidades também terapêuticas (dietoterapia), donde a necessidade de harmonizar os fatores quantidade, qualidade e combinação, em relação aos casos individuais. No terceiro grupo havia necessidade, sobretudo, de tornar o regime adequado ao caso clínico. Os doentes do metabolismo, embora menos numerosos, eram os mais delicados, pelas exigências quantitativas e qualitativas, cuja precisão era a garantia do êxito da dieta.

Portanto, as modificações por que passava uma dieta a fim de preencher os objetivos da terapêutica eram para:

- tornar mais fácil a digestão dos alimentos, sem sobrecarregar o trato digestivo (dietas líquidas, semilíquidas e pastosas);

- visar o repouso de determinado órgão: exclusão de gordura (fígado), proteínas e sais (rins); 
- ajustar a dieta aos desequilíbrios metabólicos, como no diabetes, na obesidade etc.;

- obter ação terapêutica: dieta cetogênica (epilepsia), dieta laxativa (prisão de ventre) etc.;

- corrigir um estado carencial: escorbuto (vitamina C), beribéri (complexo B), raquitismo (vitamina $\mathrm{D}+$ cálcio + luz) etc.; $e$

- aumentar ou diminuir o peso: regimes de engorda e de emagrecimento.

Qualquer que fosse, porém, o motivo que presidisse a feitura de uma ração, não se devia perder de vista que esta deveria ser sempre adequada $e$ completa. Para alcançar este objetivo, Carmo (1942) indicava três tipos de procedimento:

- variar a consistência;

- aumentar ou diminuir o valor calórico; e

- alterar o balanço dos princípios alimentícios.

A variação da consistência destinava-se a tornar mais fácil a mastigação e deglutição, e, finalmente, a digestão, que Carmo (1942) classificava em três grupos distintos:

I - dieta sólida (leve, composta de alimentos não-irritantes, mas de poder nutritivo elevado, capaz de reparar as perdas do período agudo das moléstias). Era o regime dos convalescentes;

II - dieta pastosa (fácil digestão, não-irritante); e

III - dieta líquida ou semilíquida (própria dos estados febris, da caquexia, das estenoses ou ulcerações do trato digestivo, dos operados da garganta etc.).

No que se refere à classificação do regime, Carmo (1942) se inspirou no Instituto de Nutrição de Buenos Aires, sob a direção do seu fundador e diretor, Pedro Escudero, que havia estudado os regimes, chegando à seguinte classificação: normal e dietético. No regime normal eram observadas as seguintes rubricas: quantidade, qualidade, harmonia e adequação. Suas variações eram:

A) com predomínio de proteínas:

- vegetal;

- animal;

- purínico; e

- apurínico.

B) com predomínio de um dos seus constituintes químicos:

- hipo ou hipergorduroso; e

- hipo ou hiper-hidrocarbonado. 
No regime dietético, eram observadas as seguintes normas: era incompleto, desarmônico e adequado, formando combinações, a saber:

A) com maior ou menor diminuição de poder calórico:

- insuficiente.

B) grande diminuição, ou supressão de um ou vários elementos constituintes:

- apurínico;

- hipoazotado;

- avitaminósico;

- hipocálcico;

- hipoférrico; e

- hipofosforado (carentes e incompletos).

C) pelo grau de desarmonia na proporção dos seus elementos constitutivos:

- hiperprotéico;

- alcalino;

- ácido;

- hiperférrico;

- hipercálcico; e

- cetógeno.

Nessa visão, as variações do poder calórico encontravam plena indicação nos casos de aumento de peso, em que se fazia mister a redução de poder calórico e também dos alimentos plásticos. No emagrecimento, o contrário se verificava. Já as variações nos constituintes da ração comportavam alterações específicas nos vários princípios, como:

PROTEÍNAS

- aumento na convalescência de moléstias febris, infectocontagiosas, nas nefrites, em que o emagrecimento intenso requeria pronta reparação; $e$

- a limitação dos protéicos, entretanto, era imperativa nas afecções cardiovasculares e cardiorrenais.

\section{GORDURAS}

- aumento, sempre que fosse necessário um elevado número de calorias;

- as taxas mais altas, como foi visto, na epilepsia; e

- restrição, nas afecções do fígado e das vias biliares, bem como na obesidade.

HidRATOS DE CARBONO

- os açúcares, os amiláceos, do mesmo modo que as gorduras, eram indicados quando se desejava aumento calórico;

- a baixa quota era recomendada em face das necessidades de restrição do metabolismo glicídico no curso do diabetes mellitus. 
PURINAS E DERIVADOS

- reduzidos ou eliminados, na gota.

SAIS MINERAIS

- restrição - afecções cardiovasculares e cardiorrenais, e nos nefríticos (cloretos);

- água, aumento nas intoxicações ou nos estados de desidratação intensa: redução, nos edematosos e infiltrados;

- cálcio e fósforo - maior consumo no raquitismo; e

- ferro - aumento nos estados anêmicos, bem como no curso da alimentação artificial do lactante.

As variações dos resíduos também constituíam medida importante no campo da dietoterapia:

- pequena quantidade ou ausência total de fibras, na febre tifóide (perigo de perfuração), nas ulcerações do trato digestivo, nas diarréias; $e$

- liberal - na constipação de ventre ou no curso de dietas restritivas em que se deseje um maior volume para aparente satisfação do doente (diabetes).

As substituições deviam ser feitas, sem causa aparente, sempre que houvesse relutância por parte do doente (idiossincrasia) ou nas manifestações alérgicas (ovos), crustáceos, certas frutas, ou, finalmente, quando aconselhado terapeuticamente (diarréia, prisão de ventre).

Recapitulando essas noções, Carmo dava a classificação dos alimentos, adotada por Escudero, para imediata aplicação à dietética, a saber:

A) Quanto à consistência

1. Alimentos líquidos:

- mate (em infusão);

- chá, café;

- caldos de carne, de verduras, de cereais e de frutas, suco de carne etc.;

- bebidas albuminosas (água albuminosa, laranjada albuminosa);

- sucos de frutas (suco de uva, extrato de uva);

- suco de vegetais (cremes, sopas de verduras);

- bebidas lácteas (chocolate com leite, café-com-leite, leite maltado); e

- bebidas à base de ovos (gemadas etc.).

2. Alimentos moles:

- frutas (purê de frutas, maçã assada, geléias, compotas etc.);

- cereais (farinhas em geral, pão com manteiga, bolachinhas etc.);

- carnes tenras, cozidas;

- queijos; 
- mingaus, purês, cremes, batatas cozidas, cará cozido, bananas assadas ou cozidas etc.;

- pastas à italiana; e

- sorvetes, doces batidos etc.

B) QUANTO AOS RESÍDUOS - OS ALIMENTOS FORAM ASSIM CLASSIFICADOS:

1. Alimentos sem resíduos sólidos:

- farinhas, cereais, sem casca;

- sopas;

- carnes - picadinhos, croquetes;

- queijos;

- sucos de todas as formas;

- pastas e substitutos (macarrão);

- doces, sem frutas e sem nozes;

- bebidas (caldos em geral);

- manteiga; e

- açúcar, sal e pimenta (moderadamente).

2. Alimentos com poucos resíduos:

- vegetais em purê (aspargo, cenoura, milho, tomate, batata etc.);

- frutas (purê de frutas em conserva, maçã assada sem casca, banana madura assada); e

- carne (de vaca, fervida, roast-beef, carneiro, fígado).

3. Alimentos com resíduos moles:

- cereais - preparações de milho, aveia e de trigo integrais etc.;

- vegetais (cozidos, não em purês, aspargos, cenouras, beringelas etc.);

- vegetais, não fervidos, tomates sem casca e sem sementes, alface etc.;

- frutas cozidas; $e$

- frutas (banana ralada, laranja, uvas sem cascas nem sementes, pêras maduras, sem casca).

4. Alimentos com muito resíduo:

- todas as frutas; três a quatro porções por dia, sendo pelo menos uma crua. Todos os vegetais, três ou mais vezes ao dia, exceto batatas. Vegetais folhosos. Cereais inteiros. Frutas: laranja, tangerina, figo, uva, pêra, maçã etc., com as suas cascas ou com os seus envoltórios de celulose (peles).

Ainda em consonância com Veloso e Siqueira, Carmo (1942) também tratou dos dilemas da arte culinária, assinalando que a primeira digestão se fazia na cozinha, devendo esta ser vista como um laboratório, em que os alimentos sofriam as transformações preparatórias, a fim de se tornar aptos a serem bem 
ingeridos e melhor aproveitados. Nessa perspectiva, o citado autor caracterizou as diversas operações culinárias pelas quais se processavam as transformações preliminares dos alimentos, com o objetivo de modificar o seu estado físico ou químico, com o que podia ser aumentada ou diminuída a sua digeribilidade e assimilação. A trituração, a redução a pó, a passagem na máquina eram atos auxiliares, tendo por fim operar a divisão dos componentes da ração.

No entanto, a associação de alimentos, como ovos com farinha, açúcar e manteiga, as batidas, as misturas de leite com cereais realizavam, por seu turno, modificações sensíveis nos pratos que não só afetavam a digestibilidade dos alimentos, mas também aumentavam-lhes a tolerância, melhorando o paladar e oferecendo uma apresentação agradável e atraente (Carmo, 1942).

Nesse aspecto, a cozinha dietética era bem diferente da cozinha comum. Esta tinha por escopo atender, de modo mais ou menos empírico, ao encargo de preparar alimentos para o indivíduo isolado, ou para coletividades, tendo em vista, em primeiro lugar, o paladar, sem a preocupação de dar à confecção dos mesmos um caráter de satisfação a necessidades nutritivas preestabelecidas (Carmo, 1942).

A cozinha dietética realizava o mesmo escopo, simplificando as operações e os pratos, restringindo ou abolindo condimentos, fazendo uso exclusivo de manteiga, óleo de oliva ou vegetal e administrando sempre quantidades precisas e previstas dos gêneros alimentícios, segundo as exigências da higiene e da nutrição (Carmo, 1942).

A primeira preocupação da cozinha dietética era conciliar os preceitos da nutrição, do bom gosto, do paladar e da apresentação, o que nem sempre era tarefa simples. Consistia nisso, seguramente, a grande vitória de Florence Nightingale, a 'mãe da dietética' quando operou milagres, alimentando soldados, durante a guerra da Criméia, variando pratos, até então monótonos, e instituindo cardápios atrativos e de boa apresentação (Carmo, 1942).

A cocção dos alimentos satisfazia a duas necessidades imediatas: de um lado, os esterilizava, graças ao calor a que eram submetidos de modo prolongado. De outro, favorecia o amolecimento dos tecidos fibrosos, tornando-os, a um tempo, mais apetecíveis e digeríveis. Assim, segundo Carmo (1942), várias transformações se operavam no curso da cocção: havia desdobramentos químicos, convertendo o tecido conjuntivo em gelatina, de mais fácil digestão. As fibras de celulose, que envolviam os grãos, sofriam tumefação, absorvendo água, e se tornavam vulneráveis ao trabalho digestivo. $\mathrm{O}$ amido dos grãos, por hidrólise, passava a dextrose, ficando muito mais apto a receber a ação dos sucos digestivos. Do mesmo modo que o amido, todos os grãos crus, insolúveis, 
solubilizavam-se pela cocção e se transmudavam em açúcar. O calor seco, por sua vez, tinha ação sobre o amido, intervindo na sua transformação em dextrina. Da mesma sorte, eram as membranas celulares dilaceradas, quebrava-se a resistência dos envoltórios isolantes das substâncias transformáveis que, assim, se expunham ao suco gástrico. Mediante o cozimento, desprendiam-se certos gases, como o anidrido carbônico, o gás sulfídrico e o aldeído fosfórico, prejudiciais ao organismo. Eram, assim, postas em liberdade substâncias extrativas, sápidas e aromáticas que emprestavam aos alimentos um. paladar agradável. Alguns alimentos, como por exemplo o bife grelhado, a farinha tostada, adquiriam, graças a essas operações, propriedades sápidas e excitantes do apetite, aumentando as qualidades dos pratos. Portanto:

Não sendo êste o lugar mais indicado para uma mais ampla explanação, poderemos, em resumo, concluir com Cesar Cardini: no curso da cocção várias operações são realizadas, sendo das mais importantes: emulsão, suspensão, variações de tensão osmótica, do grau de dispersão, e das qualidades hifrófilas dos colóides, e, finalmente, alterações da coagulação celular. (Carmo, 1942:370)

Os métodos de cozinha dietética não podiam, enfim, deixar de satisfazer certos princípios de nutrição, indispensáveis para assegurar a constância do valor nutritivo da dieta formulada. Em três princípios, Carmo (1942) resumiu esses métodos:

- reter o poder nutritivo dos alimentos;

- conservar o paladar; $e$

- manter a boa aparência dos pratos.

No entanto, a cozinha do hospital, não somente porque tinha de atender a todos os serviços com rigorosa pontualidade, como também porque nem sempre era possível fazer grandes gastos, além do seu orçamento, precisava fixar os problemas dentro das seguintes exigências técnicas:

- colocar o valor nutritivo em relação às necessidades orgânicas;

- manter o custo dos gêneros em razão do seu valor nutritivo;

- observar o menor tempo para obtenção do preparo dos alimentos; e

- conciliar com os interesses comuns o paladar, a digestibilidade e a utilidade dos gêneros empregados.

Com isso, estavam finalmente sedimentados os pontos de estudo da dietética como campo disciplinar que tinha sob sua jurisdição a dietoterapia e a cozinha dietética, daí o empenho em formar os especialistas afins.

Nesse sentido, o $2^{\circ}$ Curso de Auxiliares de Alimentação criado no Distrito Federal, em 1943, tinha características diferentes do primeiro quanto à sua organização. O curso foi organizado pela Comissão Brasileira Americana de Produção de Gêneros Alimentícios, com a colaboração do SAPS, onde se realizou. 
Nesse processo estiveram envolvidos, como integrante do convênio, por parte dos Estados Unidos, a professora Agnes June Leith, que, entre outros, ministrou aulas nesse curso, e Dante Costa, representando o Brasil, como coordenador do mesmo. O mencionado curso tinha como público prioritário os professores primários, de todos os estados da Federação, com aplicação de teste vocacional para o cumprimento do seguinte currículo: dietética; fisiologia da nutrição; ciências sociais; economia doméstica; técnica dietética; arte culinária; higiene; bacteriologia e arte culinária aplicada. ${ }^{24}$ Como se vê, embora a turma de educação do SAPS fosse integrada por esses auxiliares, não previa na sua formação a disciplina educação alimentar, o que significa dizer que ela ainda não estava definida como tal e que, no entanto, seria remetida para a formação e atuação do dietista.

Para além do âmbito do SAPS, nesse mesmo ano de 1943, era criado, pelo Decreto $n^{\circ} 14.178$, o curso de aperfeiçoamento e especialização em nutrição, do Departamento Nacional de Saúde, constituído dos seguintes tópicos:

- fisiologia da alimentação; metabolismo; bioquímica alimentar; a ração adequada;

- avaliação de estado nutritivo; doenças de carências;

- problemas econômico-sociais em alimentação; abastecimento; alimentação de massas da população; $e$

- nutrição num programa de saúde pública; problemas de alimentação peculiares ao Brasil.

Esse curso seria realizado no segundo semestre de 1944, em caráter intensivo e com a duração de três meses. Tais tópicos foram sintetizados, numa disciplina, por Josué de Castro, com três unidades de estudo:

I. estudo biológico: fisiopatologia da nutrição;

II. estudo econômico e social; e

III. dietética.

É notório que:

Ao lado deste movimento educacional contra a má nutrição, urgia a adoção de outras medidas de ordem prática, que combatendo os males já existentes, ou impedindo seu agravamento, tanto mais necessárias se faziam quando hoje, mais do que nunca, se impõe a preservação da saúde individual ou coletiva, para que não se quebre o rítmo de produção e capacidade das fôrças vitais da Nação, empenhados no esfôrço de guerra. (Universidade do Brasil, 1944:84)

${ }^{24}$ Foram professores desse $2^{\circ}$ Curso de Auxiliares de Alimentação: Dante Costa, Glauco Correia, Luiz Carlos Manzini, Agnes June Leith, Liesellote Hoeschel, Dilma Baldi, Jorge Bandeira de Mello, Edgard de Carvalho Neves e Celina de Moraes Passos (Associaçâo BRASILEIRA DE NutriçÃo, 1991). 
Isso indica a dimensão do contexto no qual os intelectuais definiam o campo disciplinar da dietética, enquanto definiam também a educação alimentar (como será visto adiante). Além disso, reflete o movimento de criação, em várias frentes, das estruturas institucionais necessárias à institucionalização da educação alimentar, bem como da prática da pesquisa no âmbito das medidas específicas que o Estado instalava, incluindo a assistência alimentar. Uma Coordenação de Mobilização Econômica foi criada pelo decreto-lei no 4.750 , de 28 de setembro de 1942, com a finalidade de coordenar e desenvolver as diversas atividades econômicas do País, tendo como coordenador o ministro João Alberto, que trabalhava em consonância com as Forças Armadas. Nesse aspecto, a Coordenação de Mobilização Econômica estava voltada para as questões emergenciais pertinentes à guerra, exercendo o controle de preços e racionalizando a produção e uso dos bens de consumo, em especial, os gêneros alimentícios. Com o início do conflito na Europa, se dava uma abrupta reorientação dos fluxos internacionais de comércio e das pautas de importação/exportação, criando, no Brasil, graves problemas de abastecimento e preços. Eleva-se, com isso, a importância dos Estados Unidos como principal mercado para os produtos brasileiros, ao tempo em que passava a ser o principal exportador para o Brasil. Quanto a isso, adquiriam expressão as missões americanas que, para aqui, se dirigiram nos anos 40 (Natal, 1982). A título de ilustração, segundo Thomas,

Em 1942, a participação americana no desenvolvimento econômico brasileiro tornou-se maior ainda, quando a administração Roosevelt enviou uma missão técnica para ajudar a planejar a mobilização do Brasil. O trabalho dessa missão, chefiada por Moris Llewellyn Cooke, foi o comêço de uma longa e estreita colaboração entre os planejadores econômicos dos dois governos. A Missão Técnica Americana contribuiu de maneira significativa para o que foi o primeiro levantamento sistemático dos recursos brasileiros, ainda que as recomendações da Missão para a assistência americana no após-guerra não fôssem seguidas. (Thomas, 1969:68)

No âmbito da Coordenação de Mobilização Econômica, foi criado, em 1942, no Distrito Federal, o Serviço Técnico da Alimentação Nacional, pelo ministro João Alberto, como principal órgão de pesquisa científica, um centro de trabalhos experimentais sobre assuntos de alimentação realizados em escala laboratorial, semi-industrial e industrial, sob a presidência de Josué de Castro. Com isso, a Coordenação visava à obtenção de elementos e dados científicos seguros, com os quais pudesse dar uma assistência técnica efetiva às fontes nacionais de produção de alimentos, aos agricultores e aos industriais. Nessa perspectiva, as pesquisas visavam aos seguintes objetivos: 
10- o conhecimento integral do valor nutritivo de certas substâncias alimentares e de outras que possam eventualmente ser usadas na alimentação humana;

$2^{2}$ - o ensaio e a standardização de métodos industriais para obter-se a desidratação e concentração das riquezas nutritivas dos alimentos;

$3^{0}-a$ obtenção através dos trabalhos em cooperação com as forças armadas, de rações supletivas e de rações de reserva para o soldado brasileiro. (Universidade do Brasil, 1944:44)

Para a consecução do segundo objetivo, por exemplo, muito contribuiu Josué de Castro, com pesquisas no campo da desidratação dos alimentos, sendo escolhido para redator de uma comissão especial de desidratação de alimentos, com o fim de apresentar ao presidente da República sugestões no sentido de ser regulamentado o assunto. Alegava Castro que, caso fosse levado a efeito tal empreendimento do Serviço Técnico da Alimentação Nacional, em breve seria criada no Brasil a indústria da desidratação em grande escala, com largas vantagens para a saúde do povo e para a economia do País (Universidade do Brasil, 1944).

Tal intento foi alcançado com a entrada dos industriais do ramo, no cenário do movimento, criando, em 31 de março de 1944, o Instituto de Tecnologia Alimentar como forma de colaborar com a Coordenação da Mobilização Econômica, no seu programa de ampliação das indústrias nacionais desse setor, naquela contingência da guerra. O Instituto tinha como finalidades:

- realizar estudos, trabalhos e pesquisas de caráter experimental no campo da ciência da alimentação e da nutrição;

- procurar resolver, cientificamente, problemas técnicos da indústria de alimentos, para cuja solução seja solicitado o concurso por parte de poderes públicos, empresas industriais ou particulares;

- dar assistência técnica à indústria de alimentos, promovendo a ampliação no campo industrial das modernas aquisições da ciência da nutrição;

- trabalhar no sentido de serem estabelecidas as especificações científicas e padrões racionais para os produtos de alimentação produzidos no Brasil;

- proporcionar, na medida de suas possibilidades, estímulo, amparo e recursos materiais a toda e qualquer iniciativa pública ou privada, que vise melhorar o padrão de alimentação do povo brasileiro;

- difundir e divulgar os conhecimentos básicos da higiene alimentar, no sentido de desenvolver uma sadia educação dos hábitos alimentares do País.

Assim, "A criação do Instituto é um índice inegável do espírito de agregação, união e solidariedade das indústrias brasileiras que mostram à sociedade o equilibrio financeiro e humanístico em que giram seus múltiplos negócios" (Universidade do Brasil, 1944:158). 
Naquele momento, os intelectuais reconheciam que, ao lado de outras cogitações, o problema do Brasil estava, antes de mais nada, no aproveitamento da mão-de-obra que tinha. Tudo dependia do povo, do número e da qualidade. Significa dizer que a questão não era encarada, evidentemente, no âmbito das relações sociais de produção, mas da qualificação orgânica da força de trabalho para que se tornassem aptos a participar do processo produtivo no contexto da industrialização e urbanização emergente, num momento de revitalização liberal. Nesse pensamento liberal, que eliminava a noção de classe social, embora falasse de classes pobres e classes ricas que se igualavam pela ignorância, vigorava a noção de adaptação e integração, cuja implicação mais evidente era uma tendência significativa de afirmar o caráter universal (pelo regional) do problema alimentar e, por extensão, das medidas compensatórias necessárias à sua solução, incluindo a educação alimentar como meio corretivo. Quanto a isso, o Serviço Técnico da Alimentação Nacional era não apenas um centro de pesquisa, como também mais uma instituição comprometida com a institucionalização da educação alimentar, mediante a promoção de campanhas educacionais para a população. Uma delas era a Campanha Nacional das Vitaminas, lançada pelo coordenador da Mobilização Econômica, ministro João Alberto. Nessa tarefa, além dos assistentes técnicos enviados a diversos centros do Distrito Federal para explicar o papel da alimentação naqueles dias, concorriam outras pessoas e instituições:

Emprestam sua colaboração a esta campanha figuras das mais representativas da cultura brasileira. Vem ela encontrando o mais decidido apôio de todos os círculos administrativos nacionais. A colaboração da imprensa, do rádio etc., na difusão dos seus conselhos sôbre alimentação e higiêne alimentar e esclarecimentos sôbre a importância das vitaminas na alimentação, tem sido das mais valiosas, e por seu intermédio, a Campanha vem preenchendo suas altas finalidades - que são as de despertar, em todo o povo brasileiro, o máximo de cuidado e interêsse para o problema alimentar, do qual dependem a saúde e a vitalidade da nossa gente. (Universidade do Brasil, 1944:80)

Com a demarcação do campo disciplinar da dietética como núcleo definidor da identidade da ciência da nutrição, vai-se revelando que a constituição da base cognitiva da educação alimentar, se dava numa intrincada rede de relações socioculturais, nas quais o grupo intelectual fundador era produtor e, ao mesmo tempo, produto. Ao afirmar as bases científicas da alimentação, delimitando fronteiras com os distintos campos de saber em vias de organização e institucionalização, no período de 1940 a 1946, o referido grupo, ao tempo em que falava ao Estado, aos patrões e ao trabalhador, se fazia ouvir também no cenário cultural global por intermédio dos variados meios culturais: imprensa, rádio etc. 
Nesse contexto, foi possível a criação do curso de nutrólogos em 1944 , como já mencionado anteriormente, enquanto se organizava também o curso de nutricionistas, no âmbito do SAPS. Era natural que, nesse processo de institucionalização, viesse à tona a discussão da terminologia desses cursos, a qual girava em torno dos termos nutricionista e dietista, ao invés da denominação de nutrólogos e nutricionistas, prevalecendo, afinal, esta última. Portanto, o primeiro curso de nutricionistas do SAPS foi criado com duração de dois anos, com as seguintes cadeiras:

1ㅇaㅇ:

- noções de anatomia e fisiologia humanas;

- noções de química;

- fisiologia da nutrição;

- dietética; e

- arte culinária e economia doméstica.

2o ano:

- bromatologia;

- estatística e educação alimentar;

- tecnologia alimentar;

- dietética;

- técnica dietética;

- arte culinária e economia doméstica; e

- serviço social. ${ }^{25}$

Isso leva à suposição de que a institucionalização da educação alimentar, ligada à estatística, tal como apresentada no currículo anterior, se deu num momento em que essa disciplina ainda não tinha bem definida a sua base cognitiva, pois o material empírico desse estudo não ventilou em nenhum momento tal conjugação e, sim, vinculava a educação alimentar à higiene e à economia doméstica, dado que era preciso ensinar o trabalhador não somente a comer, mas também a economizar. Tal indefinição fica clara quando se vê ainda que, no citado curso, a economia doméstica ficava composta com a arte culinária e não com a educação.

Nesse percurso, foi criada também, em 1944, na Secretaria Geral de Saúde e Assistência da Prefeitura do Distrito Federal, a Escola Técnica de Assistência Social, destinada à formação de visitadoras sociais, educadoras domiciliares,

${ }^{25}$ Foram professores desse primeiro curso de nutricionistas do SAPS: Agnes June Leith; Celina de Moraes Passos; Dante Costa; Edgard de Carvalho Neves; Glauco Saldanha Corrêa; Henrique Bandeira de Mello; Jorge Bandeira de Mello; José Maria Vilhena Soares; Sylvio Soares de Mendonça e Xavier Pedrosa (AssociaçĀo Brasileira de Nutrição, 1991). 
puericultoras e nutricionistas. O curso de nutricionistas dessa instituição foi organizado com a duração de dois anos preenchidos pelas seguintes cadeiras:

- $1^{\ominus}$ ano: química e tecnologia dos alimentos; anatomia e fisiologia; nutrição da criança e dietética infantil; economia dietética e arte culinária; e

- $2^{\circ}$ ano: técnica dietética; dietoterapia de adultos e crianças; noções de patologia da nutrição; arte culinária aplicada ao serviço social.

Coerentemente, a maior carga horária desse curso (305 horas) estava destinada à cadeira arte culinária e economia doméstica, compreendendo a parte prática em laboratório dietético, e as cadeiras de técnica dietética e arte culinária aplicada perfaziam um ano de curso, sendo instalado um completo laboratório dietético, com capacidade para 20 alunos. É interessante notar que a educação alimentar não fazia parte desse curso de nutricionistas, evidenciando, portanto, que na Secretaria Geral de Saúde e Assistência, a formação estava prioritariamente voltada para a dietética e a cozinha dietética. Sendo essa secretaria voltada para a saúde e assistência social local, não previa, evidentemente, programas do porte do SAPS, organizando cursos mais dirigidos para esse tipo de assistência. Nessa perspectiva, a preocupação estava muito mais na arte culinária aplicada e na economia dietética como campos de aplicação da dietética em nível domiciliar e, para isso, eram também organizados cursos de visitadoras sociais, educadoras domiciliares e puericultores, não se configurando a educação alimentar como um componente específico entre as medidas preconizadas nesse tipo de serviço social. Entre a extensa lista de professores do curso em foco, destacam-se José Messias do Carmo e Sylvio Soares de Mendonça (Associação Brasileira de Nutrição, 1991).

Em síntese, a definição do campo disciplinar da dietética e dietoterapia se situou em torno de dois pontos fundamentais para o entendimento do processo de constituição e institucionalização da ciência da nutrição/educação alimentar: o primeiro diz respeito à consolidação das leis da dietética como campo voltado para a prescrição racional e científica da dieta ou ração a todo ser humano, constituindo a identidade da ciência da nutrição; e o segundo se refere à definição da identidade do dietista (nutricionista) como traço de união entre o dietólogo (nutrólogo) e os alimentos na perspectiva da organização e produção de rações balanceadas para pessoas sãs e pessoas doentes. À parte as pequenas diferenças, muito mais de ordem técnica, entre os intelectuais, prevaleceram na definição do campo disciplinar da dietética as leis da alimentação racional, também chamadas leis de Escudero: quantidade, qualidade, harmonia e adequação. Com isso, tornava-se possivel a elaboração de modelos dietéticos regionais à luz de uma ração alimentar racional média, que tomava por base o homem brasileiro médio, fazendo uso de tabelas de recomendações de energia e nutrientes de 
procedência americana e da Sociedade das Nações, bem como tabelas brasileiras de composição química de alimentos. No âmbito da dietética, era definida também a dietoterapia como a parte da dietética que tinha por objetivo o tratamento do indivíduo por meio da dieta, e a cozinha dietética destinada ao estudo dos métodos racionais de preparo dos alimentos. Foi na interface dessa tríade que se definiu, portanto, a identidade do dietista (nutricionista) e a sua formação universitária, distinguindo-se do dietólogo (nutrólogo).

\section{Educação alimentar: uma pedagogia do mal de fome}

O processo de definição do campo disciplinar da educação alimentar evidenciou duas tendências no conjunto da produção. Na primeira, representada por Veloso, a educação alimentar estava vinculada à higiene, como já foi exposto anteriormente. Na segunda, a educação alimentar constituía um campo disciplinar específico (Siqueira, 1940; Peregrino Junior, 1941; e Carmo, 1942). No entanto, o que havia de comum entre essas tendências era a consolidação do ponto de vista de que a educação alimentar era um instrumento de correção e principal arma pedagógica no combate à fome e a subalimentação no âmbito de uma política alimentar nacional. Por esta ótica, este campo disciplinar era um meio e não um fim em si mesmo. Tendo a categoria ignorância como matriz justificadora fundamental do seu sentido, a educação alimentar se configurava como meio corretivo dos hábitos alimentares errôneos como resquícios do passado que não se ajustavam aos novos tempos. Nessa segunda tendência, a definição desse campo passava muito mais pela delimitação precisa da sua instrumentalidade. Assim, estava em questão nesse processo a definição precisa e operatória dos procedimentos de ensino, assim como dos recursos pedagógicos necessários à incorporação do padrão dietético racional e, por conseguinte, dos princípios de normatividade a ele subjacentes.

Nessa perspectiva, Siqueira (1940) definiu a educação alimentar no âmbito de uma Campanha Educacional Alimentar, esboçando, a exemplo de Veloso (1940), um plano em três níveis de ensino: para a escola primária, para as escolas secundárias, técnico-secundárias e normais e para a universidade. Transcrevendo uma frase de Roquette Pinto, "E não é por demais concluir que até mesmo aqui, no menu, o problema é, principalmente, educar" (Siqueira, 1940:145). Este, anunciava que uma campanha educacional alimentar vinha sendo empreendida, naqueles últimos anos, graças aos esforços isolados de: Hélion Póvoa, Roquette Pinto, Josué de Castro, Souza Lopes, Afrânio Peixoto, Austregésilo, Alexandre Moscoso, Castro Barreto, Dante Costa e muitos outros. Além disso:

Nós mesmos, desde 1934, nos temos dedicado ao assunto. Pela imprensa médica, pela P.R.D. 5 (Estação da nossa Prefeitura), pelo liuro, pelas palestras 
intimas no convívio da segunda enfermaria do São Francisco e pelo ensino médico, temos procurado ativamente, repetindo coisas por muitos julgadas sediças e batidas, 'educar'. E continuaremos, na medida das nossas forças, a insistir e a repetir... (Siqueira, 1940:145)

No entanto, para esse autor, tal campanha alimentar carecia de um plano sistematizado, e era quanto a isso que ele esboçava os pontos de estudo da educação alimentar para os diversos níveis de ensino:

- na escola primária deveriam ser incluídos nos programas 'mínimos' de ciências naturais pontos práticos sobre alimentação, tais como:

- frutas úteis;

- o leite, alimento máximo em todas as idades;

- os vegetais e as vitaminas;

- os bons alimentos; $e$

- o que se devia entender por uma boa e saborosa merenda etc.;

- nas escolas secundárias, técnico-secundárias e normais, deveria constar, nos programas de ciências naturais, história natural, higiene, geografia econômica e biologia, o papel da alimentação sob todos os pontos de vista: social, eugênico, higiênico, moral;

- no ensino superior, deveriam ser dadas as noções práticas indispensáveis a toda cultura universitária. No ensino médico, em particular, deveria se insistir muito sobre o assunto em várias cadeiras terapêutica, fisiologia, pediatria etc. - para que se pudesse tirar algum proveito;

- tal como já se fazia em pediatria e na Escola de Enfermeiras Anna Nery, era necessário criar escolas de dietistas e de cozinheiras; $e$

- nas fábricas, nos colégios, nas grandes coletividades (Exército, Marinha, penitenciárias, agremiações esportivas), os recursos pedagógicos adquiriam expressão por meio de vistosos cartazes, com dizeres incisivos, ensinando regras práticas de alimentação.

Entre tais recomendações, Siqueira (1940) indicava os recursos pedagógicos:

- campanha pelo rádio;

- pequenos conselhos pela imprensa;

- campanha pelo cinema - a experiência do norte-americano, com seu marinheiro Poppeye, era um magnífico exemplo. Embora o cinema daqui ainda fosse incipiente na época, segundo esse autor, deveria ensaiar alguma propaganda nesse sentido, desenvolvendo temas como: 'Nossas frutas'; 'O milho'; 'Os males de uma alimentação mal dirigida'; 'O que devemos comer'; $e$

- publicações populares, semelhantes às norte-americanas e argentinas (a exemplo da Cartilha do Trigo, elaborada pelo professor Pedro Escudero), mostrando ao povo a maneira racional de comer, publicações essas de muita utilidade, sobretudo em grandes coletividades do governo. 
Quanto a isso, Siqueira (1940) alertava que antes, porém, devia o exemplo começar de casa, segundo a qual nas campanhas educativas a pregação eugênica devia ser feita em cada lar, reiterando a recomendação de Hélion Póvoa no que diz respeito ao uso de todos os meios de vulgarização.

Coerentemente, Siqueira (1940) dedicava um capítulo do seu livro ao esboço de uma 'Cartilha alimentar dos nossos produtos animais', apresentada por ele como sugestão, na expectativa de que outros viessem a desenvolvê-la melhor futuramente. Tal empenho tinha por suposto que:

Necessita o Brasil, país essencialmente agrícola, que seus produtos principais sejam consumidos em maior escala pelos seus filhos. Para infelicidade nossa, importamos uma série imensa de substâncias animais e vegetais, que, com bôa vontade e patriotismo, poderiam ser fácilmente substituídas, com reais vantagens, pelo que possuimos. Assim, oneramos grandemente a fazenda pública comprando trigo, frutas, bacalháu e conservas, quando temos milho, banana, laranja e rebanhos imensos. (Siqueira, 1940:155)

Nessa visão, ninguém tinha tido a idéia de sugerir o aproveitamento dos maiores produtos nacionais - milho, frutas, carne, leite e café -, apresentando, nos moldes da cartilha estabelecida para o trigo, pelo professor Escudero, uma cartilha do 'que é nosso'. Conforme Siqueira (1940), este último, na Cartilha do Trigo, expunha a maneira de preparar pratos apetitosos e nutritivos e, além disso, baratos, com duas formas de trigo: o 'lavado' e o 'pilado' e acrescentava que, quando se generalizasse o costume de comer trigo, o seu país - a Argentina - economizaria muitos milhões de pesos anuais, e a agricultura acharia um novo caminho na cultura intensa do trigo.

É digno de nota que, no período de 1940 a 1946, se afirmava a expectativa nacionalista que atravessou todo o conjunto da produção em foco, em defesa do uso e aproveitamento dos nossos produtos (com destaque para a carne, leite, ovos, verduras, legumes e frutas regionais), em contraposição a uma prática perniciosa de importação de alimentos inadequados às necessidades do povo brasileiro, visto que eram de baixa qualidade. Assim, iniciando o plano da Cartilha dos Nossos Produtos Animais, Siqueira (1940) esboçava a Cartilha Alimentar do Leite. Nesta cartilha ele indicava uma série de preparações que considerava gostosas e relativamente baratas: leite com frutas (nacionais), leite com mel, leite com cacau, milho com leite, creme de leite e sorvete de leite. Além dessa, Siqueira (1940) esboçou a Cartilha dos Nossos Produtos Vegetais. Considerando a dificuldade em agrupar uma diversidade de alimentos que poderiam ser usados para a organização de cartilhas, impossibilitando a elaboração de uma cartilha completa dos produtos vegetais brasileiros, o autor elaborou apenas a Cartilha 
Dietética do Milho. Nesta, ele indicava várias receitas com milho: pão de minuto, broinhas de fubá, sopa de fubá, sonhos de fubá mimoso, pão de milho misto e bolo de fubá. Nesse aspecto, ele registrava que, com o fim de criar futuramente pratos econômicos e nacionais com os produtos daqui, ele já havia começado, há algum tempo, a estudar arte culinária. Como já exposto anteriormente, esse era um momento em que se acionavam, na iminência da guerra, as associações e instituições necessárias à instauração da ordem no mundo da produção e do consumo alimentar, tendo, como fontes de inspiração, Escudero e os norteamericanos. A esse respeito:

Não podem ser otimistas as conclusões do nosso trabalho; não chegam, porém, a cair no polo oposto, o do pessimismo. alguma cousa em pról da alimentação do brasileiro, somos obrigados a reconhecer, está sendo feita, graças à bôa vontade de uma meia dúzia de entusiastas e idealistas; (...) As tentativas no sentido de congregar todas as forças conscientes do país redundaram em lamentaveis fracassos e, por desgraça nossa, o caminho a percorrer no campo da alimentação brasileira é demasiadamente longo.(...) Enquanto, porém, nada se consegue, devem aqueles que amam verdadeiramente o Brasil, sem 'patriotadas quixotescas', persistir na rota traçada, apezar de tudo...'il ne faut jamais désesperer', pois. (Siqueira, 1940:165-166)

Nessa mesma linha, Peregrino Junior (1941) definiu a educação alimentar inspirando-se em Turner, que num artigo publicado no Journal of American Dietetic Association, afirmava: "Com inteira razão, não existir campo de conhecimento em que seja mais útil e importante a educação do povo do que o da nutrição" (Peregrino Junior, 1941:122).

O brasileiro precisava ser educado para que pudesse afirmar suas reservas físicas e morais e demonstrar suas aptidões. "Ensiná-lo a comer, para que ele tenha saúde, tenha coragem, tenha energia, e possa destarte criar sua força, e realizar sua grandeza, e traçar o seu próprio destino - eis um dos nossos deveres pedagógicos dêste momento" (Peregrino Junior, 1941:121).

Nessa visão, uma boa orientação para o Brasil seria aquela que ensinasse - povo daqui a comer de acordo com as suas necessidades biológicas, mas aproveitando sábia e economicamente os produtos peculiares de cada região do País. A exemplo de Veloso e Siqueira, Peregrino Junior (1941) reiterava que o governo brasileiro já estava conduzindo a solução do problema com lucidez e patriotismo. Partindo do princípio de que a questão tinha suas raízes mais profundas no plano econômico e no plano educacional, a política alimentar do governo tinha de se basear, como afirmava há tempos o ministro Gustavo Capanema, num complexo sistema triangular de providências: medidas de ordem econômica, de ordem pedagógica e de ordem científica. 
Inicialmente educar as classes trabalhadoras e melhorar-lhes as condições econômicas de vida - são os pontos essenciais de um programa brasileiro de política alimentar, porque isso equivale a recuperar, pela restituição da saúde, os nossos braços mais úteis, aumentando-lhes a capacidade coletiva de produção e de trabalho. (Peregrino Junior, 1941:122)

Além disso, por se achar convencido de que o problema alimentar era antes de tudo um problema de difusão de conhecimentos, de propaganda inteligente e extensa, esse autor sugeria a instituição do ensino nas escolas primárias, pois estava certo de que tal medida era oportuna e útil. Ensinando as crianças a comer, ensinaríamos indiretamente aos adultos também, porque o filho levava aos pais as boas noções que aprendia na escola. Portanto,

Ensinar os princípios elementares da ciência da alimentação às crianças e aos adultos, aos pobres e aos ricos - a todos os indivíduos úteis do Brasil - eis um belo programa de restauração física e econômica do país, e na sua execução devem colaborar, de pensamento lúcido e coração alto, todos os brasileiros de bôa vontade. (Peregrino Junior, 1940:128)

Mas qual o processo a ser adotado para a realização da educação alimentar nas escolas primárias? A caserna, a escola, o rádio, o cinema, o jornal, enfim, todos os instrumentos de educação e difusão deviam ser mobilizados nessa grande campanha nacional. Peregrino Junior (1940:128) respondia a essa questão inspirado nos norte-americanos, que, "com o seu espírito eminentemente objetivo e pragmático, têm utilizado com extraordinário êxito, na difusão de princípios salutares sôbre alimentação, os jornais infantis e o cinema, cuja figura de Poppey, campeão da propaganda do espinafre, é universalmente conhecida". No Brasil, além do rádio, do cinema e do jornal, cumpria utilizar a própria escola, ministrando o ensino de noções elementares sobre alimentação e nutrição. Nessa visão era preciso ensinar fazendo, pois o cérebro devia ser estimulado pela ação e não pelas palavras, como queriam Carlos Sá e Dewey. Exemplo disso era a Child Health Organization, dos Estados Unidos, que no seu programa de ensino de hábitos higiênicos incluíra, entre as oito regras do 'jogo da saúde', três conselhos:

- beber tanto leite quanto possível;

- comer todos os dias frutas e legumes; e

- beber no mínimo quatro copos d'água por dia. (Peregrino Junior, 1940)

Tais preceitos, uma vez repetidos diariamente, acabariam penetrando no subconsciente infantil, fixando-se definitivamente no espírito das crianças. Era certo que para o autor em foco havia outros meios de que lançavam mão os americanos, quanto a incutir, sobretudo pela emulação, bons hábitos no espírito das crianças. $O$ concurso de peso era um dos recursos adotados para o ensino dos bons hábitos. As crianças eram incentivadas a manter o peso e engordar 
regularmente, pelo que eram elogiadas em público. Das que não engordavam ou das que emagreciam, eram indagadas as regras sanitárias infringidas, os dentes cariados, a má alimentação, as vigílias etc. E então lhes eram ensinados os meios de recuperação do tempo perdido, entre outros, as 'classes de nutrição', nas quais se forneciam às crianças com déficit orgânico os alimentos sadios de que necessitavam. Outro meio importante na higiene alimentar era a merenda escolar. Quanto a isso, já havia sido divulgado aqui, pelo Departamento de Educação, modelos de merendas escolares para serem utilizadas em todo o País, de acordo com as possibilidades locais de cada região. Além disso, a inspeção médica dos alunos muito poderia contribuir, com as suas luzes e vigilância, para o bom resultado dessa campanha (Peregrino Junior, 1941).

No ensino das crianças maiores de 10 anos, já outros métodos poderiam ser utilizados, visando mais à defesa da coletividade do que o aperfeiçoamento da saúde individual. Cumpria ministrar lições especiais sobre princípios gerais de alimentação e nutrição. Em síntese, a difusão das noções essenciais sobre alimentação e nutrição podia ser feita na escola de vários modos:

- indiretamente, com a afixação de quadros murais, claros e sugestivos, sobre os sãos princípios alimentares: os alimentos mais úteis e sadios; seu teor em vitaminas, albuminas, gorduras, hidratos de carbono e sais minerais; a organização adequada dos regimes; os bons preceitos da digestão (comer devagar, mastigar bem etc.);

- ainda indiretamente, pela instituição das merendas escolares, que teriam a dupla utilidade de melhorar o estado de nutrição das crianças e incutir-lhes o hábito de comer alimentos sadios e nutrientes; $e$

- enfim, por meio de breves e claras preleções sobre a utilidade e importância de uma alimentação correta, sobre os princípios fundamentais da nutrição, sobre os perigos e os prejuízos da transgressão das boas regras da arte de bem comer.

Tais proposições penetravam a escola por intermédio do I Congresso Nacional de Saúde Escolar, realizado em 1942, conforme indica o estudo de Lima (1985) sobre saúde escolar. Para esse autor, entre outros aspectos, o avanço no conhecimento médico incorporando contribuições da psicologia, a nutrição e dietética, assim como as tentativas de intervenção tipo suplementação alimentar em creches, parques infantis e escolas, permitiu um aparato conceitual mais apurado sobre saúde escolar, o qual incluía a educação alimentar vinculada à merenda escolar. No entanto, Lima (1985) constatava que a natureza das propostas e o modo pelo qual elas eram justificadas permaneciam as mesmas dos primeiros anos deste século. A saúde escolar, em sua dimensão finalista, perseguia o fortalecimento moral, o aperfeiçoamento da raça, a formação de 
cidadãos produtivos e úteis à pátria. A eugenia continuava sendo a palavrachave. Desse modo, a educação alimentar se fazia presente entre os temas referentes à organização da saúde escolar, debatidos no mencionado congresso:

I. Organização dos Serviços de Saúde Escolar.

II. A saúde escolar nos meios urbanos e rurais. Prédio escolar; higiene do ensino; instituições peri-escolares.

III. Condições de saúde física e mental para o exercício do magistério. Exame médico-pedagógico periódico; Incapacidade física e psíquica; Razões para a aposentadoria; Leis protetoras do professor.

IV. Morbidade e mortalidade no meio escolar. Doenças para cuja evolução concorre a escola; afecções dos olhos, ouvidos, nariz, garganta e dentes; Doenças infecto-contagiosas; Incidência da tuberculose no meio escolar, Endocrinopatias.

V. A educação sanitária nas escolas. Implantação de hábitos sadios; $O$ ensino da puericultura nas escolas primárias, secundárias e profissionais; A função social da educadora sanitária; Ligação entre o lar e a escola.

VI. Higiene mental nos meios escolares.

VIII. Alimentação e nutrição dos escolares. Educação alimentar; sopa escolar; consequência da subnutrição.

IX. Bases científicas para a restauração biológica dos débeis físicos. Colônia de férias; Escolas ao ar liure; Play-ground; Jogos infantis.

X. A adaptação e a escolha das profissões. Valor do laboratório clínico e psicotécnico para a seleção nas escolas profissionais. (Lima, 1985:144-145)

Por essa mesma ótica, Carmo (1942) assinalava que se fundava o conceito da educação alimentar sobre o princípio pedagógico comum, do desenvolvimento de hábitos. Em nenhum outro assunto era tão imperativa a influência do hábito arraigado do que em matéria de alimentação, sujeita que era à ação dos costumes hereditários, dos preceitos religiosos, seitas filosóficas, crendices populares, preconceitos os mais disparatados que, desde a infância, se vinham sedimentando no subconsciente, até tomarem a forma de tabu intransponível, que se agravava pela miséria e pela ignorância.

Se era verdade que a alimentação racional, tanto do indivíduo são como a do enfermo, encontrava sérios obstáculos em certos meios, em que a falta de recursos era um óbice natural à aquisição dos alimentos, em condições satisfatórias, não era menos certo que, também nos meios abastados, eram os mesmos defeitos observados, ora pelo abuso da quantidade, ora pelo desconhecimento das regras mais elementares de higiene alimentar e de economia doméstica. O desconhecimento dos princípios que regiam a alimentação correta 
tinha contribuído tanto para os transtornos nutritivos, quanto a própria falta dos alimentos nas devidas proporções. Nesse aspecto, segundo Carmo (1942:372), já afirmava Fonssagrives: "A alimentação do rico compreende três partes: uma destinada às exigências orgânicas, outra à sensualidade e a terceira ao preparo das moléstias..." (grifo do autor).

Desse modo, a educação alimentar interessava a todos: ao pobre, quanto a ensiná-lo a dispor o seu orçamento, a adquirir os gêneros pelo menor preço, a evitar o desperdício e a saber, sobretudo, armazenar os seus mantimentos: gêneros frescos que se destinavam ao uso do dia, cereais para o gasto da semana etc. Ao rico, em primeiro lugar, a educação alimentar procuraria instruir sobre os malefícios da glutonaria, dos banquetes pantagruélicos regados etc.

Para que um plano de campanha alimentar pudesse produzir todos os seus benéficos resultados, devia convergir inicialmente sobre dois pontos: importância da alimentação e valor nutritivo dos alimentos.

Evidentemente, a educação alimentar não se limitava a ensinar esses pontos. A economia doméstica era outro ponto fundamental embutido nos argumentos dos autores. Nesse sentido, Carmo (1942) comentava que Sherman chegava a preconizar que fosse empregado um terço do orçamento de alimentação na aquisição de gêneros frescos, incluindo nessa rubrica leite e laticínios. No entanto, a melhor orientação prática havia sido dada por Miss Gillete, nos Estados Unidos, procurando orientar a economia de guerra, durante o passado conflito mundial. Essa especialista, com muita habilidade, havia estatuído a lei dos cinco quintos e que era, ao mesmo tempo, uma útil distribuição dos gêneros para a formação da dieta completa e adequada:

1 quinto - vegetais e frutas;

2 quintos - leite e laticínios;

3 quintos - carne, peixes e ovos;

4 quintos - pão e cereais; $e$

5 quintos - gorduras, açúcar, outros alimentos e extras.

Com isso, é possível sintetizar os pontos básicos do campo disciplinar da educação alimentar, os recursos pedagógicos pelos quais os conteúdos seriam transmitidos, bem como os educadores em potencial. Ao que tudo indica, tais pontos correspondiam: à importância da alimentação correta; ao valor nutritivo dos alimentos nativos; aos princípios gerais da alimentação; à organização da ração adequada (racional) e economia doméstica. Os recursos mais indicados foram: publicações (livros, folhetos, cartilhas, artigos, conferências), rádio, cinema e a imprensa. Todo o pensamento dos intelectuais se fazia em busca dessa 
especificidade da educação alimentar, o que ia contrapô-la às demais instâncias do saber. Nesse sentido, o surgimento do campo acadêmico, e, com ele, os cursos superiores de nutrição, se fazia em paralelo à elaboração desse novo código cultural. Com isso, a pesquisa passava da área dos esforços de indivíduos isolados, os precursores, para a área das instituições universitárias. A despeito desse fato, embora somente o curso de nutricionistas organizado e instituído pelo SAPS, em 1944, incluísse a educação alimentar como matéria de ensino (o mesmo não ocorria com o curso de nutrólogos), não ficava explicitamente caracterizado, no conjunto das obras, que esse especialista seria o único agente (mas agente preferencial) da transmissão desse novo código cultural. Parece que tal prerrogativa extrapolava esse limite, em direção ao âmbito da universalidade, já que a questão alimentar era universal e para a sua solução demandava o empenho de todos.

Quanto a isso, apenas Carmo (1942) afirmava que tal desafio envolvia cinco grupos de pessoas, pelas responsabilidades sociais de que estavam investidas:

- médicos - aconselhando os clientes;

- mestres - ensinando os jovens;

- os que se ocupavam com a alimentação da criança e do adulto;

- os serviços sociais, onde eram atendidas as mães, futuras mães e crianças; e

- diretores de estabelecimentos (colégios, hospitais, prisões, hotéis e quartéis).

Significa dizer que nessa visão de Carmo todos eram educadores em potencial.

De fato, no período de 1940 a 1946, a campanha universal de educação alimentar se materializava para o público, embora a fala dos intelectuais se dirigisse particularmente aos trabalhadores pobres rurais e urbanos e ao escolar, mediante a publicação dos instrumentos pedagógicos específicos, visto que era nesses segmentos sociais que o problema alimentar adquiria maior significado social.

O campo de educação alimentar, uma vez constituído como um novo código cultural, encontrava ressonância no contexto em que surgia, a partir de 1940, uma série de atividades vinculadas a uma cultura popular de massa na sociedade brasileira urbano-industrial. Segundo Ortiz (1991), nesse amplo contexto da produção e difusão cultural eram redefinidos os antigos meios (imprensa, rádio e cinema), em meio à montagem de uma indústria cultural no País. Se, durante a década de 20 , o rádio ainda estava em fase de experimentação, perfazendo apenas 19 emissoras, em 1944 passava a 106, sendo o meio de comunicação mais popular. Na visão desse autor, modificava-se o caráter do rádio, tornando-o cada vez mais comercial. Era ainda nas décadas de 40 e 50 que o cinema se tornava um bem de consumo, em particular dos filmes 
americanos, que no pós-guerra dominavam o mercado cinematográfico. Isso ocorria num momento em que se dava uma aproximação entre os Estados Unidos e o Brasil, como já visto anteriormente, fato que leva a crer que o desenvolvimento do cinema no País se fazia em estreito vínculo com as demandas políticas americanas. Em 1941 era criada a Atlântida, e em 1949, a Vera Cruz, que pretendia consolidar um pólo cinematográfico em São Paulo. Assim, o espírito capitalista e racional penetrava dessa forma a esfera cultural e organizava a sua produção nos mesmos moldes empresariais. Evidentemente, tais transformações se projetavam ao mesmo tempo no campo do esporte, na música, nas artes etc. ${ }^{26}$

Tal processo tinha como pressuposto a presença do Estado. Para Ortiz (1991), a construção da nacionalidade ainda era um projeto dos anos 30 a 50 , e não era por acaso que nesse período a questão nacional se impunha com toda a sua força. O Estado era o espaço no interior do qual se realizava a integração das partes da nação. Os intelectuais, ao se voltarem para o Estado, fosse para fortalecê-lo durante o Governo Vargas, fosse para criticá-lo, como fizeram os isebianos, o reconheciam como o espaço privilegiado por onde passava a questão cultural. Isso podia ser percebido pela relação entre o Estado Novo e os meios de comunicação de massa. Nesse aspecto, o caráter autoritário estado-novista estava na utilização de formas de ação política para civilizar as camadas populares, por meio de instrumentos dotados de grande poder de difusão, os quais tinham por função o esclarecimento, o preparo, a orientação, a exemplo do Departamento de Imprensa e Propaganda (DIP), criado em 1939, que visava interferir diretamente nos meios de grande alcance como o rádio e o cinema. Com isso, tais meios passavam de simples meio de diversão a aparelhos pedagógicos.

Por essa ótica é que o rádio e o cinema foram apontados e utilizados como recursos pedagógicos essenciais, entre outros, para promover a difusão dos pontos fundamentais da educação alimentar. Exemplo disso foi a realização do Curso Popular de Alimentação pelo Rádio, a cargo do Serviço Técnico da Alimentação Nacional (Stan), através do microfone da Rádio Ministério da Educação, PRA-2, divulgando em linguagem clara e simples conhecimentos úteis da ciência da nutrição, por meio de palestras semanais:

Esse Curso Popular de Alimentação criado com o propósito de proporcionar ensinamentos capitais não só a educadores e professores mas ao povo em geral, constou, no ano de 1943, do seguinte programa: (...) 1a lição-O problema da alimentação no Brasil. Sua importância médico-social. O alimento $2^{a}$ lição O valor das proteínas na alimentação. 3a lição - Substância energética. $4^{a}$ lição

${ }^{26}$ Para maiores detalhes sobre esse assunto, ver também SodRÉ (1981). 
- As vitaminas e seu papel. 5a lição - A vitamina $A$ em nutrição. 6a lição - As vitaminas $B$. 7a lição - A vitamina $C$ em nutrição. 8a lição - $A$ vitamina $D$ em nutrição. 9a lição - Importância dos elementos minerais na alimentação - $O$ valor do cálcio. 10 lição-O leite. Seu valor alimentar e sua importância nutritiva. 11a lição - Regras gerais de alimentação no primeiro ano de vida. $12^{a}$ lição Leite e seus derivados. 13a lição-O leite, seu valor alimentar e sua importância nutritiva. 14a lição - A alimentação e a Guerra. 15a lição - O valor alimentar do ôvo. 16a lição-Importância alimentar dos legumes e verduras. 17a lição - Valor das frutas na alimentação. 18 lição - Valor alimentar da Castanha do Pará. 19a lição-Importância alimentar do pão. 20a lição-Os cereais, as leguminosas e os feculentos na alimentação (...) (Universidade do Brasil, 1944:75)

Além disso, a título de ilustração, Carmo (1942) registrava a sua passagem no cargo de chefe de Propaganda Sanitária, da Secretaria de Saúde e Assistência Social da Prefeitura do Distrito Federal. Ele havia introduzido a representação dessa secretaria na Feira de Amostras que se realizava nessa cidade, através de um estande que passara cinco anos construindo, no qual, ao lado de outros assuntos de educação sanitária, manteve o Salão de Alimentação, nos moldes que ele havia preconizado em 1937.

O Salão de Alimentação foi uma das conquistas referidas por esse autor, pois a instrumentalização da educação alimentar adquiria expressão nas atividades em que se exibiam cartazes e documentos elucidativos sobre os preceitos da alimentação correta. Uma balança era posta à disposição do público, havendo ao lado uma enorme tabela com os equivalentes em peso e altura, ao mesmo tempo que duas figuras, de tamanho natural, fixavam as estaturas de duas crianças, uma normal e outra subnutrida. Figuras outras e cartazes apresentavam o valor comparativo dos alimentos, o seu preço médio, a sua composição e combinação na dieta. A copa e a cozinha, sem luxo, ensinavam preceitos de economia doméstica. A dispensa de modo prático, arrumada tecnicamente, indicava que gêneros deveriam ser armazenados por mais tempo. Folhetos próprios resumiam os ensinamentos contidos no Salão.

Relatou ainda Carmo (1942) que, ao lado do referido Salão, ele havia instalado o Museu da Alimentação, que fora construído com material reunido durante anos sucessivos, com a colaboração do Instituto de Educação (dr. Aramis de Matos), da Inspetoria de Alimentação (dr. Paula Rodrigues), do Laboratório Bromatológico (dr. Francisco Albuquerque) e da Escola Rivadávia Correia (prof. Bevenuta Ribeiro). O museu era composto de 60 peças aeroplásticas, dos principais alimentos, a composição das merendas, cartazes especiais munidos de mostruário de cereais, leguminosas, farináceos, açúcares etc. Segundo o autor, foi notório o interesse que o museu despertou no público que acorria aos milhares, 
tomando nota, solicitando literatura e indagando sobre tudo o que via. Em conclusão, o autor anexou na obra em foco um resumo fotográfico do Salão de Alimentação e do museu, bem como tabelas sobre o valor nutritivo dos alimentos.

Nessa perspectiva instrumentalizante da educação alimentar, Dante Costa reapareceu no cenário do período de 1940 a 1946 com o folheto Criança, as Atividades Agrícolas e a Alimentação (1945), publicado pelo Departamento Nacional da Criança, do Ministério da Educação e Saúde, na Semana da Criança. Caracterizado em apresentação feita por Olinto de Oliveira, diretor-geral do referido departamento, como um guia prático para a solução dos principais aspectos do duplo problema que se propunha a abordar, esse folheto se distinguia, evidentemente, das publicações em livro, pela pequena extensão dos temas, expostos em linguagem simples e direta, com ilustrações correspondentes, sem citações nem referências bibliográficas.

Assim, os temas abordados foram a importância da alimentação, classificação dos alimentos e seu valor nutritivo e funções no organismo, as finalidades da alimentação, os sinais da criança desnutrida e 13 normas da alimentação do escolar. Noutra parte do referido folheto, foi destacado o papel das hortas caseiras e escolares na aquisição de alimentos baratos e saudáveis: "Eis porque êste folheto possui uma parte destinada a ensinar a plantar alguns alimentos protetores e, mais do que isso, a tirar de um quintal outras utilidades, quais sejam a de transformá-lo em lugar de criação de pequenos animais" (Costa, 1945:24). Além disso, o autor alertava que todos deviam saber gastar o dinheiro destinado à alimentação, dado que:

Há sempre um progresso a fazer, em cada casa brasileira de rico ou de pobre, no tocante à melhor alimentação das crianças e dos adultos, no sentido de melhor provê-los, através de uma acertada escolha de alimentos, de atividades agrícolas de criação, e de arte culinária, que os tornam abundantes, úteis, apetecíveis e bons agentes de nutrição. (Costa, 1945:24)

Nesse aspecto, o autor foi cuidadoso em ilustrar ao leitor rural o erro pernicioso de comprar conserva em lugar de carne, ao tempo em que, nas cidades, muitos operários à hora do almoço pediam cerveja, dinheiro este que estaria sendo melhor usado numa salada ou num copo de leite. Em seguida, apresentou as técnicas do cultivo da terra, bem como da criação de pequenos animais domésticos, especificando os alimentos básicos usuais e o seu valor na alimentação. O último capítulo do folheto esteve centrado no ensino do modo de utilização dos bons alimentos, com ênfase na alimentação da criança, indicando os diversos tipos de preparações (Costa, 1945). 
Vale lembrar que, no processo de definição do campo disciplinar da dietética, os intelectuais anteriormente mencionados delinearam, também, as bases da cozinha dietética, em moldes científicos, em substituição à cozinha culinária empírica, pois de nada adiantaria à dietética estabelecer as regras científicas da ração normal racional a serem incorporadas pela educação, se a cozinha não assegurasse a constância do valor nutritivo dos elementos componentes da ração. De fato, esse era um dos campos pelos quais a educação alimentar deveria se instrumentalizar. Quanto a isso, Costa (1945), a exemplo de Siqueira, se empenhava em divulgar não apenas o valor nutritivo dos nossos alimentos e as vantagens do seu uso, mas também os procedimentos técnicos da preparação do queijo e da manteiga, a preparação de carnes, caldos e sopas, preparo de vegetais folhudos, a cocção e preparo de vegetais e frutas.

É interessante notar que, nessa linha instrumental, Siqueira (1940), retomou a iniciativa da confecção de cartilhas, como havia indicado anteriormente, publicando a Cartilha Alimentar do Homem Rural (1946), premiada no concurso de monografias promovido pelo Serviço de Informação Agrícola (SIA) do Ministério da Agricultura. Composta de 23 capítulos sem ilustrações, a publicação obedeceu às seguintes diretrizes do concurso:

- redação clara, simples, concisa e precisa; correção de linguagem;

- exatidão científica dos dados, informações, exemplos etc.;

- orientação objetiva, sem debates teóricos ou controvérsia;

- exclusão de referências ou citações alheias ao tema escolhido; e

- submissão às condições ambientais no Brasil.

Introdutoriamente, esse autor reiterava para o trabalhador rural a tese de que, para a correção dos erros alimentares brasileiros, era a educação a principal arma, o que justificava a necessidade de uma monografia destinada ao homem rural. Alertava ainda que procurava realmente evitar o excesso de terminologia científica que o homem rural estava longe de perceber e preferia, antes, expor simplesmente

o que se deve comer, o que deve ser feito, cousas a evitar (...) sem nos preocupar com o porque científico. Tal orientação espelha o 'desideratum' visado pelos organizadores do concurso: dar o indispensável A.B.C. de alimentação ao homem rural brasileiro, para que êle, conhecendo o 'quantun satis', possa produzir mais, melhore as condições de saúde de sua família. (Siqueira, 1946:7) 
No primeiro capítulo da cartilha, a relação entre saúde e alimentação exaltava as características físicas do indivíduo sadio e do doente, sendo o alimento a matéria-prima determinante desse estado orgânico:

Se V., leitor amigo, filho do campo, quiser aprender a adquirir e conservar a sua saúde e a dos seus entes queridos, espôsa, filhos, irmãos, parentes e amigos, com o auxílio de uma boa alimentação, acompanhe-nos através a leitura dêste livrinho. $E$ se seguir todos os conselhos que aqui se encontram, fique certo: V. será feliz, trabalhará melhor, produzirá mais e engrandecerá o Brasil. (Siqueira, 1946:10).

No segundo capítulo, o autor definiu o que se entendia por boa alimentação, enfocando os quatro grupos principais de alimentos:

- proteínas;

- feculentos, açucarados e gorduras;

- sais minerais, $e$

- vitaminas.

No terceiro capítulo ficou explicitado o que se devia comer - quais os alimentos que cada membro da familia devia receber diariamente. Com relação a isso, foi introduzida a frase "O homem rural não deve beber", para ilustrar algumas atitudes que o caboclo devia tomar:

Que a aguardente, a bebida maldita, com todos os seus nomes de 'caninha', 'teimosa', 'abrideira', 'parati", 'rabo de galo', 'cachaça' e outros mais, seja banida da alimentação do sertanejo, é medida que se impõe. Todo brasileiro digno desse nome estará cumprindo seu dever de cidadão se aconselhar seus amigos ou conhecidos, que têm a infelicidade de gostar de aguardente, a abandonar o vício e procurar um substituto no leite, nos sucos de frutas, no mate, no café ou no guaraná. (Siqueira, 1946:19)

É interessante assinalar que, em seguida, esse autor especificava os alimentos e suas funções e quantidades exigidas pelo organismo da criança, da gestante, do adulto e do velho, bem como os erros que deveriam ser corrigidos, incluindo o horário do uso dos alimentos, preconceitos etc. No entanto, a despeito dos desdobramentos teóricos produzidos no conjunto das obras descritas, a favor da alimentação regional, ele alertava, na monografia (cartilha) que resolveu dar normas da alimentação racional, conselhos que servissem para o homem rural de todo e qualquer rincão do País, pois seria um trabalho muito longo, complicado e sem proveito para o leitor, que queria aprender as regras de uma alimentação sadia e simples, a fixação da alimentação de acordo com as zonas em que ele vivia.

Nessa perspectiva, indicava uma série de exemplos de refeições que poderiam ser usadas no café da manhã, no almoço, no jantar, sempre acompanhadas de advertências corretivas, exemplificando erros habituais e 
concluindo com conselhos sugestivos e encorajadores: "Estamos certos de que a sua família, caro leitor, irá adotar os nossos exemplos de refeições (...) almoce de acôrdo com os consellhos que lhe foram dados agora" (Siqueira, 1946:47-51).

Quanto à economia doméstica, o autor forneceu (no capítulo 'Alimentação barata e boa') as regras e conselhos que deveria usar o "bom-senso" na seleção criteriosa dos alimentos para evitar a escolha, "a torto e a direito", dos gêneros a serem utilizados pela família. Isso podia ser feito, primeiro, escolhendo os alimentos mais úteis (numa lista indicada na cartilha) e, segundo, compondo-os o mais economicamente possível, atentando ao período de safra e entressafra que influenciava no preço. Quanto a isso, o cultivo de hortas caseiras, de pomares e a criação de animais para consumo eram medidas encorajadas e tecnicamente orientadas como recurso complementar de barateamento dos alimentos. Assim, recomendava para o trabalhador rural a orientação prática dada pela americana Miss Gillete, assinalada por Carmo (1942), reiterando que:

Uma regra prática, muito interessante que V., leitor, poderá adotar é a de dividir o dinheiro para a compra de alimentos em cinco partes e gastá-los da seguinte maneira:

1 quinto com o leite

1 quinto com frutas e vegetais

1 quinto com cereais, feijões e pão

1 quinto com carnes (ou de vaca ou de porco, ou peixe, ou ave, ou vísceras) e ovos

1 quinto com manteiga, banha, açúcar café e temperos. Quem seguir o plano acima estará gastando seu dinheiro inteligentemente. (Siqueira, 1946:68)

Contudo, Siqueira (1946) advertia que tudo isso que ele havia dito sobre alimentação não teria valor prático algum se não se desse à cozinha a atenção que ela merecia. Aliás, ele afirmava que essa era a parte da casa que ficava sempre em plano secundário, numa situação inferior e injusta, como se nada valesse na saúde da família. Era preciso desfazer esse mito, invertendo tal posição. A casa devia ser, ao contrário, uma dependência da cozinha, pois uma cozinha má expunha a família a doenças sérias, a muitos males perigosos. Assim:

Toda dona de casa que se preze deve ter conhecimentos sôbre arte culinária e meios de preservar os alimentos para que dêstes possa tirar o máximo de utilidade (...) Quantas regras elementares sôbre cozinha ignora uma dona de casa que se considera excelente cozinheira! Os métodos de preparação alimentar, usados hoje, são ainda os mesmos métodos aconselhados pelas nossas avozinhas, numa época em que eram desconhecidos muitos fatos importantes sôbre alimentação. Isso explica porque nossas donas de casa têm muitas falsas idéias sôbre preparação e cozimento de alimentos. (Siqueira, 1946:61-62) 
Nessa visão, era exaltada a inteligência da dona de casa, que passava a ter o seguinte lema em relação aos alimentos que preparava: primeiro, os alimentos deviam garantir a saúde e, segundo, deviam ter apresentação e sabor agradáveis. Portanto, as regras que uma boa dona de casa devia saber eram:

I. Lave os alimentos com todo o cuidado. Os vegetais devem perder o 'sabor' do canteiro em que cresceram.

II. Evitar descascar os legumes sempre que possível. Batatas, cenouras, inhame, cará, nabo, etc., devem ser cozidos, de preferência, com casca.

III. Cozinhe os vegetais com a menor quantidade d'água possivel e durante pouco tempo, 10 a 20 minutos.

IV. Nunca deixe os vegetais cozinhar durante longo tempo, horas a fio.

$V$. Nunca adicione bicarbonato de sódio aos vegetais que estão sendo preparados.

VI. Não jogue fora a água em que os alimentos foram preparados; aproveitea para molhos, temperos e sopas.

VII. Não pique ou esmague vegetais frescos ou frutas para deixá-los muito tempo de lado para serví-los mais tarde.

VIII. Aprenda a dar uma boa apresentação aos pratos que preparou. Um prato bem arranjado é mais gostoso que um outro mal apresentado. (Siqueira, 1946:62-63)

A referida cartilha trazia sinteticamente dez conselhos gerais sobre alimentação e higiene, no tema 'Além de se alimentar bem faça isto também':

I. Cuide dos dentes - Lavar bem a bôca e escovar os dentes são duas medidas que todo indivíduo deve adotar. Sem bons dentes é impossível uma boa mastigação dos alimentos.

II. Mastigue bem os alimentos - Os alimentos devem ser mastigados a fim de serem bem aproveitados e não forçarem o trabalho do nosso estômago e dos nossos intestinos.

III. Procure comer a horas certas - A indisciplina de horário perturba a digestão e facilita o caminho para certas doenças.

IV. Coma sem preocupações - Um grande médico brasileiro, o Dr. Hélion Póvoa escreveu certa vez: 'O momento das refeições, três pelo menos é sagrado'. Como tal, deve ser de recolhimento calmo, sem preocupações de quaisquer espécies, e todo êle - nunca menos de meia hora-dedicado exclusivamente à nobre função alimentar.

$V$. Repouse suficientemente e bem - Depois de um dia de trabalho, o repouso é mais do que necessário. Procure dormir sete a oito horas por dia, em quarto bem arejado (com janelas abertas, de preferência).

VI. Evite o uso do álcool e do tabaco - Lembre-se de que, quem se entrega ao vício maldito da 'cachaça' acaba ou na cadeia, ou no hospital, ou no hospício 
e, o que é pior, tem filhos doentes e faz a família sofrer muito. O uso do fumo prejudica bastante e tira da família um dinheiro que poderia ser empregado em outra coisa melhor.

VII. Ande calçado, sempre que puder - $O$ uso do calçado na roça é mais do que necessário, pois evita que vermes penetrem no nosso organismo e produzam o 'amarelão' ou 'opilação'. Além disso, o calçado protege o pé contra o 'bicho do pé, contra as picadas de cobra e evita cortá-lo com 'cacos' de vidro.

VIII. Além do hábito de trabalhar, 'arranje' uma distração para as horas de folga - Nas horas de folga, não querendo ficar sem fazer nada, procure distrair-se com uma coisa útil, como por exemplo, cuidar da criação, fazer uma horta ou um pomar pequeno, pescar, caçar, etc.

IX. Tome um banho diàriamente - $O$ banho diário é um hábito que todos devemos cultivar, principalmente os que vivem no interior do país. $O$ uso diário do banho evita certas doenças de pele, parasitos, piolhos e dá ao indivíduo um aspecto agradável.

$X$. Corte os cabelos e faça a barba, sempre que fôr necessário - Uma a duas vezes por Mês o cabelo deve ser cortado. Quem tem barba deve cuidar da mesma, fazendo-a, quer diariamente, quer dia sim, dia não. (Siqueira, 1946:79-80-81)

Finalmente, Siqueira (1946) passava em revista algumas noções preconceituosas espalhadas por todo o Brasil, no tema 'Não acredite', exemplificando alguns provérbios populares; entre outros, 'De manhã laranja é ouro. De tarde é prata. E de noite mata'. Ele advertia ao leitor que muitas dessas noções correntes não correspondiam à verdade e indicava que, para a desmistificação de cada uma delas, havia uma regra (verdade) científica, como por exemplo:

Não acredite. A laranja, pela manhã, à tarde ou à noite, é uma das melhores frutas, rica em vitamina indispensável para a saúde que se chama vitamina $C$. Chupe laranjas, sempre que puder (...) Zelar pela observância de bons hábitos alimentares é dever de todo bom brasileiro. Como já afirmou um grande estudioso da alimentação, o Dr. Alexandre Moscoso, 'o trabalhador bem nutrido produzirá mais para o país e fará um Brasil maior'. (Siqueira, 1946: 83-85)

Isso remete novamente à questão da polêmica relação entre a medicina científica oficial e a 'medicina popular'. Quanto a isso, Monteiro (1985) e Boltanski (1977, 1989), ao analisarem as relações entre esses dois campos, observaram que a medicina oficial, por ser uma prática dominante, é sempre auto-referente, no sentido de que, para se instituir e se exercer, se refere a seu próprio exercício e à racionalidade científica que a suporta. A medicina popular, por ser uma prática subalterna, se refere necessariamente ao modelo dominante. $\mathrm{O}$ âmbito de sua atuação se desenha, portanto, em torno desse confronto. Se, por um lado, a 'medicina popular' se envolve com os casos que a medicina oficial não consegue 
resolver, ou os casos que não são da competência médica (e nesse sentido a 'medicina popular' se coloca como sendo complementar à medicina oficial), esta, por sua vez, desconhece a existência de outra medicina que não ela própria.

A atuação da profilaxia popular se dá sempre, portanto, por referência à atuação médica hegemônica - seja contrapondo-se a ela, seja tentando complementá-la. As terapias oficiais, ao contrário, atuam sempre 'no lugar de' todas as outras práticas, isto é, desconhecendo-as ou desqualificando-as enquanto supersticiosas e ignorantes. Nesse processo, Boltanski (1989) atesta que, se é verdade que a medicina familiar moderna é antes de tudo imitativa em relação à medicina oficial, a antiga medicina popular era enraizada também na medicina científica da época, longe de constituir um corpo de conhecimentos autônomos. Os membros das classes populares, conscientes da sua estupidez, não são livres para desenvolver um discurso sobre a doença, sendo suas tentativas de explicação freqüentemente seguidas de uma constatação de ignorância ou do apelo ao único especialista autorizado a falar da doença: o médico. Os elementos culturais da medicina científica eram integrados à cultura preexistente. Na visão desse autor, tudo se passava como se o reconhecimento unânime da legitimidade do conhecimento médico oficial tivesse coagido os membros das classes populares a se despossuir de um conjunto de conhecimentos e de receitas - a medicina popular - que, sem lhes pertencer de pleno direito nem constituir uma pura criação do pensamento popular, era-lhes, no entanto, familiar o bastante para lhes permitir ter um discurso coerente, embora sumário da doença.

Nesse sentido, um traço comum da educação alimentar, como novo código cultural cientificamente constituído no âmbito da medicina, foi a desqualificação da dietética popular, igualando as classes pobres e as classe ricas pela ignorância, cujo reflexo mais imediato eram os hábitos alimentares errôneos. Assim, a matriz ignorância era usada como categoria descritiva de um processo histórico linear gerador dos hábitos alimentares regionais defeituosos, tornando-se muito mais uma matriz justificadora da educação alimentar e menos explicativa, na medida em que, além de não trabalhar com a noção de classe social - abstraindo-a em classes pobres e classes ricas -, não investigava, nos inquéritos e pesquisas realizados na época, o grau de inserção dessas classes nas diversas instâncias do sistema educacional de modo a inferir as possíveis relações com as práticas alimentares. Além disso, a universalização do problema dos hábitos errôneos apontando aspectos da inadequação alimentar entre as classes à luz dos parâmetros científicos da fisiologia desconsiderava a investigação dos códigos culturais da dietética popular apreendidas no cotidiano das classes, pois: 
fazer derivar diretamente os gostos alimentares e o tipo de consumo alimentar próprios a um grupo, das 'necessidades fisiológicas' desse grupo, é esquecer que a relação que os membros de um grupo mantêm com suas necessidades, inclusive com aquelas necessidades que correspondem às funções vitais por excelência, que são a reprodução e a nutrição, é sempre mediada pela cultura desse grupo, pois as necessidades 'naturais' só se podem exprimir e realizar uma vez retraduzidas na ordem cultural, ou seja, em conformidade com o conjunto das normas e dos valores que constituem a cultura do grupo. (Boltanski, 1989:158)

Tais ponderações se fortalecem quando se observa que a educação alimentar era concebida majoritariamente na segunda tendência em foco, no plano dos procedimentos e recursos pedagógicos. Tudo leva a supor que, dessa maneira, esse campo disciplinar ficava restrito à transmissão dos preceitos preconizados pela higiene alimentar. Configurando-se assim como campo disciplinar específico $e$ isolado das múltiplas abordagens do campo da higiene alimentar, a identidade da educação alimentar se definia em bases cognitivas estreitas e estritamente pedagógicas, e, nisso, ela diferia substancialmente da definição constituída por Veloso (1940) - designada higiene e educação alimentar -, em que a educação era parte do conjunto temático da higiene, inserida, portanto, numa visão mais ampliada das questões alimentares e nutricionais brasileiras. Finalmente, é de crucial importância assinalar que, considerando toda a duração desse processo de produção científica-cultural (1934 a 1946), ficou evidente a confluência de duas abordagens complementares na perspectiva da conexão entre o biológico e o social: uma, instrumental, (ancorada na fisiologia) voltada para as referências norte-americanas e do argentino Pedro Escudero, e outra de vocação teóricometodológica, mais vinculada à França, através da geografia de La Blache. Se, por um lado, a sociedade se tornava natural pela fisiologia, por outro, a fisiologia se tornava social através da geografia.

\section{Geografia da fome: o método revela o objeto}

O ponto de partida para o entendimento do livro de Josué de Castro (1946), Geografia da Fome, nesse estudo da gênese e constituição da educação alimentar é, primeiro, situá-lo no fechamento de um ciclo de estudos sobre alimentação e nutrição, no qual era produzido um novo paradigma científico que adquiria feições institucionais no período de 1940 a 1946 e, segundo, admitir por suposto que, nessa obra, a noção de fome na cultura brasileira surgia elaborada, cristalizada, à luz do conceito geográfico de La Blache. Significa dizer que a noção de fome era dada como acabada, e não como problema. Castro (1946), em vez de perguntar se havia fome no Brasil ou de formular a tese mal de fome e não de raça ou, ainda, em que medida ela afetava classes 
pobres e classes ricas, dava por revelada a dimensão do objeto construído através do referencial teórico da geografia. Esta obra trazia, portanto, as marcas da duração do processo de constituição da ciência da nutrição e no seu âmbito a educação alimentar enquanto acontecimento histórico.

Com isso, cristalizava-se o método geográfico de La Blache, em toda a sua extensão: localizar com precisão, delimitar e correlacionar os fenômenos naturais e culturais que se passam à superfície da terra, incluindo a nutrição humana. Quanto a isso, Castro (1946) advertia:

Não temos a pretensão de investigar a fundo numa sondagem definitiva a influência de todos os fatôres dessa categoria: raça, clima, meio biótico, etc. que constituem a base orgânica da estrutura social dos nossos grupos humanos, mas, estudando os recursos e os hábitos alimentares de várias regiōes, teremos forçosamente que levar em consideração todos êsses fatôres ecológicos que participam ativamente na interação do elemento humano e dos quadros geográficos brasileiros. Caracterizando o tipo de alimentação e os variados tipos de fome que tem sofrido a nossa gente, estamos certos que faremos refletir nessas características biológicas, com maior exatidão do que através do estudo de quaisquer outras manifestaçōes de natureza ecológica, o grau de adaptação e ajustamento dos diferentes grupos regionais de nossas populações à variadas zonas geográficas do país (...) É por isto que julgamos ser êste primeiro volume, até certo ponto, uma tentativa de interpretação biológica de certos aspectos da formação e da evolução histórico-sociais brasileiras. (Castro, 1946:28-29)

Nessa perspectiva, o estudo ecológico da fome estabelecia as correlações entre os grupos humanos e os quadros regionais que eles ocupavam, ressaltando os recursos naturais que o meio fornecia para a subsistência das populações locais, considerando os processos pelos quais essas populações se organizavam para satisfazer às suas necessidades básicas em alimentos. Castro (1946) concretizava o deslocamento do estudo da fome como fenômeno individual em seus mecanismos fisiológicos para o fenômeno da fome coletiva, revelando-a em toda a sua dimensão.

Nesse aspecto, o traço marcante da obra em foco era a delimitação dos distintos hábitos alimentares regionais como manifestações culturais dos diversos modelos de organização social e econômica, circunscritos a cinco áreas alimentares estudadas sob os aspectos naturais (paisagem natural, clima, tipos de solo, os rios, os meios de locomoção), demográficos (concentração de habitantes por $\mathrm{km}^{2}$ de superfície, movimento migratório etc.) e culturais (características da produção regional, alimentos típicos, formação e características das diferentes cozinhas regionais, composição da alimentação habitual, tipos de deficiência alimentar etc.). 
Castro (1946), ao traçar o mapa da fome caraterizando os traços biológicos e socioculturais desse fenômeno em cinco regiões brasileiras, superava os inquéritos realizados em formas parciais e chegava à descrição exaustiva dessas paisagens:

A enorme extensão territorial com seus diferentes tipos de solo e de clima, com seus múltiplos quadros paisagísticos, nos quais vêm trabalhando a séculos, grupos humanos de distintas linhagens étnicas e de diferentes tintas culturais, não poderia permitir que se constituisse em todo o território nacional um tipo uniforme de alimentação. O país está longe de constituir uma só área geográfica alimentar. As variadas categorias de recursos naturais e a predominância cultural de determinados grupos que entraram na formação de nossa raça nas diferentes zonas, tinham que condicionar forçosamente, uma diferenciação regional dos tipos de dieta. (Castro, 1946: 49)

Segundo o autor, para que uma região fosse considerada área de fome, dentro do conceito geográfico, era necessário que as deficiências alimentares, que aí se manifestavam, incidissem sobre a maioria dos indivíduos que compunham seu efetivo demográfico. Nesse sentido, das cinco áreas que formavam o mosaico alimentar brasileiro, três eram de fome: a área Amazônica, a da Mata e a do Sertão do Nordeste. Nelas viviam populações que, em sua grande maioria, exibiam permanente ou ciclicamente as marcas inconfundiveis da fome coletiva. Nas outras duas regiões, a do Centro-Oeste e a do Extremo-Sul, embora os hábitos alimentares estivessem longe de ser perfeitos, não se apresentavam contudo deficiências alimentares tão pronunciadas, a ponto de arrastarem a maioria da coletividade aos estados de fome.

Assim é que a Região Amazônica se apresentava como a mais vasta área de floresta equatorial do mundo, e uma densidade demográfica semelhante aos mais extensos desertos do planeta, com a concentração de um habitante para cada $\mathrm{km}^{2}$ de superfície, tendo como alimento básico a farinha de mandioca. Tal desproporção demográfica se configurava no maior obstáculo, segundo Castro (1946), ao uso adequado da terra e organização de um sistema econômico produtivo. Vivendo num regime de economia destrutiva, à base da caça e da pesca, da colheita de sementes silvestres, de frutas, de raízes, do látex, dos óleos e das resinas vegetais, as populações contavam com parcos recursos alimentares. Apenas em zonas limitadas e utilizando processos rudimentares se estabelecia uma cultura primitiva em que figuravam a mandioca, o milho, o arroz e o feijão. Desse modo se constituiu a alimentação do homem da Amazônia:

Alimentação pouco trabalhada e pouco atraente, apresentando até hoje em suas características, uma predominância manifesta da influência cultural indígena sôbre a das outras culturas, a portuguêsa e a negra, que também participaram de sua formação. (Castro, 1946:57) 
A farinha de mandioca, regionalmente chamada de farinha-d'água, constituía um complemento obrigatório de quase tudo o que se comia, sendo usada em forma de farofas, mingaus, de beijus e de bebidas fermentadas (cauim). O mingau característico da região Amazônica era o chibé, preparado com farinha de mandioca e rapadura, o qual se constituía em alimento predominante do trabalhador de uma extensa área amazônica, cujo preparo era de técnica indígena. Contribuíam para a alimentação os produtos da pesca, cuja variedade se fazia notar no uso do pirarucu, do peixe-boi, dos moluscos, camarões, siris, caranguejos e ostras etc., e ainda a carne e os ovos de tartarugas.

Dada a exigüidade da criação doméstica e da pecuária, pois, a floresta era um obstáculo intensivo à criação de gado, a carne, o leite e os ovos não entravam na alimentação habitual da Região Amazônica. A carne era seca e salgada e, além disso, era importada de outras regiões em pequenas quantidades. Em Belém, a mais importante cidade dessa região, o consumo diário de leite era de 20 gramas por pessoa, 30 vezes menos que o consumo médio dos Estados Unidos da América. O consumo de verduras, legumes e frutas também era irrisório, dada a baixa produção, enquanto adquiriam expressão na elaboração das comidas locais os molhos preparados com sucos de ervas e pimentas, herdados da prática indígena. Assim:

A análise biológica e química da dieta amazônica revela um regime alimentar com inúmeras deficiências nutritivas. Tem-se de logo uma impressão de sua impropriedade na sua extrema pobreza, ou mesmo ausência, de alguns dos alimentos protetores: da carne, do leite, do queijo, da manteiga, dos ovos, das verduras e das frutas. Tem-se outra imagem de sua insuficiência na sua exiguidade quantitativa. É uma alimentação parca, escassa, de uma sobriedade impressionante. O que um homem come durante um dia inteiro não daria para uma só refeição dos habitantes de outras áreas climáticas condicionadoras de hábitos diferentes. E no entanto este homem parece satisfeito de sua sorte, conseguindo com um pouco de farinha e de café e com um gole de cachaça matar a gôsto a sua fome. Mas a verdade é que se trata de populações de apetite embotado em estado de anorexia crônica. (Castro, 1946:66)

Esse autor reiterava os princípios fundamentais da dietética, assinalando que, para entender os principais defeitos da alimentação da Amazônia, precisava-se analisá-la de acordo com os modernos conhecimentos de nutrição, a saber que, para um regime ser considerado racional, devia ser suficiente, completo e harmônico:

Deve conter um total de energia correspondente às despesas do organismo, a fim de que seja considerado suficiente. Deve encerrar os diferentes elementos que o organismo necessita para seu crescimento e equilibrio funcional, para ser completo. Só será harmônico se estes diferentes elementos entrarem em sua composição, em determinadas proporções mútuas. (Castro, 1946:68) 
Quanto a isso, o regime das classes pobres de Belém era de 1.800 a 2 mil calorias diárias, quando a literatura universal recomendava 3 mil para grupos humanos em atividade de intensidade média. No entanto, Castro (1946) assinalava que tal situação não era tão drástica, considerando que o metabolismo basal do homem da Amazônia era cerca de $20 \%$ do total calórico das cifras do standard universal. Sob a ação modeladora do clima, baixavam não só as despesas fundamentais, o chamado metabolismo basal, mas também as despesas de trabalho. Com as 2 mil calorias que cada indivíduo ingeria diariamente, conseguia-se cobrir as despesas básicas e realizar-se um pouco de trabalho. Ritmo e produção eram retardados como recursos salvadores para que os nativos não morressem de fome de uma vez. A preguiça, no caso, era providencial, um meio de defesa de que a raça dispunha para sobreviver e funcionava como sinal de alarme numa caldeira que diminuía a intensidade de combustão ou quando lhe faltava combustível.

Os defeitos qualitativos eram mais graves, pois tratava-se de uma alimentação incompleta, com deficiência de elementos nutritivos das mais variadas categorias: proteínas, sais minerais e vitaminas. O déficit protéico resultava da quase ausência das fontes de proteínas animais: da carne, do leite, do queijo e dos ovos. Deficiência que se revelava pelo crescimento reduzido, pela estatura abaixo do normal que apresentavam os componentes da população amazônica. Com tais defeitos mais graves, com suas reservas umas bem, outras mal aproveitadas, a Região Amazônica fornecia subsistência às suas populações ralas e qualitativamente inferiorizadas, com suas deficiências alimentares e com suas características antropofisiológicas um tanto precárias. Por conta da subnutrição (fomes específicas em numerosos princípios essenciais), corriam, em parte, os altos coeficientes de mortalidade infantil. Em Manaus, esse coeficiente chegava à cifra de 239 por mil, quando nos Estados Unidos era de 46 por mil, na Noruega era 38, e na Nova Zelândia, 32.

Disso, decorre a evidência de que o pensamento de Castro só pode ser entendido à luz do marco teórico-metodológico construído. Qualquer proposição de leitura que se afaste dos limites do modelo explicativo adotado incorre no risco de estabelecer cortes enviesados na produção deste autor, omitindo categorias analíticas fundamentais da sua abordagem que não podem ser pressupostas, $e$ explicadas a priori apenas por uma análise externa das mudanças históricas que ocorriam no País. Nesse sentido, os ensinamentos do método geográfico forneciam a Castro as condições para a revelação do objeto, em meio às novas exigências históricas, nas quais se afirmava, como já visto neste trabalho, uma produção unitária e articulada de uma tendência majoritária da produção intelectual do 
grupo fundador da ciência da nutrição/educação alimentar em que ele era um dos protagonistas fundamentais. Desse modo, os ensinamentos do método geográfico foram esgotados no livro Geografia da Fome na medida em que, de fato, Castro (1946), com base na Região Amazônica, localizava com precisão a tragédia biológica da fome, delimitava a sua distribuição, correlacionando-a aos fenômenos naturais e culturais. A esse respeito, natureza e cultura eram instâncias inseparáveis, e nos moldes geográficos o conceito de cultura na construção do conceito de fome abrangia tão-somente as características da produção regional nas quais se estabelecia a relação entre o homem, o alimento e o meio. Era no interior da organização de um sistema econômico produtivo que se conformavam os hábitos alimentares que caracterizavam as diferentes cozinhas regionais com seus alimentos típicos e os defeitos correspondentes. É importante antecipar que, nesse conceito de cultura, a formação e as características dos hábitos alimentares estavam na dependência das condições de acesso aos alimentos, sendo este um dado significativo para reflexão, pois no marco teóricometodológico cristalizado por Castro não havia elementos para o deciframento dos códigos culturais da dietética popular elaborados na relação entre o homem, o alimento e o meio natural e cultural para que o paradigma construído se estendesse para além da cultura material.

Se isso é verdadeiro, e se a base produtiva era ameaçada pelo deserto demográfico na Amazônia, um plano de transformações econômico-sociais dessa região só poderia partir de um plano de povoamento racional e de fixação colonizadora do elemento humano à terra, pois de outro modo nunca se poderia melhorar, segundo Castro (1946), os recursos de alimentação da região. Nesse enfoque material, o problema era também desviado do plano das relações sociais de produção para o âmbito do ajustamento e integração do homem aos caprichos da natureza. "A conquista de qualquer tipo de terra pela colonização é sempre o resultado de uma luta lenta e tenaz entre o homem e os obstáculos do meio geográfico. Entre a força criadora do elemento humano e as resistências dos obstáculos naturais" (Castro, 1946:103). A fome estava presa, portanto, a quatro pontos fundamentais: produção insuficiente, dificuldades na conservação dos alimentos em condições climáticas desfavoráveis, absoluta falta de transportes e baixa capacidade aquisitiva das populações. Todos esses aspectos se ligavam uns aos outros de forma intrincada, não sendo possível resolver o problema sem atacá-lo em todos esses pontos.

Ao contrário da Amazônia, a pobreza de alimentos no Nordeste açucareiro não podia ser explicada à base de razões naturais. Para Castro (1946), os quatro séculos de ação extremada a serviço de um só objetivo - a produção da cana- 
de-açúcar - deram ao processo de transformação econômico-social dessa região o sentido de uma verdadeira experiência sociológica, servindo para demonstração viva de uma infinidade de pontos de vista fundamentais em ecologia:

É esta uma das razões por que o estudo que realizou Gilberto Freyre sôbre o Nordeste açucareiro, representa a nosso vêr, uma das aplicações mais felizes e mais fecundas que conhecemos do método ecológico ao estudo da vida econômica e social de uma região. Na paisagem nordestina a expressão geográfica é tão rica de significação e tão impregnada de história, que os seus traços componentes se destacam sempre bem ordenados, em função do elemento criador de sua vida - da cana de açúcar. (Castro, 1946:113-114)

Nessa região não havia obstáculos naturais, pois as condições regionais, tanto do solo quanto do clima, sempre foram as mais propícias ao cultivo certo e rentável de uma infinidade de produtos alimentares. Subordinando todas as outras possibilidades de cultivo aos interesses exclusivos da sua monocultura, os colonizadores destruíam também quase que inteiramente o revestimento vivo, vegetal e animal da região, subvertendo por completo o equilíbrio ecológico da paisagem, reduzindo com isso os recursos alimentares da região (Castro, 1946).

Para esse autor, os primeiros colonos portugueses traziam consigo a tradição de um bom tipo de regime alimentar, tipo de alimentação ibérica, caracterizado sobretudo por sua riqueza e variedade de vegetais - de frutas, de legumes e de verduras -, produto do cultivo intensivo, da horta e do pomar, cultivo introduzido na península pelos invasores árabes e transmitido através de séculos a portugueses e espanhóis. No entanto, esse tipo de alimentação tão equilibrado e adaptado às condições de vida tropical não foi mantido no Brasil. O primeiro obstáculo à transmissão e fixação desses hábitos alimentares sadios ao novo grupo humano em formação foi a impossibilidade de produzir nas terras quentes brasileiras o trigo, alimento básico da área alimentar mediterrânea, de clima temperado, e a sua substituição forçada pela mandioca indígena. Com isso, se procedeu ao primeiro rebaixamento no valor nutritivo do regime alimentar do reino. A farinha de mandioca era muito inferior, tanto no teor protéico, como mineral e vitamínico, à farinha de trigo com que era fabricado o pão dos ricos. Procurando ajustar-se às contingências naturais, o colonizador não só incentivou o cultivo da mandioca e de outras plantas nativas, como o aipim, o amendoim e o ananás, mas também procurou introduzir no Nordeste outras plantas que sua experiência de conquistador de terras tropicais considerava propícias ao novo quadro geográfico. Mas essa tentativa de policultura, iniciada promissoramente, foi logo substituída pela monocultura da cana.

É interessante notar que nessa viagem ao conjunto das práticas alimentares regionais do dia-a-dia da população, Castro (1946) relativizava as características 
perniciosas dos hábitos alimentares com sua correspondente arte culinária, até então rebatidas no conjunto da produção intelectual, sobretudo no período de 1940 a 1946. Segundo ele, dos processos culinários indígenas, poucos se fixaram no panorama da cozinha regional, afora o preparo da pamonha, da canjica de milho, do beiju, da farinha de mandioca e da paçoca. Outra influência favorável - mais expressiva e enobrecedora dos hábitos alimentares dessa região - foi, sem nenhuma dúvida, a do negro. A do escravo negro importado da África, em cuja área natural tinha obtido, pelo cultivo de variadas plantas, um regime alimentar dos mais saudáveis. Como povo de tradição agrícola, de tipo de sustentação, o negro reagia contra a monocultura de forma mais produtiva do que o índio. Desobedecendo às ordens do senhor, plantava às escondidas seu roçado de mandioca, de batata-doce, de feijão e de milho.

A interferência do negro no sentido de melhorar o padrão de nutrição do Nordeste se fazia sentir ainda mais do que no campo da produção em escala econômica, mediante a introdução de certas plantas africanas e do uso de certos processos culinários que se mostravam excelentes aproveitadores dos recursos alimentares da região. Era a contribuição da cozinha africana, dando lugar à cozinha baiana. Famosa não somente pela excelência dos seus temperos, pelo sabor dos seus quitutes, mas também pelos elementos que as suas criações culinárias encerravam, capazes de entravar o aparecimento de várias avitaminoses a que estariam irremediavelmente expostas as populações locais, pelo uso dos alimentos preparados exclusivamente à maneira européia (Castro, 1946).

Nessa visão, a fome não se definia tanto em virtude das deformações inerentes às características dos arranjos culinários, mas a opressão do latifundiarismo para a qual a resistência dos índios abstencionistas e dos negros rebeldes dos quilombos, e mesmo dos colonos brancos e mestiços mais pobres, desprovidos de terra, não era suficiente. Assim, segundo Castro (1946), tais segmentos subjugados pela forte pressão dos fatores de natureza econômica cederam às influências tanto naturais como culturais, e todo o complexo alimentar da região se fixou em torno da farinha de mandioca, de cultivo fácil e barato, sem grandes exigências nem de solo nem de clima, nem mesmo de mão-deobra. Complexo de alimentação muito pobre que arrastou o Nordeste à condição de uma das zonas de mais acentuada subalimentação do País, mais do que isso, zona de fome quase tão grave quanto a da região do extremo norte. Acresciamse a isso os baixos salários e o desemprego na entressafra da cana-de-açúcar.

A esse respeito, Castro (1946) assinalava que os inquéritos realizados por ele em 1932, por Antonio Freire, seis anos depois, em Recife, e por Azevedo, em Salvador, davam conta de que, no Nordeste açucareiro, do que mais se morria 
era de fome, das conseqüencias da inanição crônica e hereditária em que viviam há séculos as populações regionais. O primeiro e grave defeito evidenciado era a monotonia, a falta de variedade das substâncias alimentares que entravam na composição da dieta: farinha com feijão, charque, café e açúcar. O leite estava ausente na dieta de $80 \%$ das famílias, assim como os ovos, as verduras e frutas. O segundo traço era representado pela insuficiência calórica do regime, cujo valor energético era da ordem de 1.645 calorias; resultado semelhante (1.625) havia encontrado Azevedo, seis anos depois. Do ponto de vista qualitativo, o regime revelava excesso proporcional de hidratos de carbono, como sempre ocorria nas regiões tropicais do mundo, e deficiência de proteínas, que era de 62 gramas diários e, além disso, composta de proteína vegetal - feijão, milho e farinha de mandioca -, de baixo valor biológico. Esse era o panorama de toda a zona açucareira, com leves diferenças de coloridos locais.

Dessa alimentação precária, a primeira conseqüência orgânica era a fraca capacidade de trabalho daquela gente, que se cansava depressa ao menor esforço, que não era capaz de acompanhar o ritmo muscular do próprio trabalhador sertanejo, que sempre se sentia superior ao brejeiro, taxando-o de preguiçoso, pela pequena capacidade de trabalho que apresentava. Escapavam às carências protéicas o homem das praias ou dos mangues do litoral nordestino, em razão dos recursos oferecidos pela fauna aquática - peixes, siris, caranguejos, ostras, mariscos, camarões e sururus etc. Essa riqueza protéica e de sais minerais constituía fator de diferenciação antropológica, fazendo com que o homem da praia fosse biometricamente superior ao homem do brejo.

Vale assinalar que se até então o problema alimentar era traduzido nos termos subalimentação quantitativa, subalimentação qualitativa, subalimentação unilateral etc., nessa obra de Castro (1946) se definia o termo fome em toda a sua complexidade, nos limites do método geográfico, como expressão dos diversos gêneros de vida. Nessa perspectiva, o homem não parecia ser tão ignorante como se postulava até então, ou a ignorância não era um atributo que igualava classes pobres e classes abastadas e, menos ainda, um atributo individual. Em meio às opressões do latifúndio e da monocultura, tal homem pode melhorar seu regime local, não apenas por meio da fauna aquática, mas também lançando mão de dois produtos vegetais de alto valor nutritivo: o coco e o caju. Na cozinha nordestina, o coco entrava numa infinidade de preparações culinárias: feijão-decoco, peixe-de-coco, arroz-de-coco, vatapá, canjica, pamonha, munguzá, doce de coco, cocada e outros pratos e doces de fama universal. O coco, assegurando $25 \%$ de gordura, garantia a quota desse nutriente na dieta, enquanto o caju fornecia a vitamina C. Nisso residia a superioridade da alimentação litorânea 
sobre a da zona propriamente da mata, ou melhor, da cana. A despeito disso, sobreviviam as interdições (tabus) que se projetavam no pouco uso das frutas e verduras, estas consideradas comida de lagarta. Para Castro (1946), os tabus se constituíram como uma espécie de policiamento moral que os proprietários difundiam para defesa dos seus bens. Afirmando para os escravos e depois moradores de suas terras que certas misturas (manga com leite, por exemplo) eram perigosas à saúde, diminuíam a possibilidade de que os pobres se aventurassem a tocar nas suas frutas, egoisticamente poupadas para o seu proveito. Os tabus, assim constituídos e propagados, tornaram-se verdadeiras barreiras contra o uso das frutas e das verduras.

Se as manifestações clínicas específicas da desnutrição do Nordeste não eram aparentemente das mais alarmantes, o mesmo não se dava com as suas conseqüências indiretas: o baixo rendimento do trabalho e a elevada mortalidade infantil, a qual chegava a 457 por mil nascimentos, em Aracaju, 443, em Maceió, 352, em Natal. Outro índice ligado a essa situação alimentar era a mortalidade por tuberculose que, nas capitais do Nordeste, figurava três a seis vezes maior que no resto do País. Estavam essas cidades situadas na zona da mata: Salvador, Fortaleza e Recife, com os índices respectivos de 345, 302 e 359 por 100 mil habitantes (ano de 1939). A média brasileira era de 250 por 100 mil habitantes, e de Nova York era de 47, por 100 mil habitantes. A alta mortalidade global, e o fato de que mais de $50 \%$ dos óbitos ocorriam antes dos 30 anos de idade, vinha completar o quadro sombrio da evolução demográfica do Nordeste.

Com o estudo da Amazônia e do Nordeste açucareiro foram apresentadas as duas áreas de fome endêmicas no Brasil. No estudo do sertão nordestino, Castro (1946) ia encontrar um novo tipo de fome (o termo fome era usado no sentido generalizado), inteiramente diferente. Não mais a fome atuando de maneira permanente, condicionada pelos hábitos de vida cotidiana, mas se apresentando episodicamente em surtos epidêmicos. Surtos agudos de fome que se apresentavam com as secas, intercalando ciclicamente com os períodos de relativa abundância que caracterizavam a vida do sertanejo nas épocas de normalidade. Eram epidemias de fome global, quantitativa e qualitativa, alcançando com incrivel violência os limites extremos da desnutrição e da inanição aguda e atingindo indistintamente a todos, ricos e pobres, fazendeiros abastados e trabalhadores do eito, homens e mulheres e crianças.

Nessa extensa zona semi-árida, acossada periodicamente pelas secas, viviam cerca de seis milhões de habitantes, num regime que tinha como alimento básico o milho. Era essa zona das secas uma área alimentar do milho. Era este, associado a outros produtos regionais, numa combinação tal, que permitia que, 
fora dos quadros da seca, aquela gente mantivesse um perfeito equilibrio alimentar, num estado de nutrição bastante satisfatório, e que, nas épocas de calamidade, possuísse energia e vigor suficiente para sobreviver ao flagelo, evitando o despovoamento da região. Constituía a área do sertão do Nordeste, caso excepcional entre as diversas zonas de alimentação à base do milho, no mundo, todas elas áreas de fome, de graves deficiências alimentares como a da América Central, com suas alarmantes carências de toda categoria, como a do Sul dos Estados Unidos da América, com suas populações negras isoladas pela pelagra (Castro, 1946).

Nessa área, a coexistência de certas condições naturais e, sobretudo, o gênero de vida local, com seus hábitos tradicionais, criaram na zona um complexo alimentar no qual as graves deficiências protéicas e vitamínicas do milho eram compensadas por outros componentes habituais da dieta, talvez a mais equilibrada do País, fruto de uma saudável atuação colonizadora. Ao lado da pecuária que transformava o homem num vaqueiro, e a criação de caprinos, o sertanejo, a fim de preencher suas necessidades alimentares, também exercia a função de agricultor se dedicando ao plantio de certos gêneros de subsistência para o seu auto-abastecimento: milho, feijão, fava, mandioca, batata-doce, abóbora $e$ maxixe, plantados nos vales mais humosos, nos baixos, nos terrenos de vazante, como culturas de hortas e jardins (Castro, 1946).

Para o autor, à base de criação de gado e de agricultura de sustentação e de certos recursos escassos de pesca e caça, o sertanejo, usando métodos de preparo e de cozinha aprendidos de outro continente, adaptando até certo ponto muitos deles aos novos ingredientes da terra, criou um tipo de alimentação bem equilibrada, a qual constituía um bom exemplo de como podia um grupo humano retirar, de um meio pobre, recursos adequados às necessidades básicas de sua vida.

O milho, embora fosse o alimento básico, consumido quase que pela totalidade de seus habitantes e em quantidades relativamente altas (204 gramas diários), era apenas a base calórica da alimentação, fornecedor do grosso do total energético de sua ração, ficando o fornecimento dos outros princípios alimentares a cargo de outras substâncias. Usados sob as mais variadas formas, como angu, canjicas, cuscuz, o milho era quase sempre consumido com o leite, numa combinação feliz, na medida em que a caseína do leite cobria a deficiência de aminoácidos da zeína do milho. O leite era também consumido como manteiga e requeijão cru ou assado.

Além do leite, o sertanejo fazia uso da carne de boi, carne de carneiro, carne de bode, que constituía o grosso do consumo da região, junto com as 
buchadas (preparada com as vísceras do boi) e a carne seca ou de sol (preparo da carne ao sol por processo de desidratação que assegurava o seu armazenamento). Além desses alimentos, o sertanejo fazia uso do feijão, da farinha, da batata-doce, do inhame, da rapadura e do café. A falha principal dessa modalidade de alimentação estava no pouco uso de frutas, dada a sua reduzida produção. Segundo Castro (1946), tal alimentação era quase isenta de influência indígena e negra, podendo ser chamada de colonial pura ou de reinol, característica das influências árabes, sempre favoráveis, seivindo como mecanismo de sábia acomodação do português às contingências biológicas do sertão desértico, semelhante ao quadro geográfico natural dos árabes, aos seus desertos:

Chega-se assim à conclusão que vive o sertanejo à base de um regime que se apresenta quantitativamente suficiente para suas necessidades básicas, sem sobras, sem margem para excessos. Se isto não é o ideal, constitui contudo nas contingências especiais do meio uma circunstância mais favorável do que se fôsse êste um regime excessivo em teor energético à custa de hidrocarbonados que não se fizessem acompanhar das vitaminas necessárias à sua perfeita metabolização. (Castro, 1946:216)

No entanto, para esse autor, se na Região Amazônica a fome endêmica traduzia a luta do homem, os obstáculos principalmente demográficos, a fome epidêmica do sertão nordestino era fruto do cataclisma da seca que levava à estagnação as fontes de produção. A persistência de tal fenômeno, levando ao desaparecimento os poucos alimentos do mercado, reduzia o sertanejo ao uso das 'iguarias bárbaras', raízes, sementes e frutos silvestres de plantas incrivelmente resistentes à dissecação do meio ambiente. Faziam parte do cardápio do sertão faminto: farinha de macambira, de xique-xique, de parreira brava, de macaúba e de mucunã; palmito de carnaúba nova chamada de guandu, raízes de umbuzeiro, de pau de pedra, maniçoba, sementes de fava brava, de manjerioba, de mucunã, beijus de catolé, de gravatá e de macambira mansa. Com isso se dava a expulsão do sertanejo, que se tornava um retirante à busca de outros meios de vida. Porém, exibiam-se no sertanejo os sinais marcantes da fome quantitativa e qualitativa, cujas maiores vítimas eram as crianças: magreza extrema, lesões oculares, ósseas, bucais e motoras.

Mas para Castro (1946), as lesões físicas da fome chegavam também ao espírito. Nessa fase, desapareciam todos os outros desejos e interesse vitais, e o pensamento se concentrava ativamente em descobrir o alimento por quaisquer meios e à custa de quaisquer riscos. Era por um processo de desintegração do eu faminto que esse autor concebia o banditismo social e o misticismo que grassavam o sertão nos episódios trágicos da seca, concluindo que o seu propósito era apenas mostrar como agia, por um mecanismo biológico especial, o fenômeno 
econômico-social das fomes periódicas. Pondo em equação a influência desse fator, ao lado de muitos outros que trabalhavam em conexão nessa área, era possível obter-se uma interpretação mais justa do mistério da barbárie sertaneja, da intolerância e da valentia do homem do Nordeste, da sua sobranceria e do seu misticismo medieval.

É digno de nota que nesse modelo explicativo ia-se aprimorando uma tendência dualista em torno da existência de dois 'brasis', cuja evolução social (e alimentar) se fazia em razão de dois pólos produtivos: o moderno e o arcaico. Ao contrário das áreas anteriormente descritas, a Central e a do Sul foram consideradas por Castro (1946) como áreas de deficiências alimentares discretas e menos generalizadas. Não eram áreas de fome no sentido rigoroso do termo, mas áreas de subnutrição, de desequilíbrio e de carências parciais, restritas a determinados grupos ou classes sociais.

Abrangendo as terras do Centro-Oeste brasileiro, encontrava-se uma nova área alimentar típica, tendo como alimento básico o milho, diferenciando-se, no entanto, da área do sertão nordestino, pelas associações com que esse alimento se combinava a diferentes outras substâncias alimentares. Era a área central do milho, que abrangia as regiões montanhosas de Minas Gerais, o sertão do sul de Goiás e os pantanais de Mato Grosso. Zona em parte de clima quase subtropical, com chuvas abundantes e regulares e de temperatura abrandada em seus extremos de calor, pela altitude. Era nela que se produzia $50 \%$ do milho nacional. Além disso, possuía o maior rebanho de porco do País. Não se concluísse disso que se limitavam a esses dois produtos os recursos alimentares da região. Havia também a criação abundante de gado bovino (cerca de 20 milhões de cabeça) e o cultivo de variados produtos agrícolas, como o feijão, o café, o arroz e a cana-deaçúcar, sendo a sua paisagem regional um verdadeiro mosaico de manchas agrícolas e de pastagens. Não obstante essa elevada criação de gado, o milho, que era o alimento básico, não estava associado ao leite no regime local, mas ao feijão e à gordura de porco, num complexo nutritivo cuja expressão típica era o tutu de feijão mineiro, preparado com farinha de milho, feijão, gordura, toucinho e lombo de porco, complexo alimentar de alto valor calórico, mas qualitativamente de valor nutritivo bem inferior ao do angu ou do cuscuz de milho com leite do sertão nordestino, sobretudo por seu teor mais baixo em cálcio e em vitaminas. O leite, nesta região, passava a ser preferentemente um produto de comércio (destinado às indústrias de laticínios) e não de subsistência (Castro, 1946).

Particularmente, esse enfoque levava mais uma vez à relativização da tese da ignorância como categoria explicativa do desequilibrio alimentar e matriz justificadora da educação alimentar, quando esse autor advogava que a 
inferioridade qualitativa dos arranjos culinários do mineiro era compensada, $e$ o regime melhorava na escala biológica, em razão do consumo bem mais liberal que se fazia nessa zona de vegetais verdes, sobretudo das couves. A couve mineira era componente habitual da cozinha regional, servindo de boa fonte de sais e de vitaminas. Outras hortaliças e frutas eram de uso mais amplo do que nas outras áreas até agora analisadas, principalmente a laranja, o mamão, a banana e o abacate. Produtos de cana, como o caldo, o melado, a rapadura, eram largamente consumidos em certas áreas onde proliferavam os pequenos engenhos de açúcar.

Assim, a análise química desse regime permitia verificar que não havia déficit calóricos; ao contrário, devia haver, até certo ponto, excesso quantitativo, por conta do elevado consumo do milho e da gordura de porco, o que resultava na maior incidência nessa zona de obesidade do diabete, "e na formação do tipo biológico dos mineiros lentos e pesados, conservadores e pachorrentos" (Castro, 1946:280). Entretanto, os déficits qualitativos não eram intensos a ponto de se expressarem em carências declaradas, manifestas clinicamente, mas apenas em formas discretas. Havia apenas uma carência que, por exceção, se estampava nessa área - era a carência em iodo. A pobreza desse metal nas terras montanhosas mineiras, no solo, na água e nos vegetais ali produzidos era responsável pela enorme incidência do cretinismo endêmico nessa região, cretinismo que se manifestava numa rica gradação de formas clínicas, bociosas ou não.

As conseqüências dessa endemia carencial eram muito graves sobre o psiquismo daquela gente. As alterações orgânicas se manifestavam pelas deficiências de crescimento, pelas deformações locais e gerais, pelas alterações de todo o metabolismo que se regia sob o influxo da tireóide. Sobre o psiquismo, o bócio endêmico atuava profundamente, constituindo os casos de cretinismo, de imbecilidade, de idiotice hipotiróidicas. Essa carência grassava no Brasil, desde os tempos coloniais, alcançando maior grau de incidência nos estados de Minas Gerais, São Paulo, Rio de Janeiro, Paraná, Goiás e Mato Grosso (Castro, 1946).

Nesse mapeamento, a área do sul era representada geograficamente pelo Distrito Federal e pelos estados do Rio, São Paulo, Paraná, Santa Catarina e Rio Grande do Sul, sendo caracterizada por maior variedade de elementos componentes do seu regime alimentar e pelo consumo mais alto das verduras e das frutas. Sendo essa zona a mais rica do País, de maior desenvolvimento, tanto agrícola como industrial, compreendendo $80 \%$ da capacidade econômica de toda a nação, não era de estranhar que dispusesse de elementos para tornar mais elevado o seu padrão alimentar. O primeiro fator dessa melhoria estava na 
sua base econômica mais sólida, visto que a capacidade de produção per capita, em certos pontos dessa área, como no Distrito Federal e em São Paulo, era dez vezes mais alta do que a dos estados do Norte. Outro fator decisivo dessa superioridade regional era a própria produção mais abundante, dado que a área do Sul, contendo $31 \%$ da população nacional, concentrava $40 \%$ da produção de alimentos de todo o País. Tanto as condições do seu solo e de seu clima como a influência favorável das recentes levas de imigrantes que lá se iam fixando do século passado até aqueles dias, tudo isso tinha trabalhado num sentido de diversificar os recursos alimentares da região e de utilizá-los de maneira mais racional. Assim, encontrávamos desde a alimentação predominantemente vegetariana, caracterizada pelo largo uso do trigo, sob a forma de macarrão ravioli e spaguetti, como na área paulista, trazendo a influência do tipo da alimentação italiana, até o tipo oposto de alimentação, de predominância carnívora, como no Rio Grande do Sul, caracterizada pelo complexo alimentar do churrasco e do mate-chimarrão. As colônias japonesas localizadas nas proximidades dos centros urbanos, como em torno da capital de São Paulo, tendo dado grande incremento às culturas hortícolas, tornaram mais abundante o consumo das verduras naquela área. Nas áreas de maior influência germânica encontrar-se-ia um consumo mais freqüente de aveia, centeio, lentilhas, hortaliças e frutas, assim como da carne, sobretudo a de porco, em suas inúmeras variedades de salsichas, bacon, presunto doméstico, carne de fumeiro, comidos com pão preto, chucrute e cerveja.

Não se deve concluir dessa lista de substâncias alimentares, produtos da ação conjunta de fatores naturais e culturais favoráveis, que a alimentação naquela área fosse perfeita, isenta de deficiências e de desequilírios. Embora fosse superior às outras áreas brasileiras, estava longe daquele tipo de alimentação dos habitantes da Califórnia e da Nova Zelândia, por exemplo.

Os inquéritos haviam mostrado que as dietas locais eram, sob diferentes aspectos, incompletas e impróprias. Apesar da maior tendência de os paulistas consumirem trigo, frutas e verduras, sofriam contudo de carência de certos princípios nutritivos, conforme atestavam os inquéritos de hábitos alimentares e de nutrição levados a efeito por Almeida Júnior, Paula Souza e outros. Se em Santa Catarina a alimentação popular se mostrava na indagação de Arruda Câmara de um modo geral suficiente e equilibrada, no Rio Grande do Sul encontrou Cleto Seabra Veloso, em 1942, um regime insuficiente e carenciado em vários elementos nutritivos, o que explicava, em parte, a elevada incidência de tuberculose naquela região. Chegava-se, então, à conclusão de que o Sul era uma zona de subnutrição crônica, onde as populações, sem apresentarem, em escala social, carências e avitaminoses 
clinicamente alarmantes, estavam, no entanto, longe de gozarem dos benefícios de um metabolismo perfeitamente equilibrado.

Portanto, o método geográfico revelava a dimensão do objeto quando o referido autor traçava finalmente o mapa alimentar brasileiro abrangendo cinco diferentes áreas alimentares (autônomas), cada uma delas dispondo de recursos típicos, com sua dieta habitual apoiada em determinados produtos regionais e com seus efetivos humanos, refletindo, em muitas de suas características, tanto somáticas como psíquicas, tanto biológicas como culturais, a influência marcante dos seus tipos de dieta: "o Brasil é um dos países de fome no mundo atual. Tanto em seus quadros regionais, como em seu conjunto unitário, sofre o Brasil as duras conseqüências dessa condição biológica aviltante de sua raça e de sua organização social" (Castro, 1946:290-291).

Era no estudo do conjunto brasileiro que Castro (1946) fazia uma síntese de sua abordagem. A fome no Brasil era conseqüência, antes de tudo, do seu passado histórico, com os grupos humanos sempre em luta e quase nunca em harmonia com os quadros naturais. Com isso ele esgotava as possibilidades explicativas desse fenômeno no âmbito do método geográfico, por meio do qual projetava o embate entre o arcaico e o moderno, o velho e o novo:

O Brasil como país de tipo semi-colonial, com sua agricultura semi-feudal à base de processos agrícolas arcaicos e de manifesta tendência à monocultura latifundiária apresenta coeficiente de produção alimentar muito abaixo das necessidades biológicas de suas populações (...) Em última análise, esta situação de desajustamento econômico-social foi consequência da inaptidão do Estado Político para servir de poder equilibrante entre os interêsses privados e o interêsse coletivo. Incapacidade do poder politico para dirigir em moldes sensatos, aventura da colonização e a organização social da nacionalidade, a princípio por sua tenuidade e fraqueza potencial diante da fortaleza e independência dos senhores de terras, 'manda-chuvas' em seus domínios de porteiras fechadas indiferentes aos regulamentos e à ordens do Govêrno que viessem contrariar seus interêsses; e ùltimamente, num contrastante exagero noutro sentido, no excesso centralizante do poder, tirando das unidades regionais tôdas as receitas e todos os direitos para depô-los nos braços, um tanto curtos, em espalhar benefícios, do poder central. (Castro, 1946:292-293-298)

Nesse registro de Castro ficava evidente que o Estado falhava por incompetência para operar a colonização e a organização da nacionalidade tão propaladas pelo movimento nacionalista, não conseguindo pôr nos seus devidos lugares as forças agrárias conservadoras, descumprindo o seu papel de mediador e representante do interesse geral. No entanto, a principal conseqüência do excesso de centralização era o abandono do campo em prol de uma urbanização que, 
não encontrando no campo uma civilização à altura dos novos tempos, vinha acentuar de maneira alarmante a deficiência alimentar. Não se conclua disso que Castro era contrário à industrialização. Na sua visão, a urbanização não era um mal em si mesmo e, sim, representava uma fase de transição entre a economia agrária pura e a agroindustrial. Como esse autor rejeitava a tese neomalthusiana do aumento desproporcional da população em relação à produção de alimentos como fator determinante da fome, considerava que a subnutrição crônica que se acentuava naqueles anos se dava pelo crescimento normal da população sem a equivalente expansão da produção, $e$ isso era decorrência de uma inversão de prioridades graves da política econômica do governo, que estabelecia privilégios desmedidos à indústria nacional, deixando ao abandono as atividades agrícolas. As estatísticas comprovavam que enquanto havia aumento na produção de alimentos naqueles últimos 15 anos, da ordem de apenas $25 \%$, havia aumento na produção de matérias-primas para a indústria, de cerca de $400 \%$. Além disso, contribuía para a degradação da alimentação no País a proliferação de uma indústria arcaica de alimentos, sem assistência nem recursos técnicos adequados, bem como controle científico sistemático de sua produção, lançando no mercado produtos de qualidade inferior e valor nutritivo duvidoso.

Era, portanto, severamente ameaçado no período de 1940 a 1946 o esforço de construção de uma nova civilização, mediante a intervenção planejada do Estado, tendo como idéia central a unidade nacional na qual seria construído o homem brasileiro símbolo da robustez e eficiência. É por essa ótica que se pode entender o significado da Geografia da Fome como marco de amadurecimento não apenas do percurso intelectual de Castro, mas também de um conjunto de estudos pioneiros de um grupo fundador da ciência da nutrição/educação alimentar no Brasil, que chegava no ano de 1946 à consolidação de uma tendência explicativa que inaugurava um novo paradigma à luz do método geográfico. Nesse sentido, a Geografia da Fome evidentemente não revelava rupturas com a produção inicial do grupo, mas reorientava, em certa medida, o enfoque até então travado em torno das relações entre fome, eugenia e evolução social, abrindo novas perspectivas que apontavam para o começo de um novo tempo.

Castro (1946) cristalizava a superação do enfoque centrado apenas na educação do trabalhador, no fornecimento de refeições e na distribuição de alimentos que havia sido assimilado nas estratégias populistas do SAPS (1940), cujo destaque central era a correção dos hábitos alimentares dos operários, como já visto anteriormente. Ele circunscrevia a educação alimentar à situação global da alimentação do povo, na qual figurava, entre outros aspectos: 
O absoluto desconhecimento, por parte do povo, dos fundamentos da higiene alimentar, do valor nutritivo dos gêneros alimentícios, dos processos adequados à sua conveniente produção, conservação e preparação, tornam o seu rendimento útil sempre precário (...) os maus hábitos alimentares decorrentes da rotina deformadora do sadio instinto nutritivo, os tabus e as interdições alimentares de toda ordem e, finalmente, o limitado poder aquisitivo da massa para o qual o custo dos alimentos protetores os torna inacessíveis aos seus orçamentos domésticos (...) fazem do tipo de alimentação no Brasil, um dos mais precários do mundo. (Castro, 1946:296-297)

Assim, viu-se anteriormente que a criação da Sociedade Brasileira de Alimentação, do Serviço Técnico da Alimentação Nacional, do Instituto de Tecnologia Alimentar e a perspectiva da criação do Instituto de Nutrição eram iniciativas que, embora voltadas também para a educação alimentar, já buscavam a ampliação do tratamento da questão alimentar no País. Além disso, os Arquivos Brasileiros de Nutrição, lançados em 1944, se configuravam no instrumento de difusão do grupo intelectual não só dos avanços da ciência da nutrição, mas também das metas alcançadas nesses campos institucionais. Portanto, Castro (1946) circunscrevia definitivamente a fome no campo do debate sobre a organização do Estado e da política econômica. O encontro da fisiologia com a geografia possibilitava visualizar o homem brasileiro não como entidade, mas o homem concreto que habitava as diversas paisagens brasileiras em constante luta com os obstáculos do meio geográfico.

Evidentemente, o autor aderia àqueles que acreditavam na viabilidade da nação e se mobilizavam em torno das questões prementes da época. Segundo Pecaut (1990) e Mota (1994), em 1945, o debate intelectual girava em torno da questão da democratização, no qual emergiam novos atores e com eles uma plataforma da nova geração, em que perpassavam os temas da existência nacional, renda nacional, a cultura da nação e os problemas nacionais, em torno dos quais se preservava a utopia da União Nacional. A democracia real que muitos invocavam era aquela na qual o povo se identificava com a nação: o tema democrático estava subordinado ao tema nacional. Esse nacionalismo não tinha relação com o do período de 25-40. Era um movimento de democratização que não previa o desmonte das estruturas autoritárias, pois, como diz Pecaut (1990), a maioria continuaria a defender a democracia, mas, freqüentemente, sem questionar as instituições, os procedimentos e as formas de legitimação que lhe são inerentes:

Ninguém mais duvidava da existência de uma nação brasileira, e não era mais preciso buscar seus sinais no 'caráter' ou no 'temperamento' da população, nem apelar ao Estado para forjar a sociedade. A nação estava ali constituida em 
torno de seus interesses econômicos, de sua cultura e de sua vontade política. Ela se experimenta a si mesma, afirmando-se dia a dia contra as nações dominantes. O sentimento de identidade é substituido pelo de confronto; o advento do povo como sujeito político liga-se à sua mobilização a serviço da soberania nacional. (Pecaut, 1990:99)

Quanto a isso, o I Congresso Brasileiro de Escritores, realizado em 1945, representava um momento significativo na história da cultura no Brasil, fornecendo formas de pensamento ideológicas em relação a um contexto específico, no final do Estado Novo. E, sobretudo, para avaliar os significados emprestados à atividade intelectual e à própria noção de cultura brasileira. Cultura e política, naquele contexto, se entrecruzavam; enriquecia-se a noção de cultura, ampliando o sentido de engajamento, adensando-se e oferecendo novos conteúdos à temática da militância política do intelectual. A partir da crise política e da necessidade de se buscar novas fórmulas, os congressistas repensavam o processo cultural no País, condensando suas posições num manifesto-proposta, lançado em 26 de janeiro de 1945, que continha os pontos de uma política democrática de educação e cultura (Mota, 1994).

A título de ilustração, nesse manifesto transcrito pelo citado autor estavam, entre outros pontos ligados à educação e à cultura, as posições da comissão de imprensa que atacavam diretamente o Departamento de Informação e Propaganda (DIP), condenando toda e qualquer espécie de censura, por ser incompativel com a livre manifestação do pensamento por intermédio do jornal, do rádio, do teatro, do cinema e do livro, solicitando ao governo federal a suspensão das medidas restritivas adotadas por esse departamento, tanto quanto ao registro das revistas literárias como ao das demais revistas, periódicos e jornais, limitando-se o registro das publicações às informações estatísticas. Como visto anteriormente, o regime Vargas penetrava, por intermédio do DIP e de outras organizações, em todas as atividades culturais, cinema, teatro, rádio, literatura etc. em nome da defesa da cultura nacional.

Para Mota (1994), duas teses apresentadas e aprovadas no I Congresso Brasileiro de Escritores pareciam simbolizar o encerramento de uma etapa cultural e a abertura de outra. A contemporaneidade de dois processos significativos intimamente articulados, como o fim da Segunda Guerra Mundial e a suspensão do Estado Novo, repercutiu na intelectualidade de maneira a criar a sensação de 'fim de ciclo'. Este, estava simbolizado em O Apoliticismo dos Intelectuais, do pernambucano Osório Borba, e em Democracia e Planificação, de Pontes de Miranda. No trabalho de Borba era criticado o conformismo dos intelectuais, apontando o que, na prática, representava a acomodação passiva a todas as situações criadas pelos inimigos da inteligência. Já no trabalho de Miranda 
encontrava-se o prenúncio de uma etapa nova na história do Brasil, a do desenvolvimento planejado da economia liberal, qualificado, naquele momento, como "progressista". Assim:

O desenvolvimento 'progressista' da economia liberal, o desenvolvimento planejado começava a se anunciar nos horizontes da intelectualidade mais aberta às novas tendências do final da guerra. A reconstrução material da Europa, a articulação da economia japonesa, os planos quinquenais na União Soviética, as marcas do New Deal indicavam nesta área 'periférica' - para utilizar a expressão cara aos nacionalistas - a direção a seguir, rumo ao desenvolvimento planejado. (...) largos setores da intelectualidade brasileira (...) passaram a empenhar-se na fabricação de modelos de desenvolvimento nacional, num processo que terá sua plena florescência na década seguinte (...) Da 'consciência amena do atraso' 'da ideologia de país novo', que vigorava no período anterior, passava-se à ideologia de 'país em vias de desenvolvimento'. Como regra geral, e da qual haverá notórias exceções, de burocrata do Estado Novo, o intelectual típico (por assim dizer) passará a ideólogo do desenvolvimentismo. (Mota, 1994:152-153) ${ }^{27}$

Era na emergência desse novo contexto cultural e político, no qual surgiam as primeiras idéias desenvolvimentistas, que Castro (1946) preconizava a estruturação de um plano sistematizado de política alimentar, tomando em consideração os diferentes aspectos biológicos, econômicos e sociais que interferiam no mecanismo do complexo problema alimentar: incremento da produção agrícola por meio de reforma agrária (combate ao latifundiarismo improdutivo, combate à monocultura, aproveitamento racional de todas as terras cultiváveis, intensificação do cultivo de alimentos sob a forma de policultura, mecanização intensiva da lavoura, controle e orientação da produção total com vistas à satisfação das necessidades alimentares mínimas do povo, financiamento bancário à agricultura, amparo e incentivo ao cooperativismo); intensificação dos estudos técnicos de bromatologia e de nutrologia; e, finalmente:

planejamento de uma campanha de âmbito nacional para formação de bons hábitos alimentares, a qual envolva, não só o conhecimento dos princípios básicos de higiene como o amor à terra, os rudimentos de economia agrícola e doméstica, os fundamentos da luta técnica contra a erosão e contra os estragos de tôdas as categorias dos recursos alimentares. Através dessa campanha poderá ser progressivamente captada a colaboração ativa da massa, no sentido de defender os recursos alimentares do país contra os assaltos degradadores de certos agentes naturais e das explorações econômicas intempestivas, de nocivos interêsses

${ }^{27}$ Coincidentemente, ao alvorecer das idéias desenvolvimentistas, era finalmente concedida autonomia didática, administrativa, financeira e disciplinar à Universidade do Brasil, em 1945, na qual Josué de Castro era professor catedrático (BRASIL. LeIS E DECRETOS, 1946). 
econômicos, nem sempre solidários com os interêsses biológicos do povo. $O$ preparo psicológico da massa na realização de qualquer plano realmente efetivo, $e$, nesse campo, essencial, desde que êste preparo constitui, como acentúa Mattos Pimenta, 'o elemento fundamental criador de tôdas as realizações'. (Castro, 1946:304-305)

Ora, é evidente que tal postulado descartava, de fato, a educação alimentar como um campo disciplinar específico, centralizado nos recursos pedagógicos para a transmissão dos conhecimentos básicos da higiene alimentar, mas vinculava a educação à higiene alimentar, à qual congregava toda a amplitude dos aspectos estudados sob a orientação do método geográfico que permitia, em última instância, tratar a fome numa perspectiva ecológica. Para alcançar tal objetivo, Castro (1946) preconizava a criação de um órgão técnicoadministrativo que unificasse o problema, desenvolvendo medidas articuladas num plano de longo alcance, incluindo as de caráter urgente por ele enunciadas.

O término do conflito gerado pela guerra acarretou o desaparecimento do Serviço Técnico da Alimentação Nacional, sobrevivendo o Instituto de Tecnologia Alimentar. Uma vez concedida a autonomia à Universidade do Brasil, os responsáveis pelo Instituto resolveram doá-lo à Universidade, com instalações e patrimônio em dinheiro, com a finalidade de que, sobre essa base, fosse criado o Instituto de Nutrição. Aceitando a doação e o compromisso, o reitor da Universidade, professor Inácio de Azevedo, as providências necessárias, junto aos poderes públicos, para que fossem determinados os atos legais que efetivassem a idéia, tendo finalmente sido baixado o decreto $\mathrm{n}^{\circ} 8.684$, de 16 de janeiro de 1946, incorporando o Instituto de Tecnologia Alimentar à Universidade do Brasil (atualmente Universidade Federal do Rio de Janeiro), para o fim de constituir o Instituto de Nutrição (Universidade do Brasil, 1946). Convidado para organizar e dirigir a nova instituição, Josué de Castro apresentou ao reitor o plano organizacional, aprovado por unanimidade no Conselho Universitário, incluindo entre suas finalidades a educação alimentar, como segue:

a) realizar investigações de natureza biológica e de natureza econômica-social acêrca do problema da alimentação humana no nosso meio;

b) realizar pesquisas e ensaios tecnológicos que conduzam à melhoria das condições de produção dos alimentos usuais;

c) proceder a estudos que venham a permitir o conhecimento preciso das afecções patológicas resultantes das falhas, das deficiências e dos desequilibrios da alimentação e da nutrição dos brasileiros;

d) aplicar os conhecimentos da ciência da nutrição ao tratamento dos doentes e desenvolvimento entre nós das bases científicas da dietética e da dietoterapia; 
e) formar técnicos especializados nos problemas da alimentação e nutrição; f) difundir os conhecimentos de higiene alimentar através dos diferentes recursos educacionais. (Universidade do Brasil, 1946:72)

Para isso, o Instituto Nacional de Nutrição compreendia as seguintes seções:

I - Secção de Pesquisas Biológicas;

II - Secção de Pesquisas Sociais;

III - Seç̧ão de Educação Alimentar;

IV - Secção de Patologia da Nutrição.

(...) Art. $5^{\circ}$ - Compete à Secção de Educação Alimentar organizar cursos a serem ministrados no Instituto de Nutrição e divulgar pelos diferentes meios os conhecimentos da ciência da Nutrição. (Universidade do Brasil, 1946:72-73)

No que se refere aos cursos previstos a serem organizados pela Seção de Educação Alimentar, o parágrafo único do artigo 5 previa o seguinte: "a) curso de divulgação entre o povo dos elementos fundamentais da higiene alimentar; b) cursos regulares para formação de técnicos especializados: médicos nutrólogos e nutricionistas ou dietistas; c) cursos de extensão universitário sobre matérias avulsas que façam parte dos conhecimentos da ciência da nutrição" (Universidade do Brasil, 1946:73)

Parece haver um descompasso entre as finalidades da educação alimentar desse Instituto, na medida em que se limitava à difusão dos conhecimentos da higiene alimentar (como se vê anteriormente na alínea 'f', que trata desse assunto) e o que Castro preconizava na obra Geografia da Fome, em que afirmava que uma campanha nacional de formação de bons hábitos alimentares não passava apenas pela difusão dos conhecimentos de higiene, como já discutido anteriormente, o que mostra a relativa independência entre a trajetória científica e a trajetória institucional.

Em 1948 foi criado o primeiro curso de dietistas no âmbito do referido Instituto, com duração de dois anos, assim distribuídos:

- 1a ano - anatomia e fisiologia humanas; dietética; química; técnica dietética e arte culinária; bromatologia; e

- $2^{\circ}$ ano - dietoterapia; patologia da nutrição; puericultura e dietética infantil; técnica dietética e arte culinária; higiene e educação alimentar; economia alimentar; organização e administração de serviços de alimentação (estágios).

O Instituto de Nutrição tinha à frente o diretor-geral Josué de Castro, além de Rubens de Siqueira como diretor dos cursos (Associação Brasileira de Nutrição, 1991). 
Com isso parece ficar claro que a educação alimentar, embora ganhasse uma seção própria na estrutura do Instituto Nacional de Nutrição da Universidade do Brasil, não se constituía campo disciplinar específico, como já havia sido evidenciado nas abordagens de Siqueira (1940), Peregrino Júnior (1941) e Carmo (1942), institucionalizando-se a outra vertente disciplinar: 'higiene e educação alimentar', tal como foi preconizada por Veloso (1940) e Castro (1946). ${ }^{28}$

Finalmente, o estudo do processo de gênese e constituição da educação alimentar põe em evidência a existência de um grupo fundador desse campo, cuja produção científica sobre alimentação e nutrição teve como eixo comum, no período de 1934 a 1939, a formulação e demonstração da tese 'mal de fome e não de raça', procedendo à conexão entre o biológico e o social, mediante uma tendência majoritária de aproximação dos estudos da fisiologia comparada com o método geográfico. No período de 1940 a 1946 esse conhecimento foi reordenado na perspectiva da definição dos marcos conceituais e terminológicos da ciência da nutrição e da definição dos campos disciplinares a ela inerentes, incluindo a educação alimentar, ao tempo em que se intensificava o movimento do referido grupo intelectual em prol da organização e criação das estruturas institucionais necessárias à institucionalização desse campo, fato que se concretizou com a fundação do Instituto Nacional de Nutrição da Universidade do Brasil (1946) como espaço acadêmico no qual a 'higiene e educação alimentar' se autonomizava como campo de ensino e atuação, figurando como matéria do curso de dietistas.

Vale ainda registrar que, na afirmação da identidade coletiva desse grupo e no conjunto da sua produção, teve grande impacto a figura de Pedro Escudero, como assinalavam, em 1946, os Arquivos Brasileiros de Nutrição (Universidade do Brasil, 1946:73):

Os 'Arquivos Brasileiros de Nutrição', noticiando o afastamento do professor Pedro Escudero da sua cátedra universitária, rendem ao ilustre mestre argentino as homenagens mais altas do seu aprêço e tornam público o agradecimento mais cordial dos quantos, no Brasil, têm sido influenciados pela sua Escola de Nutrição.

Os Arquivos Brasileiros de Nutrição foram incorporados ao Instituto de Nutrição da Universidade do Brasil, em 1946, como segue: "Extinto, porém,

${ }^{28}$ Foram professores desse primeiro curso de dietistas do Instituto Nacional de Nutrição: Josué de Castro, José Farias Góes Sobrinho, Rubens de Siqueira, J. P. Lopes Pontes, Clementino Fraga Filho, Lincoln de Freitas Filho, J. J. Barbosa, Sylvio Soares de Mendonça, Pedro Borges, Hélio de Souza Luz, Isaac Waissman, Thereza Velasco Kopp, Firmina Santana, Lieselotte Hoeschl, Noemia Perin de Góes, Jacyra Carvalho e Mirtila de Araújo Carvalho (Associaçāo BRASILEIRA DE Nutrição, 1991). 
com o término da Guerra, o Serviço Técnico da Alimentação Nacional, como setor que era da Coordenação de Mobilização Econômica, não foi mais possível a publicação dos Arquivos Brasileiros de Nutrição. Agora, após um período de latência, volvem os Arquivos Brasileiros de Nutrição a atuar no espaço cultural da sua especialidade, idênticos, tanto na feitura material como nos propósitos de atividade científica, delineados no editorial de apresentação do seu primeiro número. Como órgão oficial do Instituto da Universidade do Brasil, reencetam os Arquivos Brasileiros de Nutrição a marcha interrompida, esperando os que têm deles agora a responsabilidade poderem mantê-los no mesmo nível superior de cultura" (Universidade do Brasil, 1946).

Em síntese, as evidências atestam a validade da hipótese inicial formulada nesse estudo de que: essa modalidade de conhecimento, publicada em livro no período de 1934 a 1946, caracterizou o conjunto da produção pioneira da nutrição no País, delineando a base cognitiva da educação alimentar à luz da conexão entre o biológico e o social. Isso implica a reflexão, em última instância, sobre os limites e avanços do método geográfico como suporte teórico-metodológico da higiene e educação alimentar no Brasil, no horizonte da duração do processo de gênese e constituição da educação alimentar. 